\title{
Local level authorities and local action in Greater Khartoum, Sudan [Arabic]
}

Gamal M. Hamid

Follow this and additional works at: https://knowledgecommons.popcouncil.org/departments_sbsr-pgy How does access to this work benefit you? Let us know!

\section{Recommended Citation}

Hamid, Gamal M. 2000. "Local level authorities and local action in Greater Khartoum, Sudan," MEAwards Regional Paper [in Arabic]. Cairo: Population Council. 

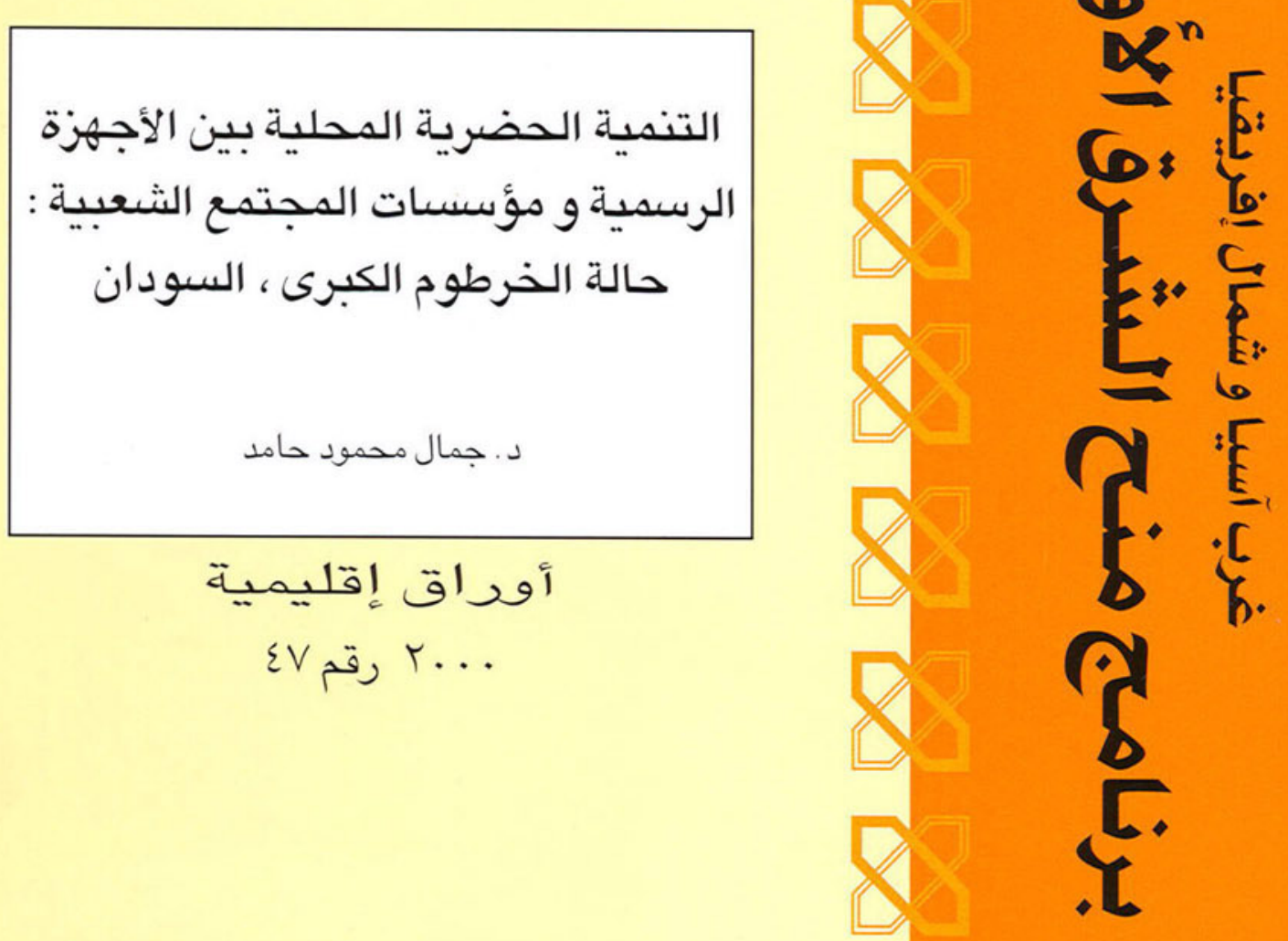

|) مجلس السكان الدولى 


\section{Local Level Authorities and}

Local Action in Greater Khartoum, Sudan
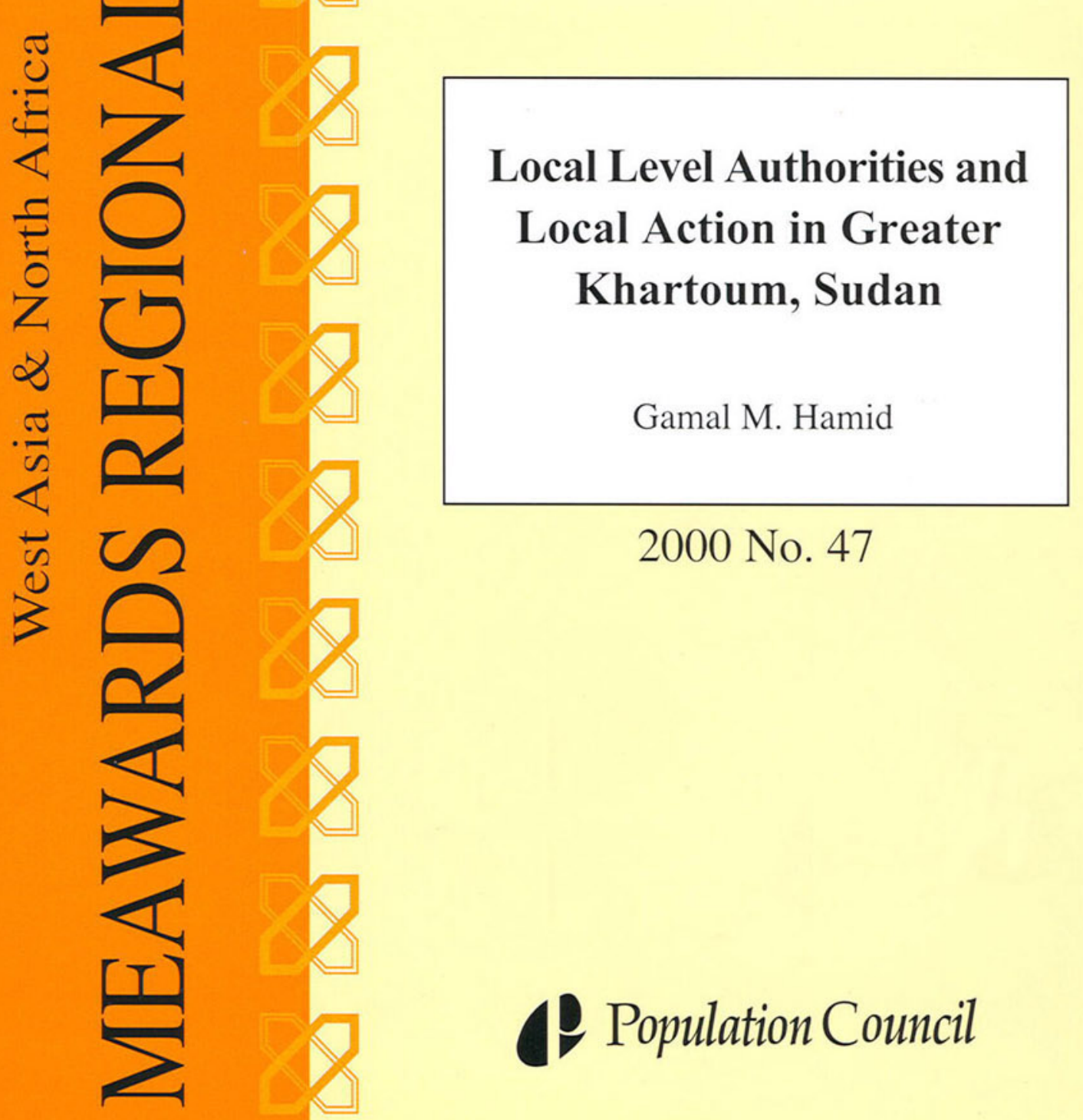

(P) Population Council 


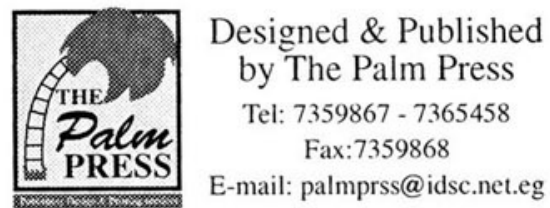




\section{التنميسـة الحصريسيسة البحليسـيسة

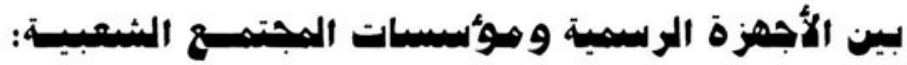

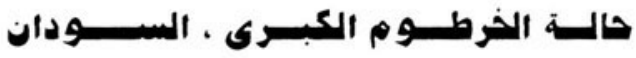

تأليـف

د. جمــال محمــود حـــامد

أستاذ العمارة والتخطيط العمراني المساعد جامعة الخرطوم 


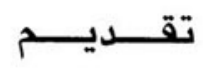

تأتي هذه الإصدارة ضمن مبادرة بحثية قام بها برنامج منح الشرق الأوسط في السكان والعلوم

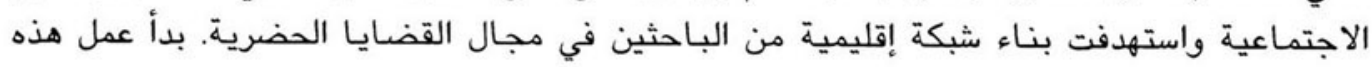

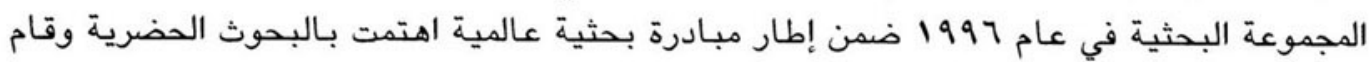

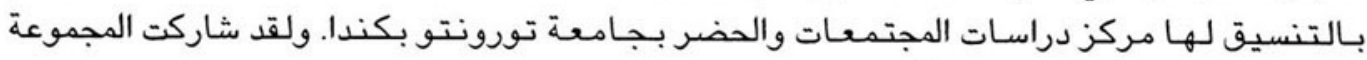

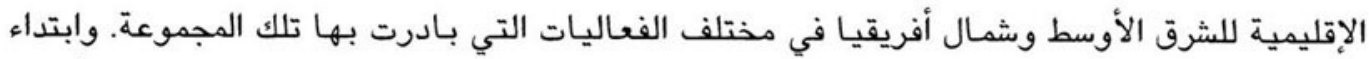

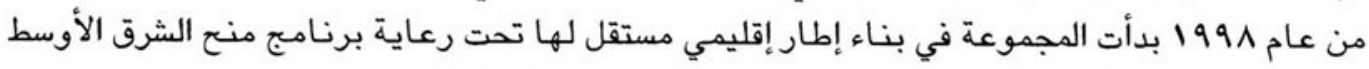

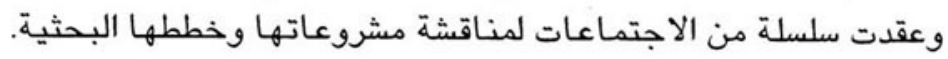

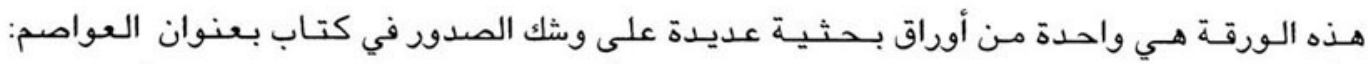

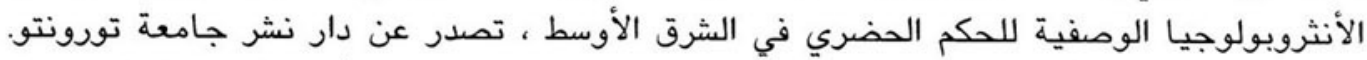

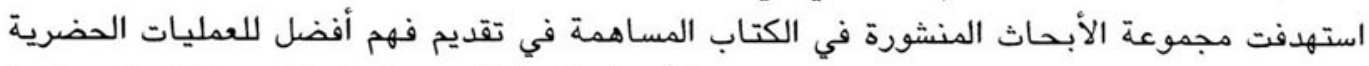

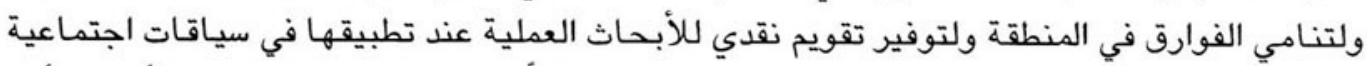

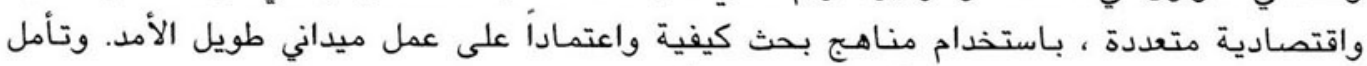

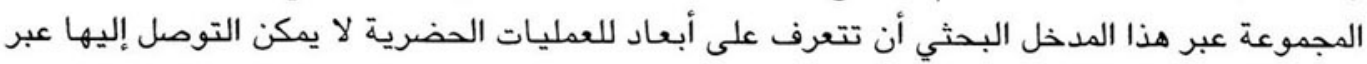
مداخل أخرى. - مبرع.

ولقد هدفت المبادرة البحثية إلى توفير إطار يجمع الباحثين الشباب في المنطقة ويوفر سبل التعاون

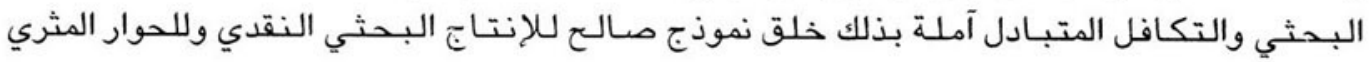
للسياسات ولبناء قدرات شباب الباحثين في المنطقة.

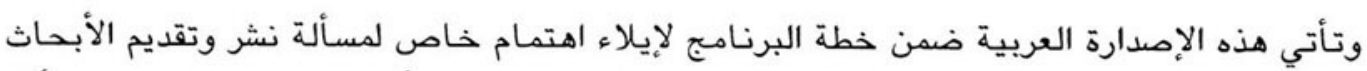

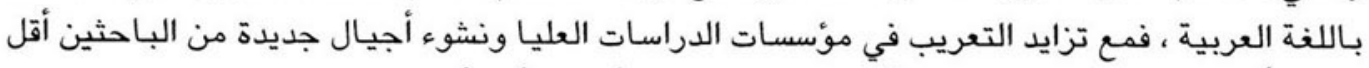

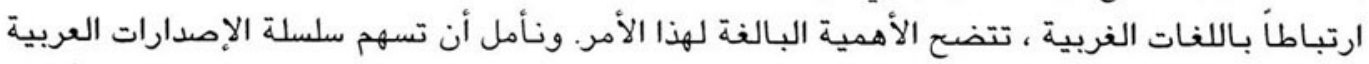

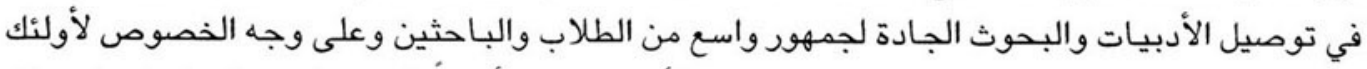

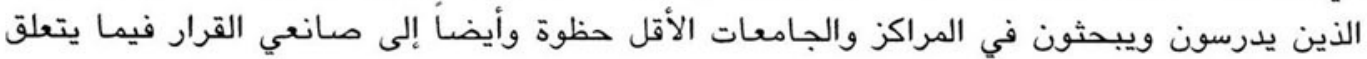
بالدراسات السكانية.

$$
\begin{aligned}
& \text { د. ابراهيــــم النــــور } \\
& \text { مدير برنامج منح الشرق الأوسط } \\
& \text { القاهرة ديسمبر .... }
\end{aligned}
$$


Printed by The Palm Press

34 El Mansour Mohamed Street, Zamalek, 11211 Cairo, Egypt

Tel: (20-2 ) 735 9867, 7365458

Fax: (20-2) 7359868 


\section{شكــــر وعـرفــــان}

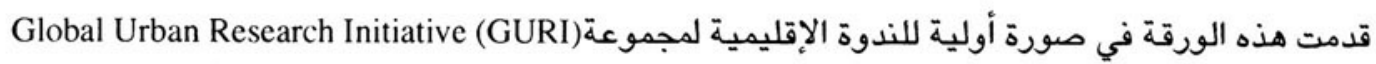

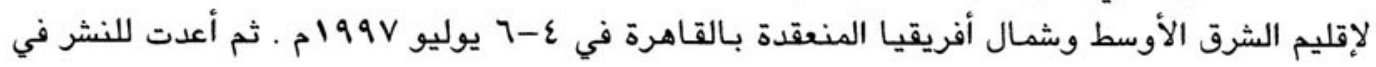

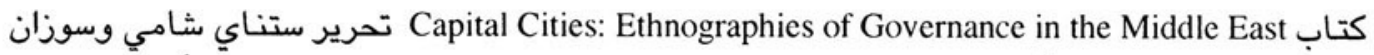

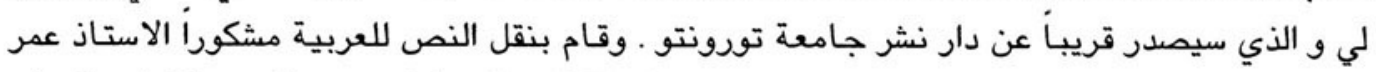

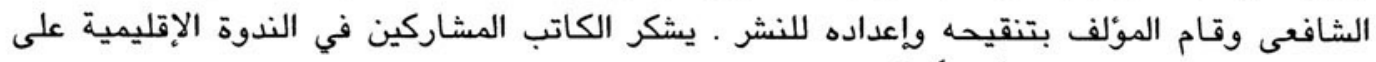

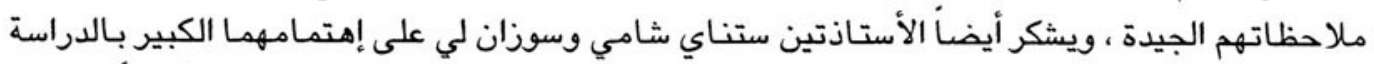

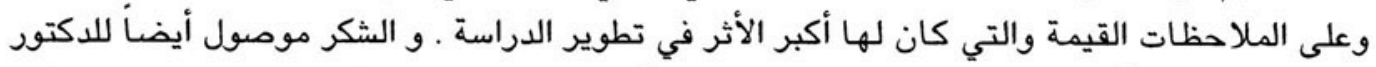

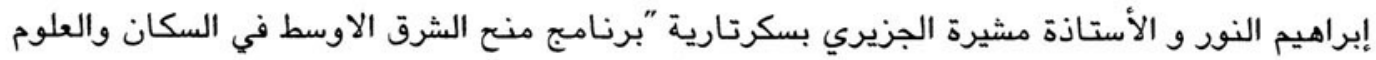

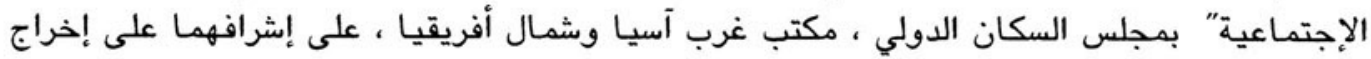
الدراسة في صورتها الحالية. 


\section{مختصر الدراسة}

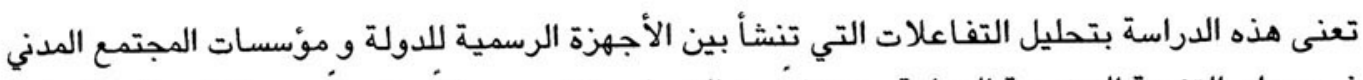

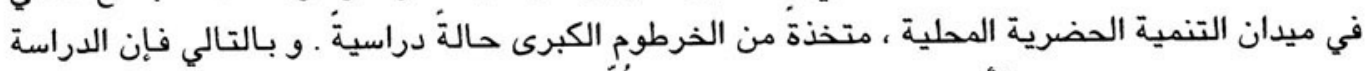

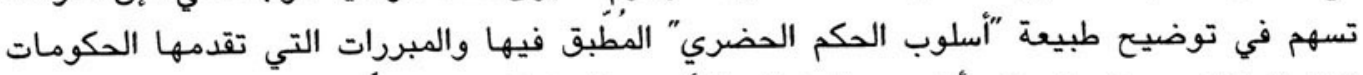

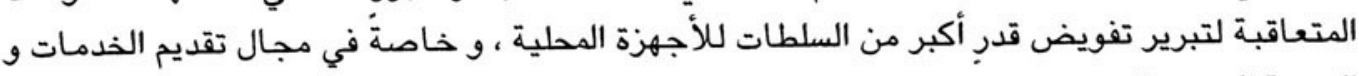
التنمية الحضرية .

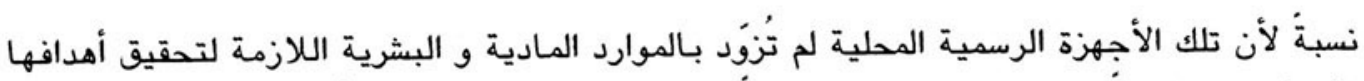

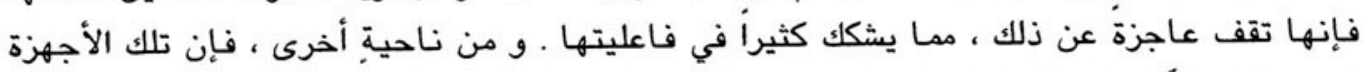

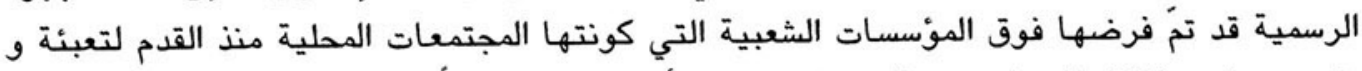

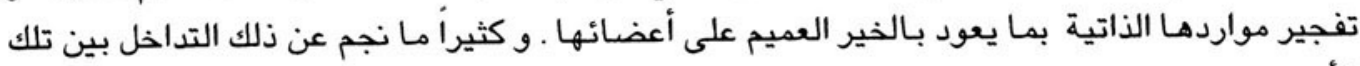

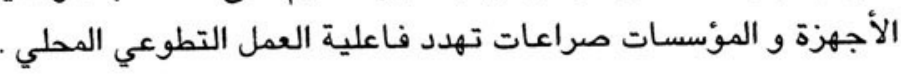

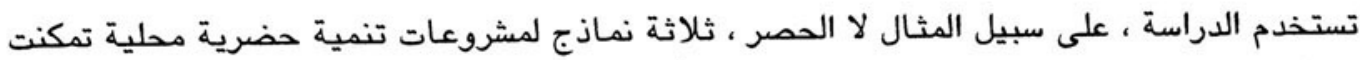

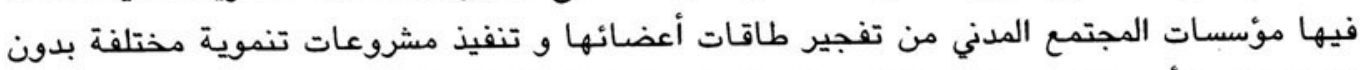

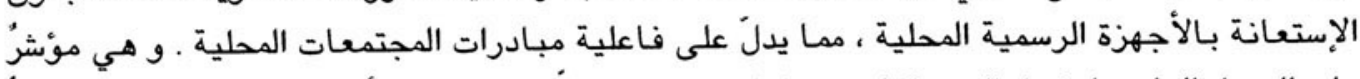

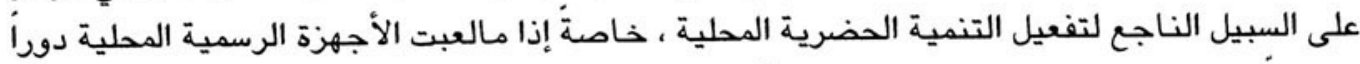

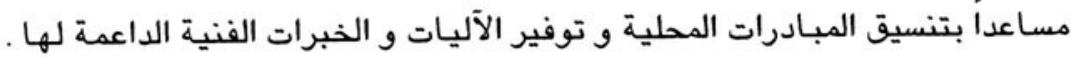




\section{(1الفهرس}

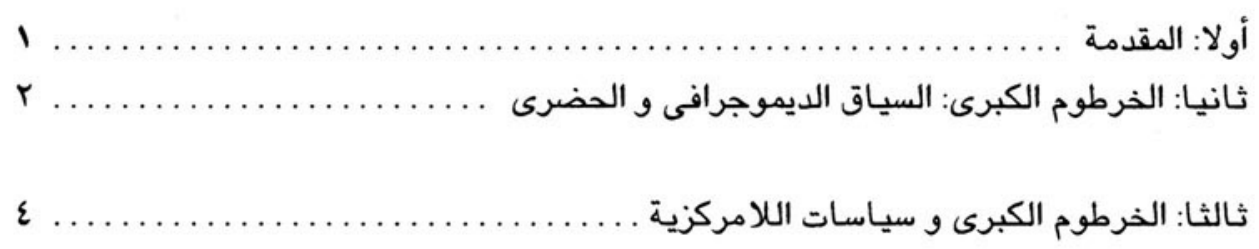

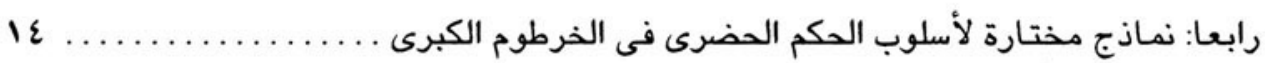

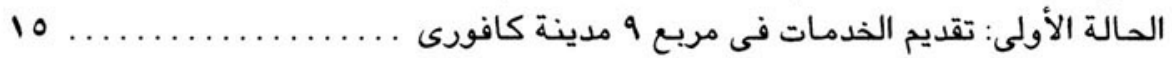

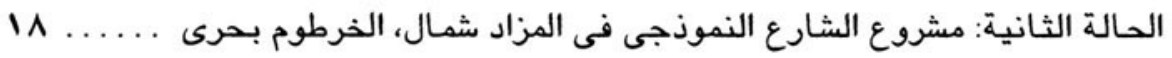

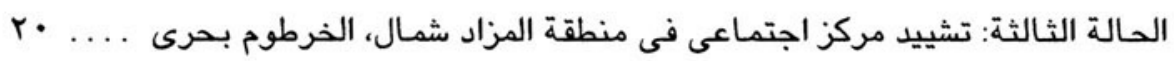

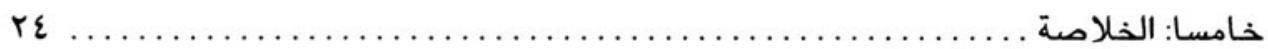

rv

الهوامش 
يختلف مفهوم "أسلوب الحكم الحضري" (urban governance) إختلافأ كبيراً عن مفهوم "الحكومة

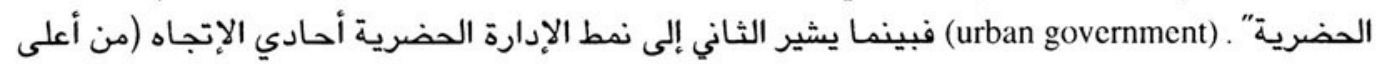

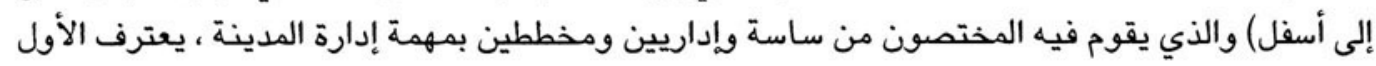

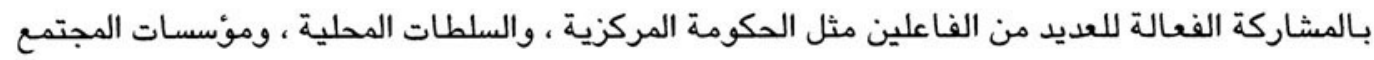

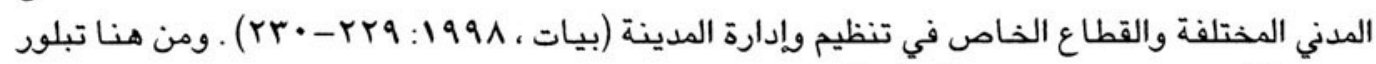

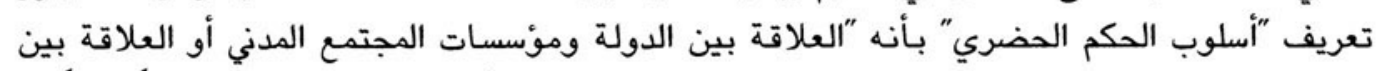

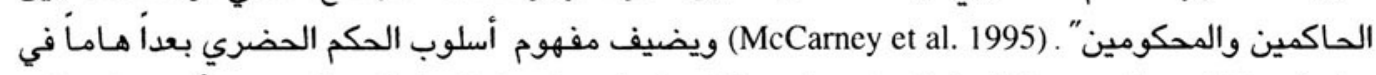

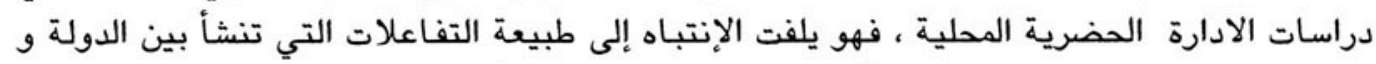

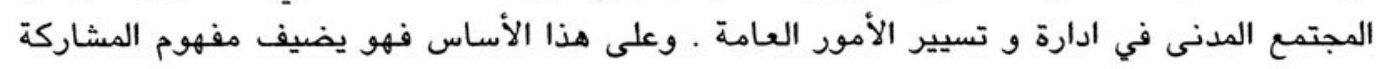

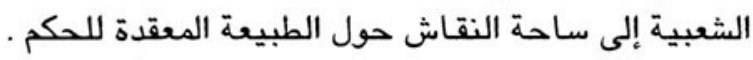

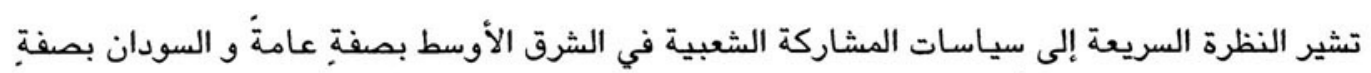

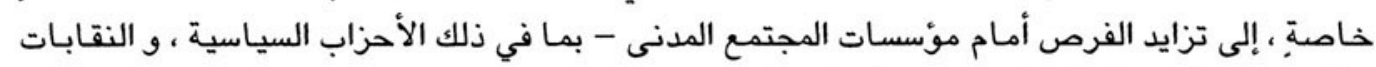

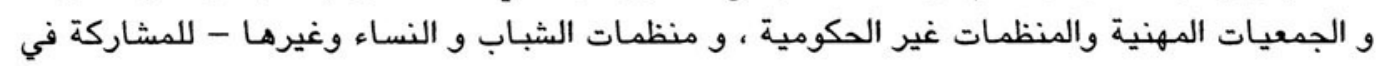

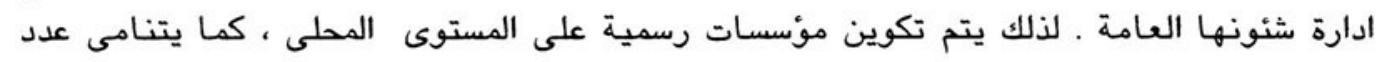

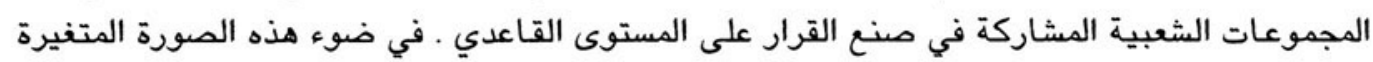

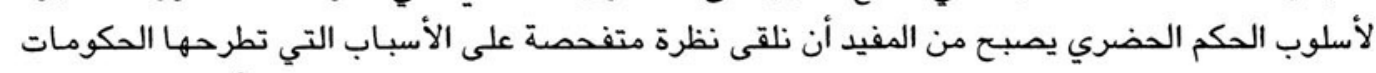

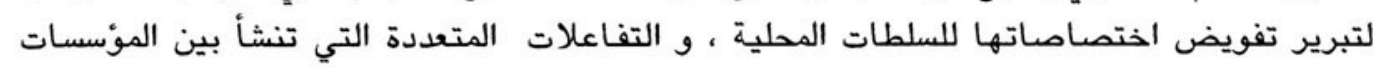

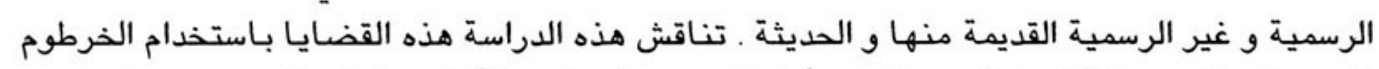
الكبرى كمثال و حالة للدراسة ، وذلك من أجل التعرف على طبيعة أسلوب الحكم الحضرى في السرة السودان.

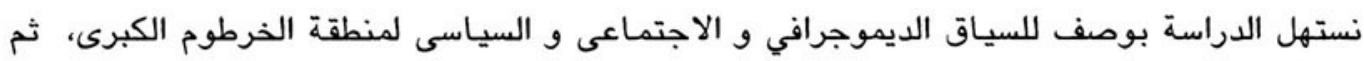

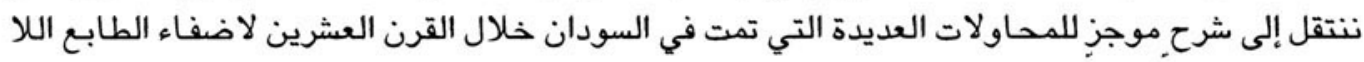

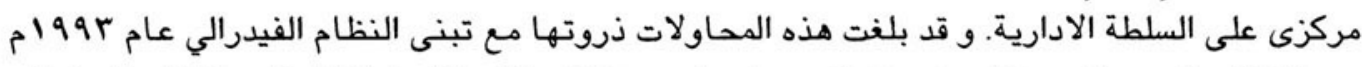

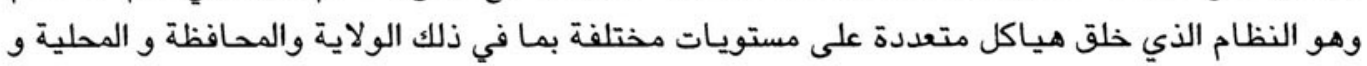

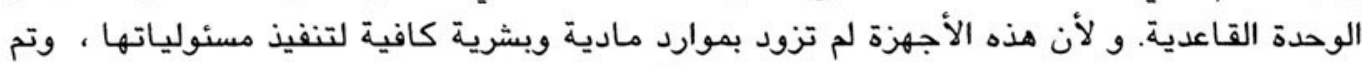

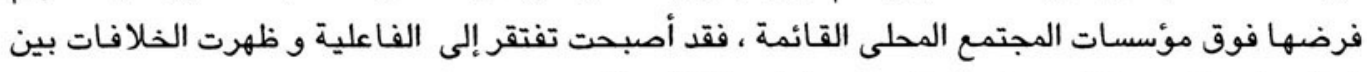
المؤسسات الرسمية الجديدة و المؤسسات الشعبية القديمة. 
و تستخدم هذه الدراسة ثلاث حالات لتوضيح هذه النقاط و البحث في العلاقات القائمة أو الغائبة بين

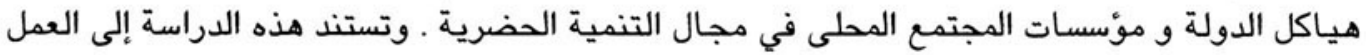

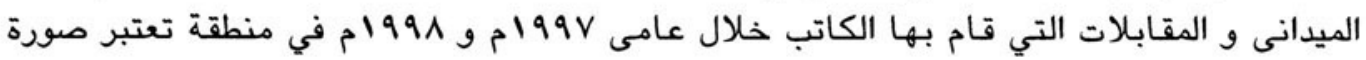

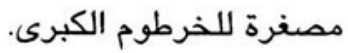

\section{ثانياً: الخرطـوم الكبــرى: السيـاق الديموجرافي و الحضـري}

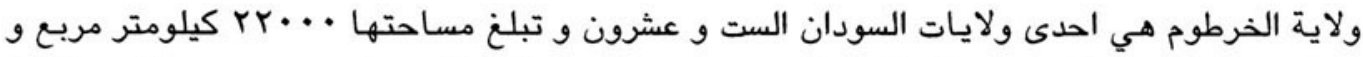

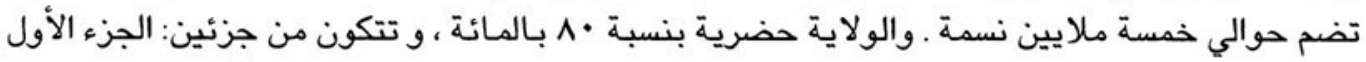

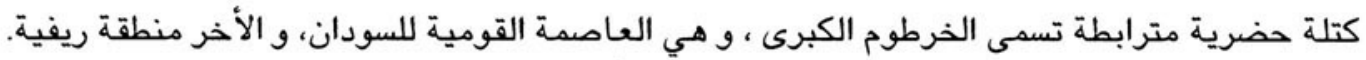

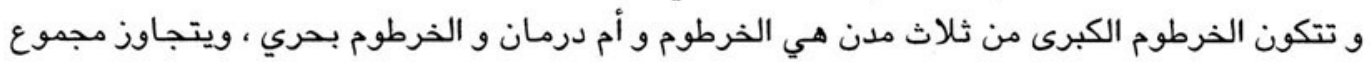

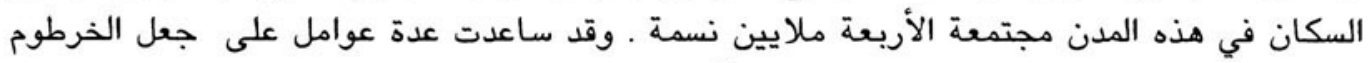

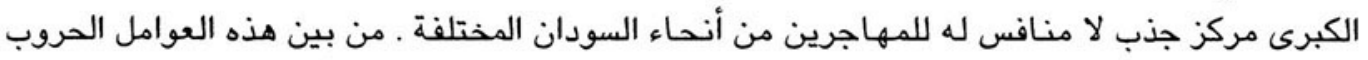

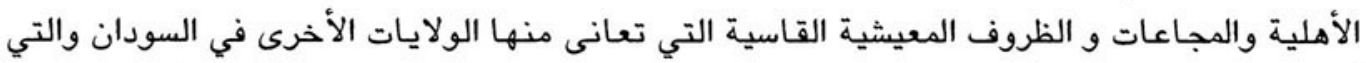

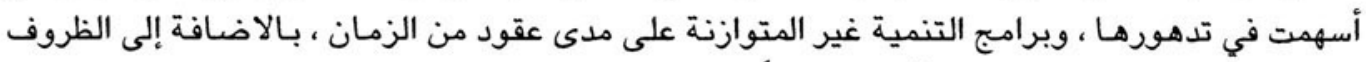

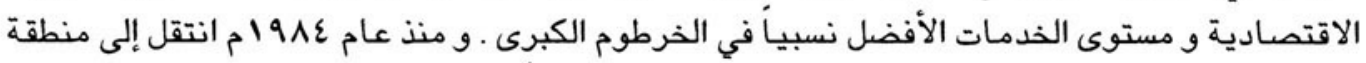

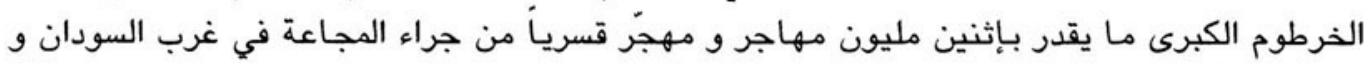

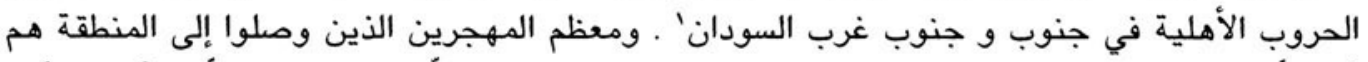

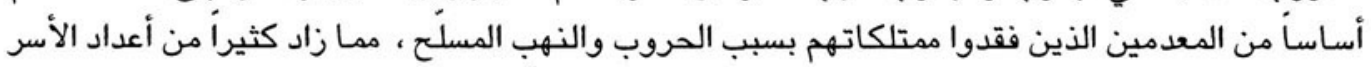

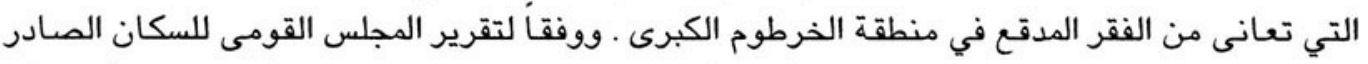

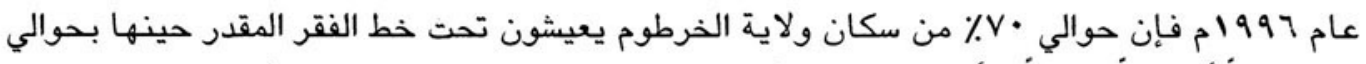

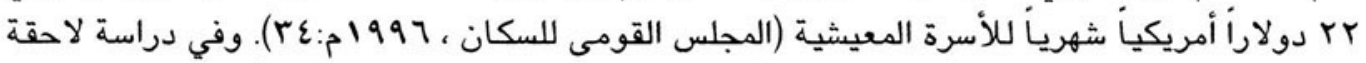

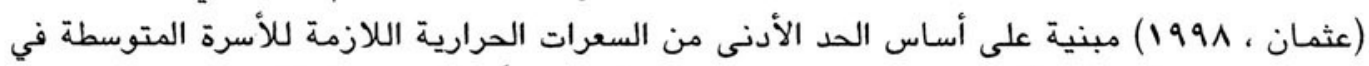

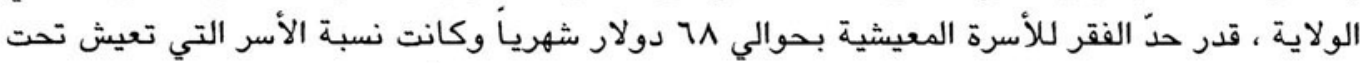

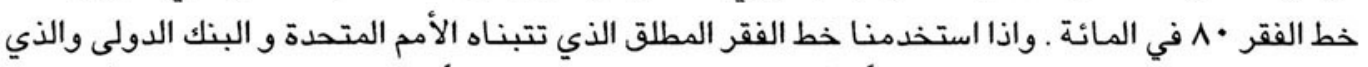

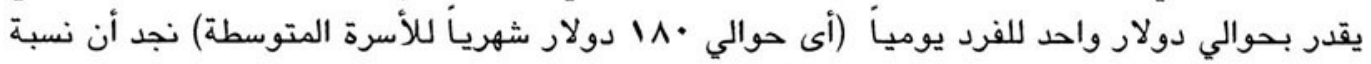

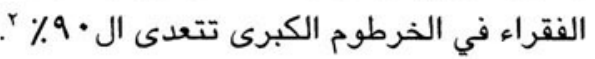

مرَت منطقة الخرطوم الكبرى بتغيرات سريعة في أوضاعها الاجتماعية والاقتصادية و الديموجرافية .

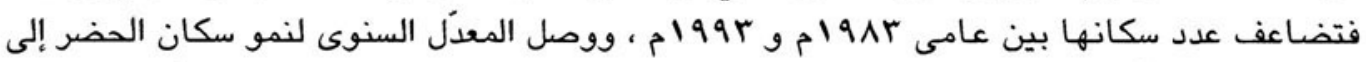

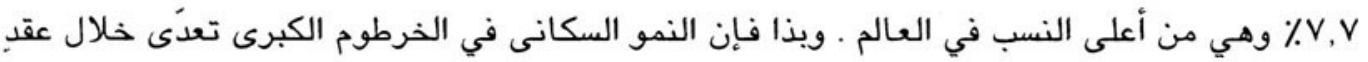

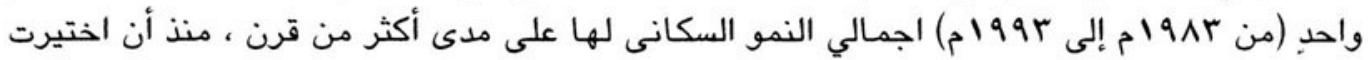




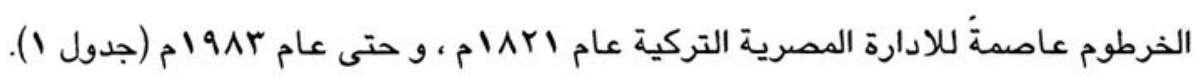
جدول 1 : النمو السكانى في الخرطوم الكبرى

\begin{tabular}{|c|c|c|c|c|}
\hline$h^{199 r}$ & 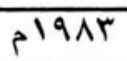 & $b^{19 V r}$ & 1900 & \\
\hline$r, \wedge r t$ & $1, r \varepsilon r$ & $\overline{v \wedge r}$ & rרI & السكان (بالألف) \\
\hline$v, v$ & 0,0 & $7, r$ & - & متوسط النمو السنوى للسكان (\%) \\
\hline$\Pi, \varepsilon$ & 7,0 & 0,0 & $r, 0$ & نسبة سكان الخرطوم الكبرى لسكان السودان (٪) \\
\hline
\end{tabular}

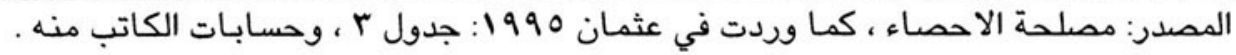

ومنذ ذلك الحين تناقص هذا النمو السكانى الكبير تدريجياً ، الا أن المدينة لاتزال تعانى من آثاره

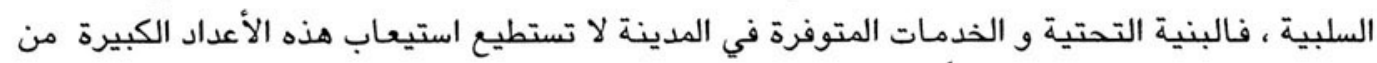

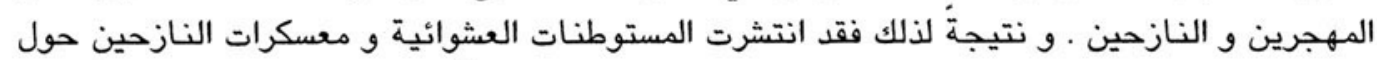

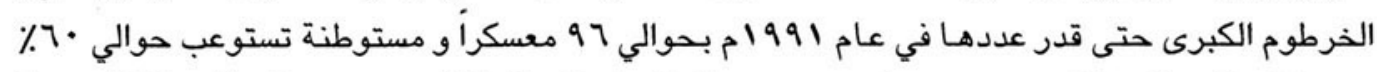

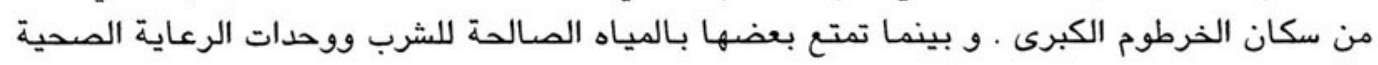

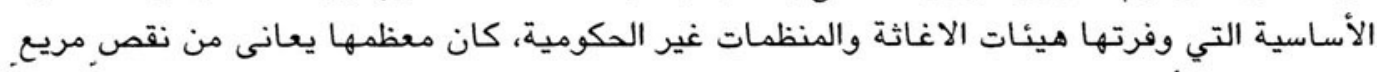

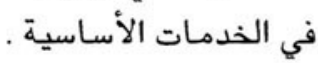

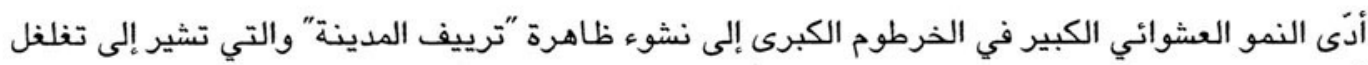

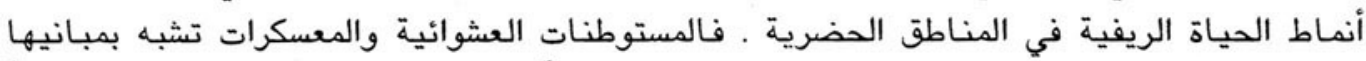

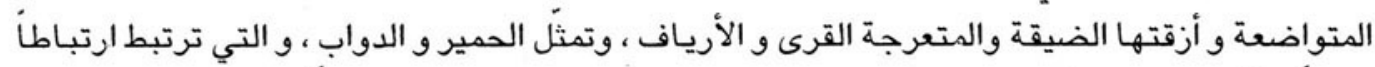

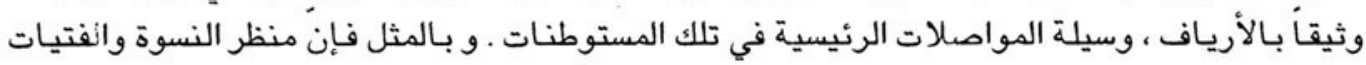

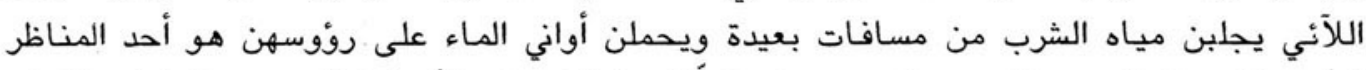

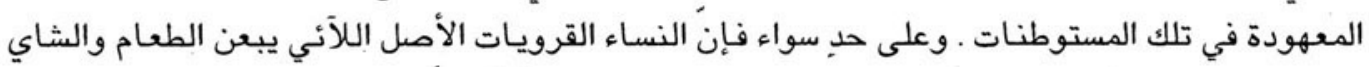

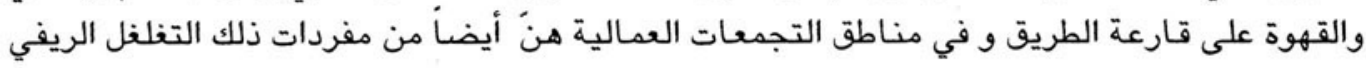
في المدينة.

وفي عام r99 199 تبنت الحكومة خارطة هيكلية للخرطوم الكبرى تضمنت خطة لترقية تلك المستوطنات

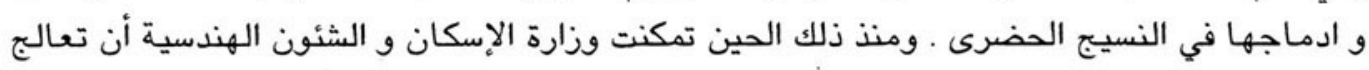

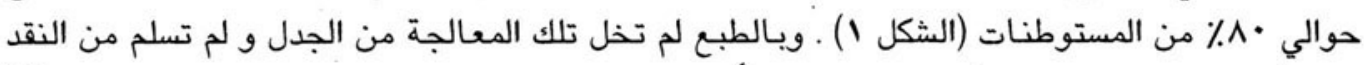

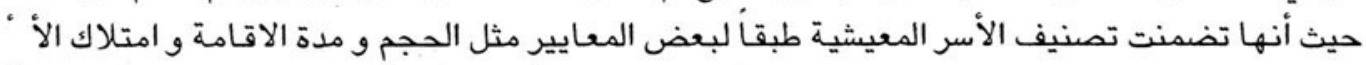

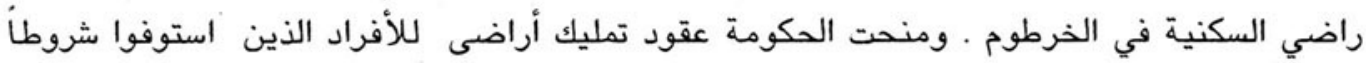




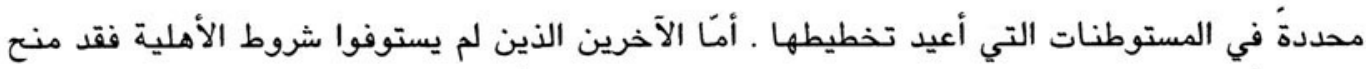

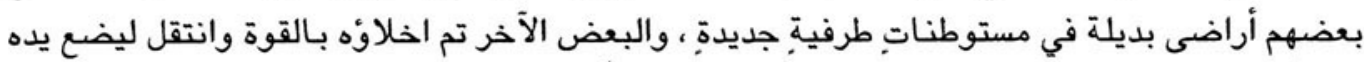

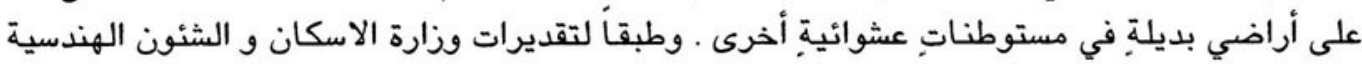

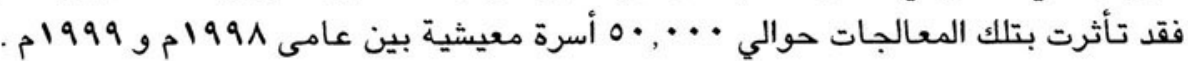

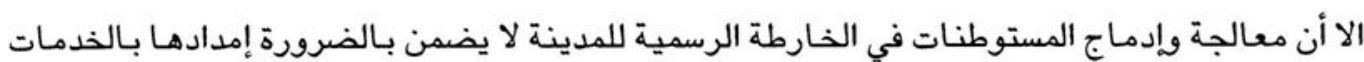

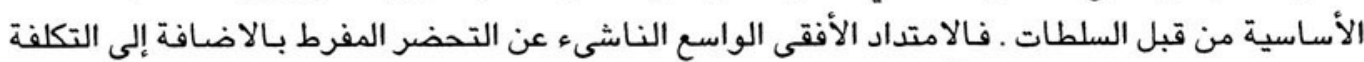

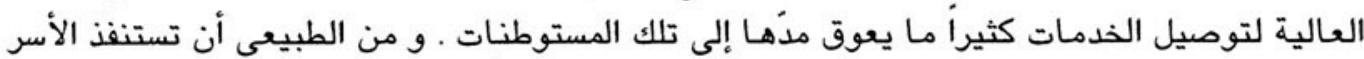

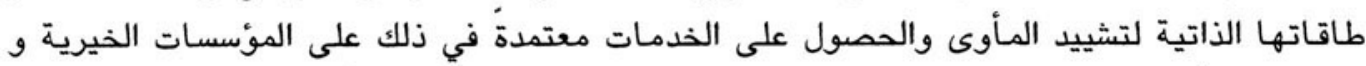

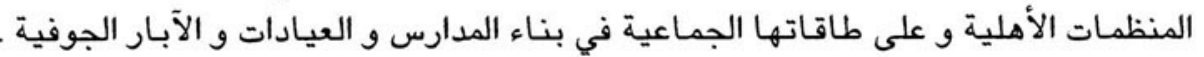

\section{ثالثاً: الخرطوم الكبرى و سيـاسـات اللا مركزيــــة}

تزامن النمو الحضري المفرط في منطقة الخرطوم الكبرى مع تفاقم الصعويات الاقتصادية ـ و بصفة

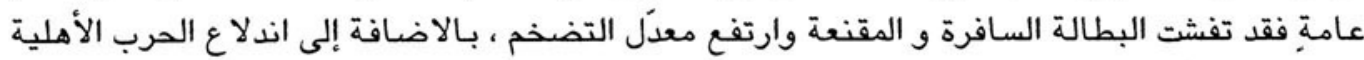

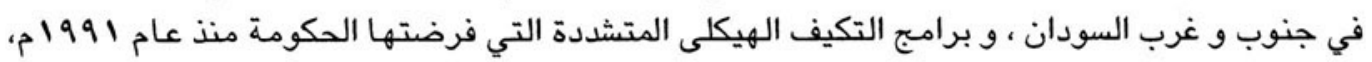

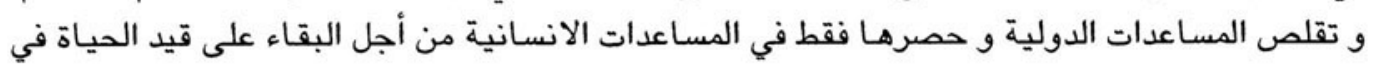
المناطق المتضررة بالحرب .

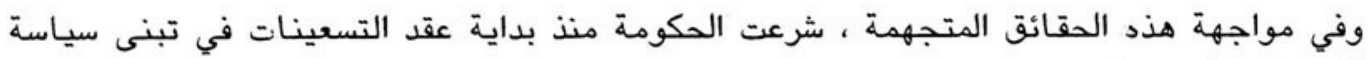

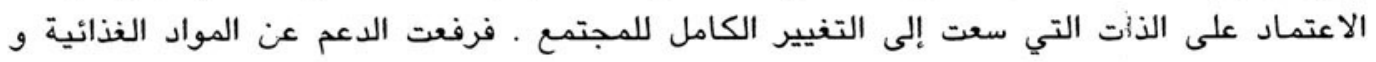

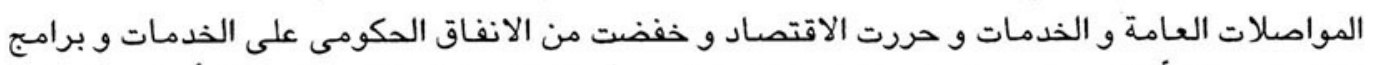

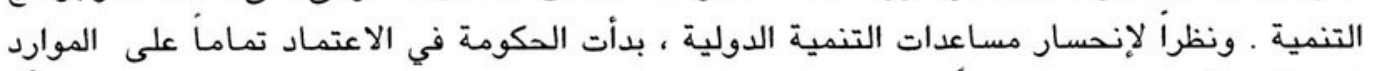

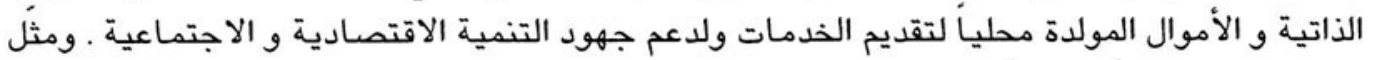

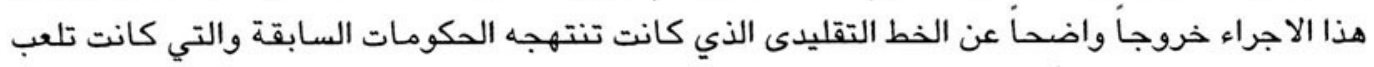

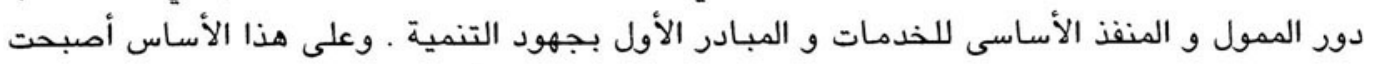

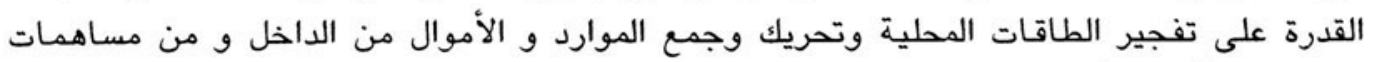

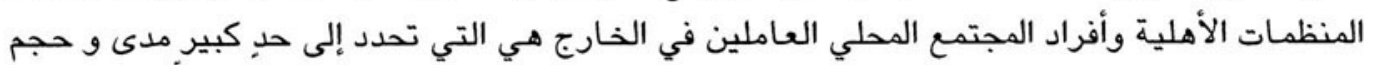

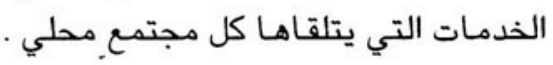


بالاضافة إلى ذلك ، نفذت الحكومة برنامجاً طموحاً يهدف إلى تفعيل نظام الحكم اللامركزي من أجل

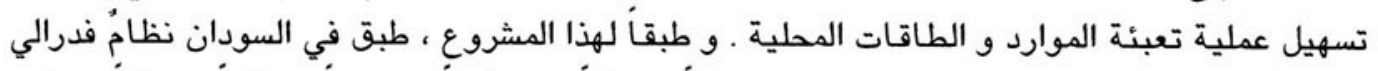

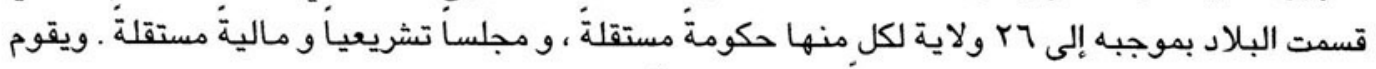

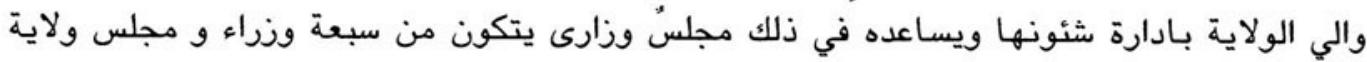

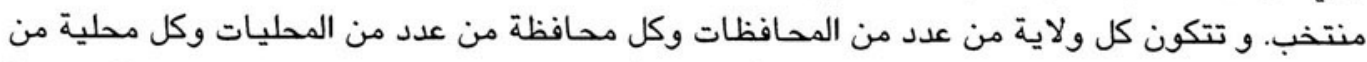

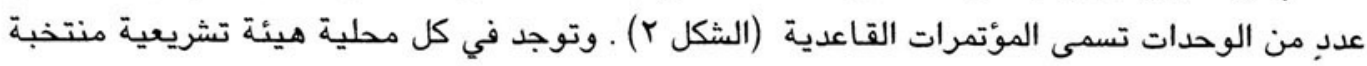

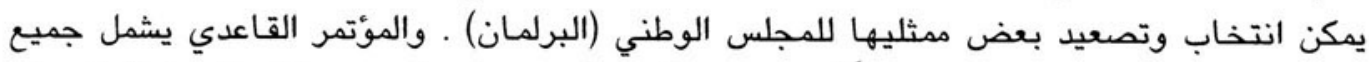

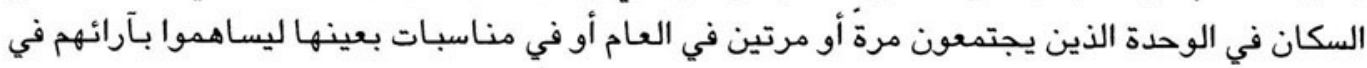

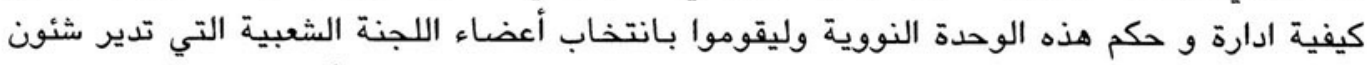

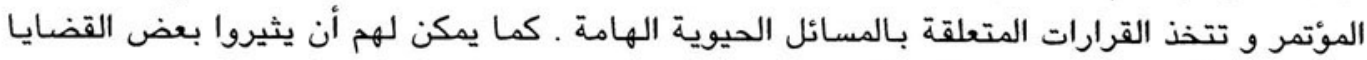

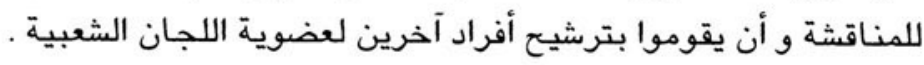

وتنقسم ولاية الخرطوم إلى سبع محافظات مقسمة بدورهـا إلى حr محلية (الجدول r). وتنقسم المحليات

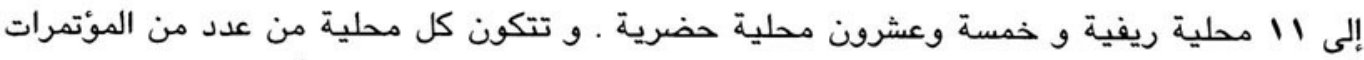

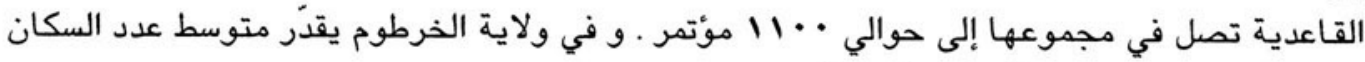

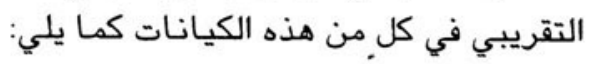

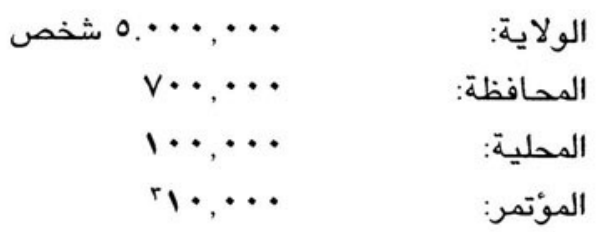




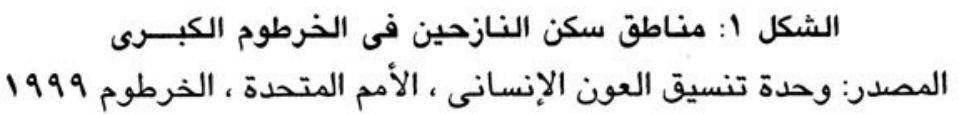

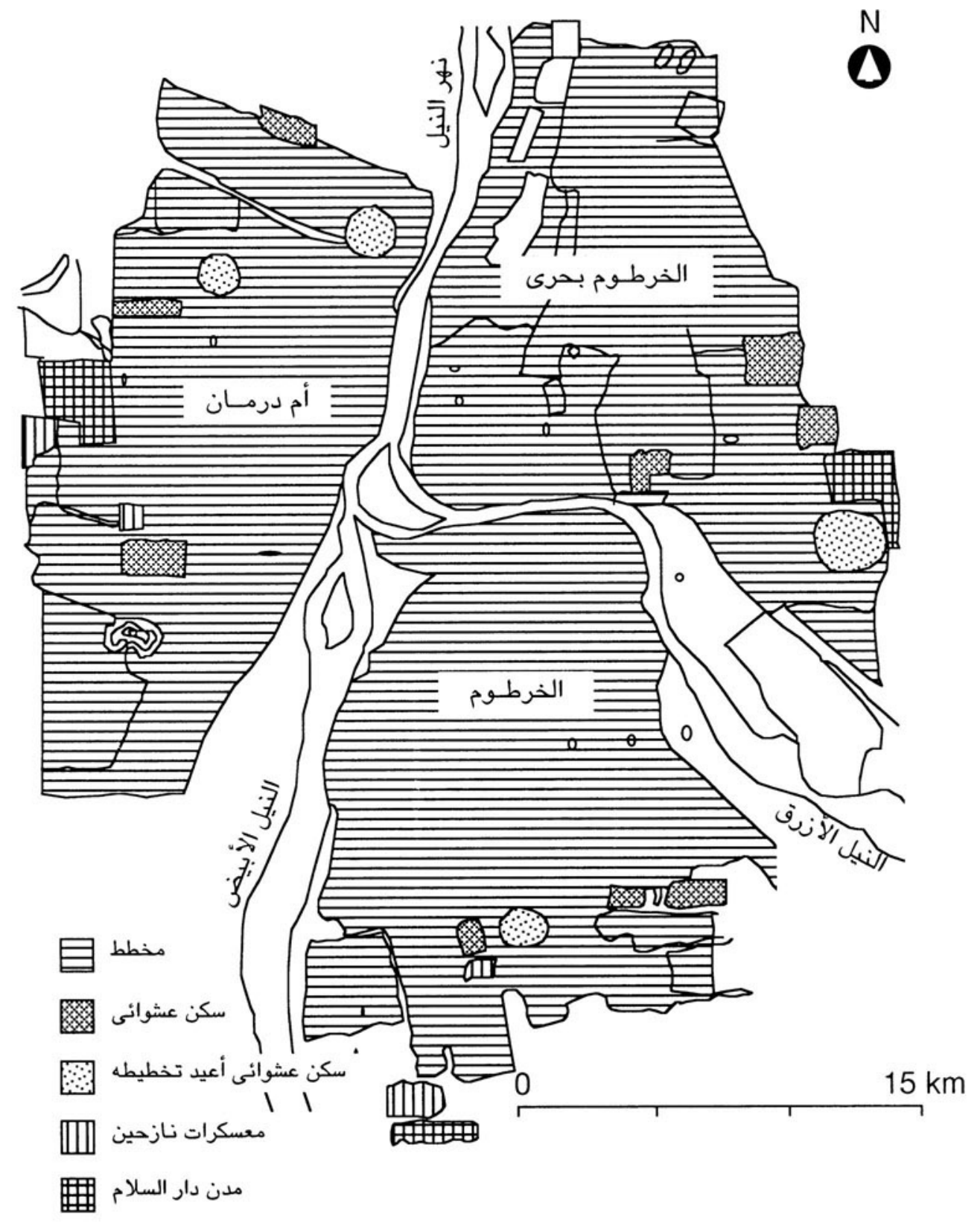


الشكل r: الهيكل الإدارى لكل ولاية من الولايات
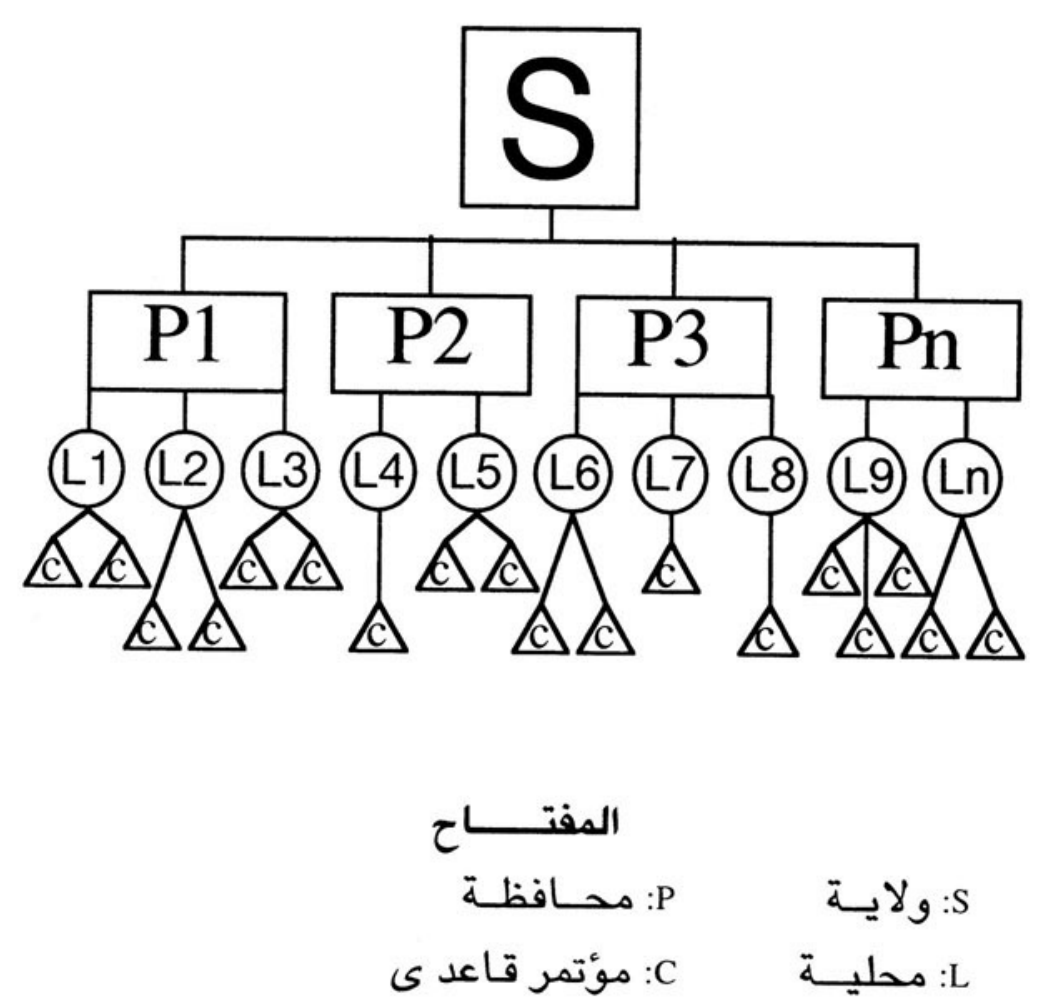


\begin{tabular}{|c|c|}
\hline المحليـــــــات & المحسافظة \\
\hline سوبـا و الجريف ـ ـ الشجرة ـ الخرطوم غرب ـ الخرطوم شرق ـ الخرطوم ـ الشهداء ـ & الخرطـــــوم \\
\hline 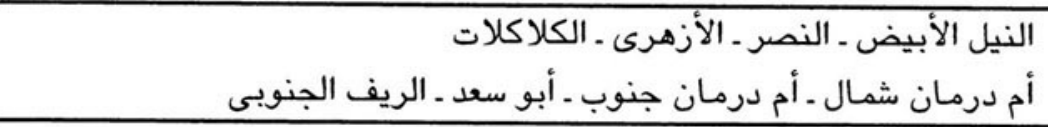 & أم دبل اوليـاء \\
\hline الثورات ـ كررى ـ الريف الشمالى & 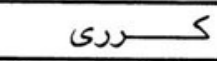 \\
\hline الأمير ـ البقعة ـ السلام ـ الريف الغربى & أمبـــــــدة \\
\hline الخرطوم بحري ـ عمر المختار ـ الحلفاية ـ الدروشاب ـ السليت ـ الريف الشمالى & 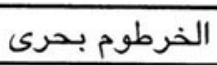 \\
\hline 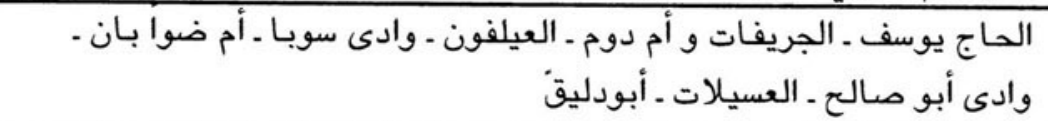 & شـــرق النيـــلـل \\
\hline
\end{tabular}

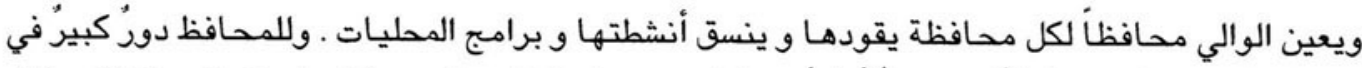

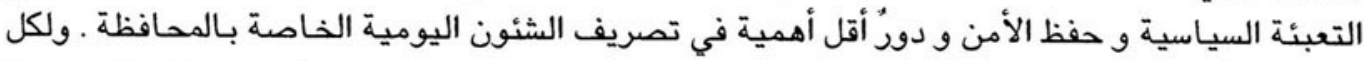

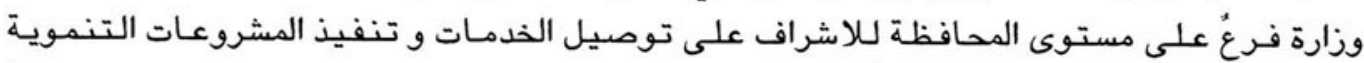

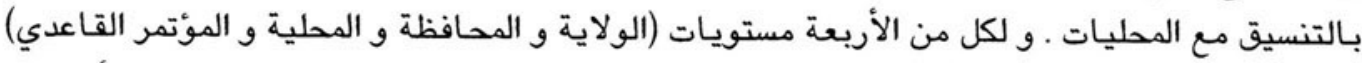

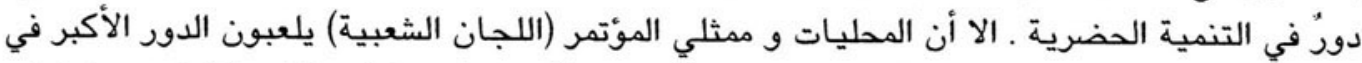

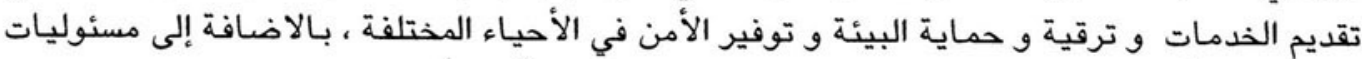

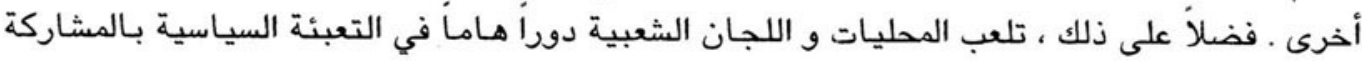

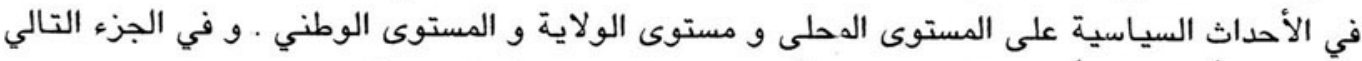

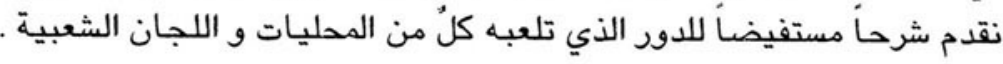

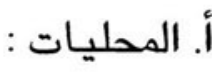

للمحلية ذراعان متكاملان هما الجهاز التنفيذى و المجلس التشريعي المنتخب من قبل سكان المحلية .

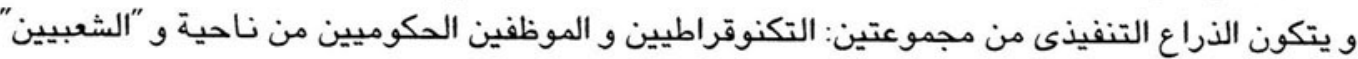

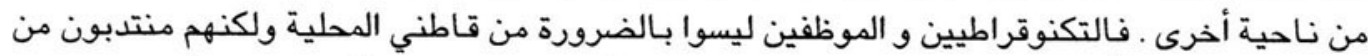

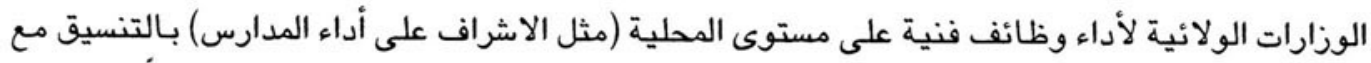

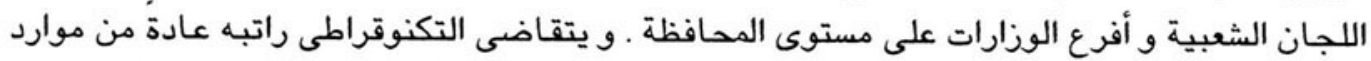

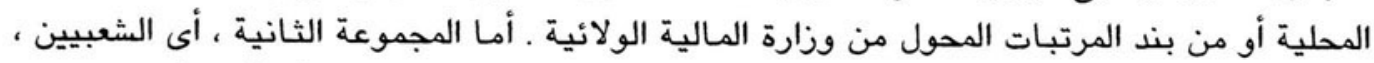

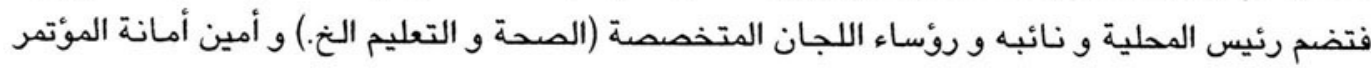


الوطنى (الحزب الحاكم) على مستوى المحلية ـ وهذه المجموعة المنتخبة من قبل مجلس المحلية هي التي

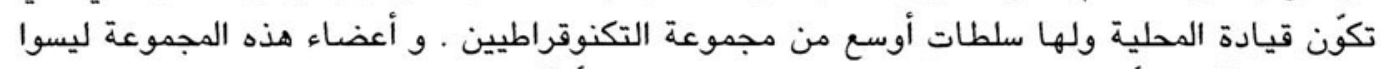

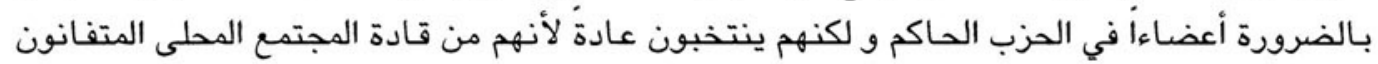

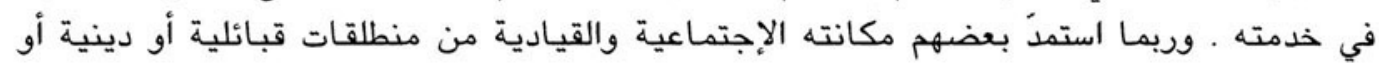

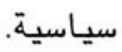

أما مسئوليات المحليات فهي كالآتــى: - المي ا 1 . سياسية: تعبئة المواطنين لأهداف سياسية متنوعة .

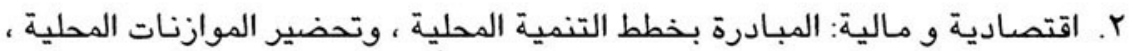

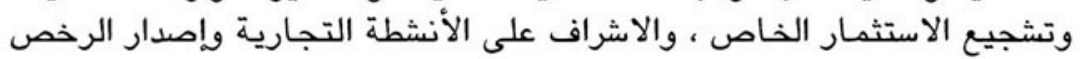

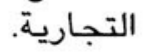

r. الأمن و النظام العأم: المحافظة على القانون و النظام ، و محاربة أشكال الفساد المختلفة و التوسط لحل الخلافات المحلية .

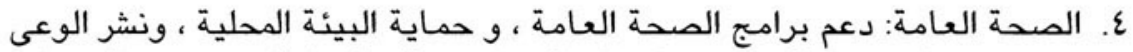

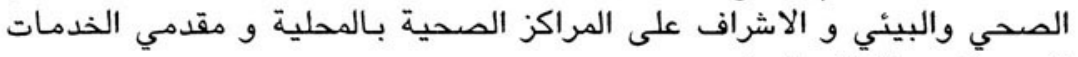

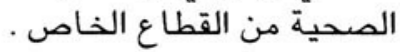

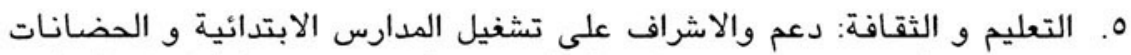

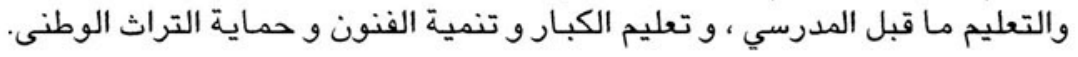

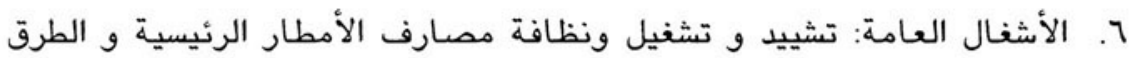

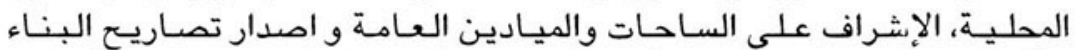

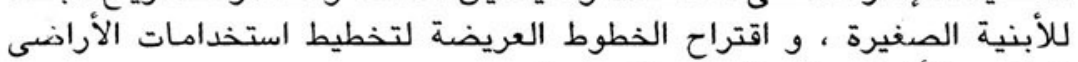

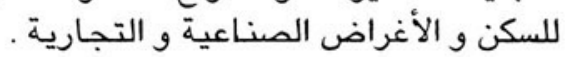

V. العمل الاجتماعى: تنفيذ برامج الرعاية الإجتماعية ومحاربة الفقر و جمع و توزيع أموال الزكاة على المستحقين.

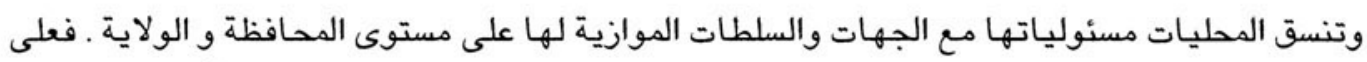

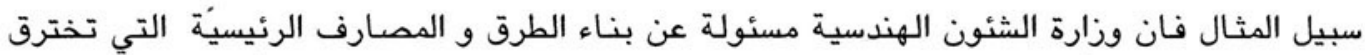

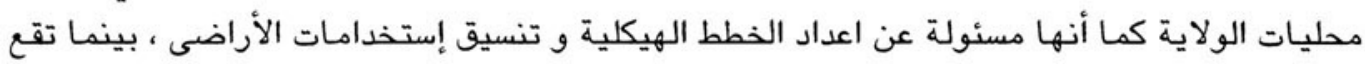

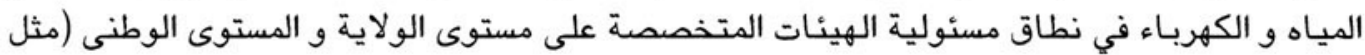
هيئة مياه المدن والهيئة القومية للكهرباء). 


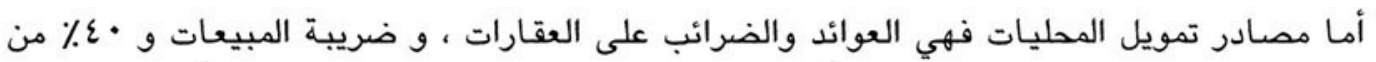

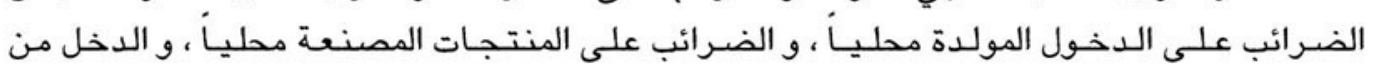

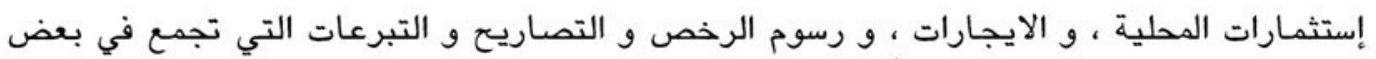

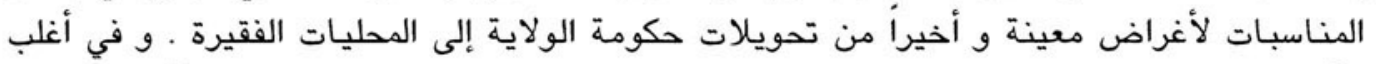

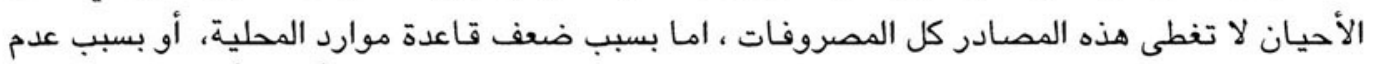

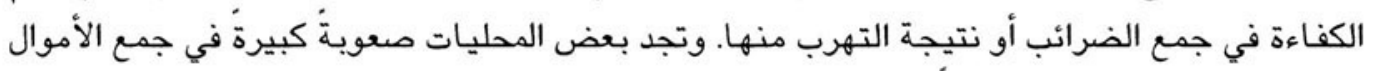

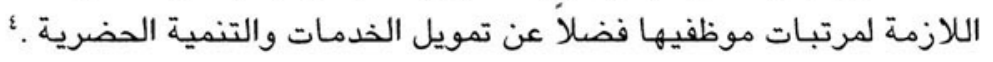

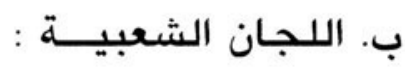

تشكَ اللجان الشعبية على مستوى المؤتمر القاعدي أو المنطقة السكنية و تتكون من ممثلين ينتخبهم

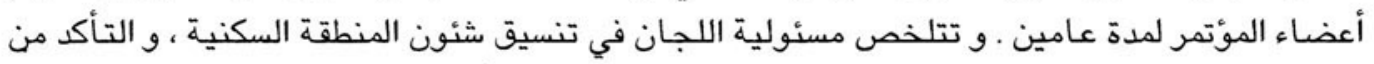

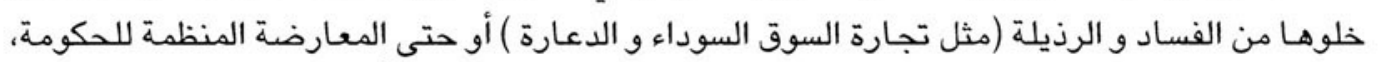

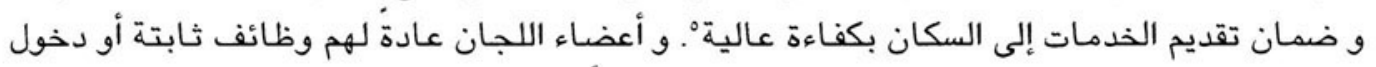

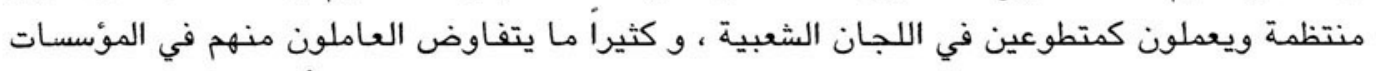

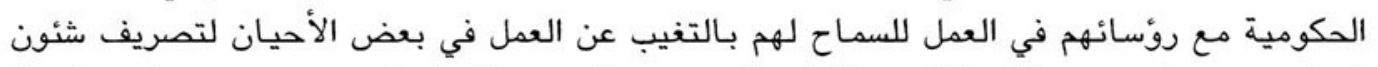

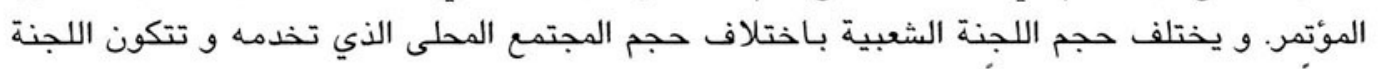

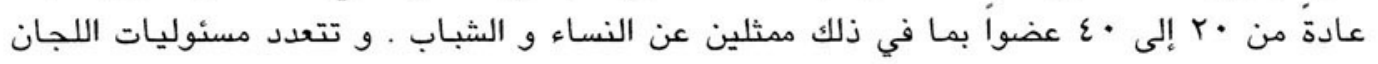

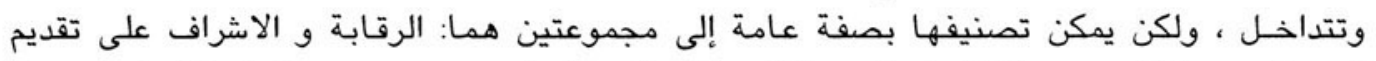

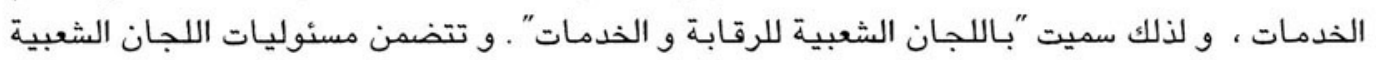

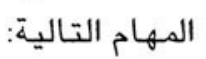

I. ضمان تدفق السلع الإبتراتيجية مثل الخبز و المنتجات الددعومة مثل السكر'. r r r أشجيع مشاركة المجتمع المحلى في الأحداث السياسية.

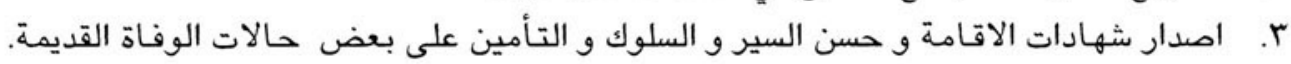

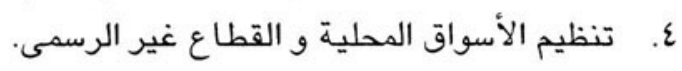
0. مراقبة المواصلات العامة.

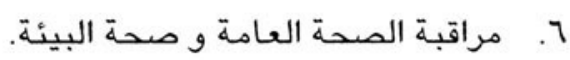

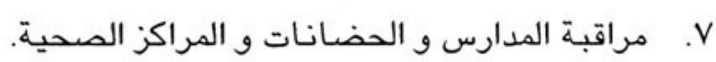

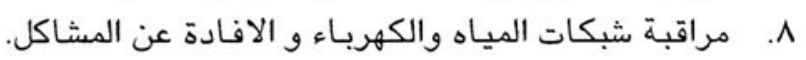

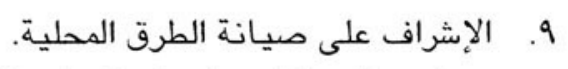
• 1. مساعدة الشرطة في المحافظة على الأمن العام و محاربة الجريمة و الفساد. 
II II التنيم ودعم العمل التطوعي وحملات النفير. r r ا. جلب الزكاة من "صندوق الزكاة" الولائي و توزيعها على الفقراء.

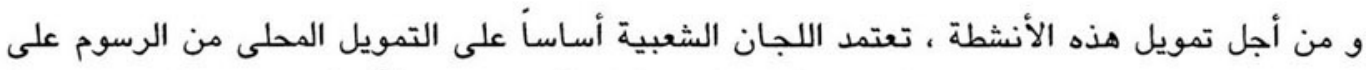

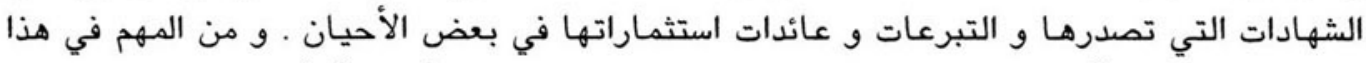

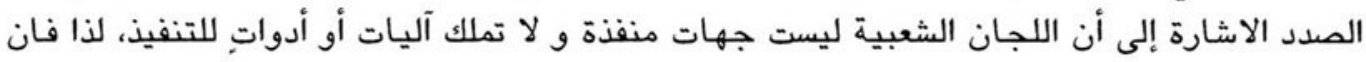

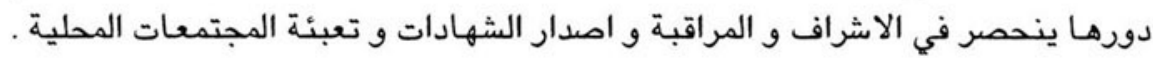

إن هذا النظام المعقَ للامركزية هو آخر حلقة في سلسلة التجارب التي طُبقت في السودان خلال القرن

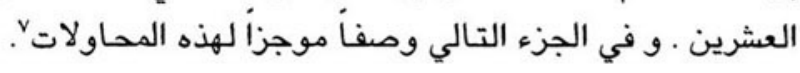

تحوطأ للمصاعب الكامنة في حكم بلد مترامى الأطراف مثل السودان^ ، فوضض الإستعمار البريطاني

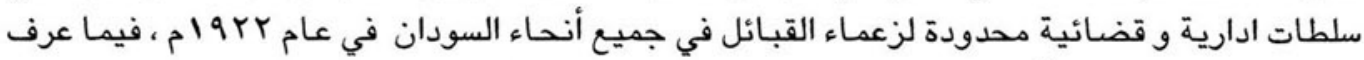

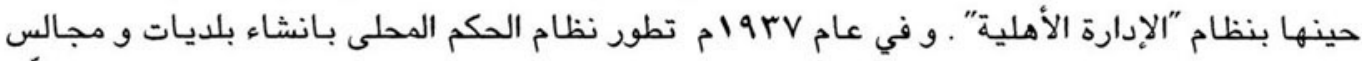

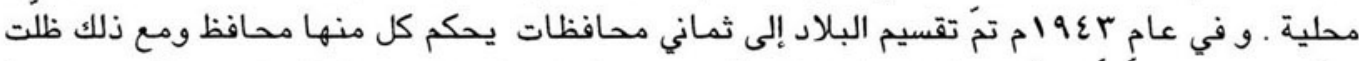

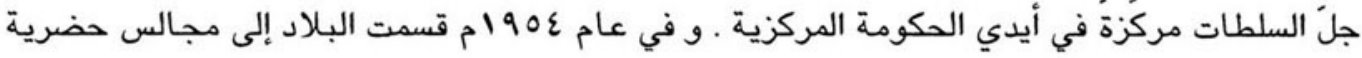

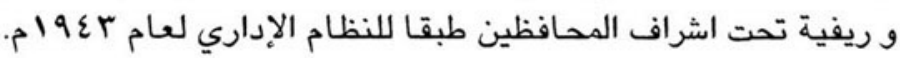

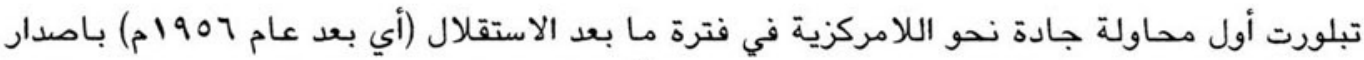

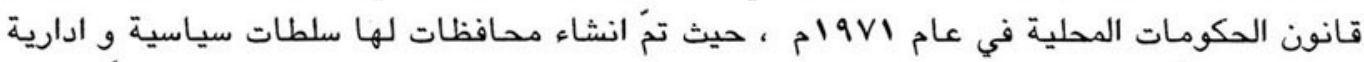

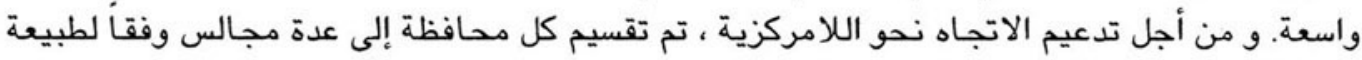

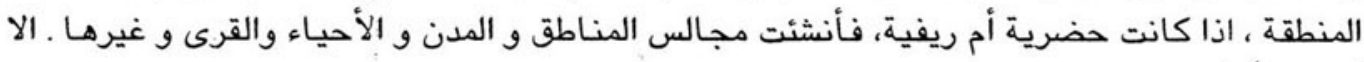

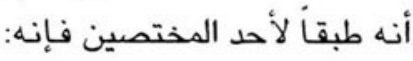

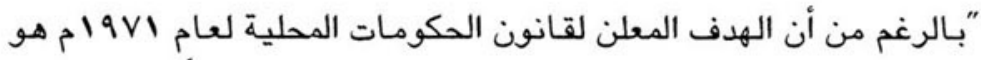

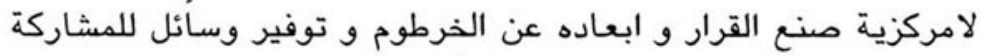

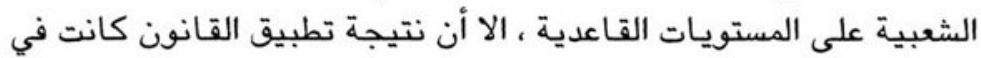

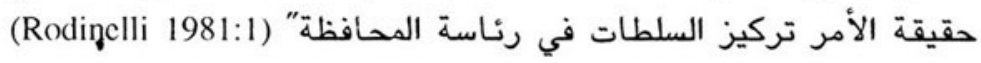

وتمخض اتفاق السلام بين الحكومة و قوات المعارضة الجنوبية في عام

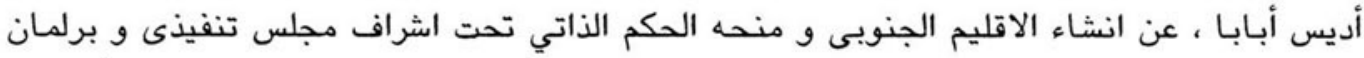

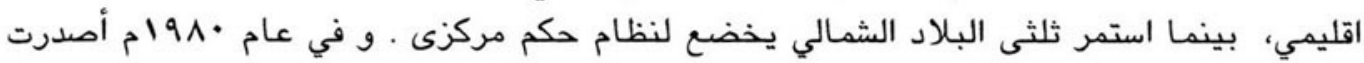


الحكومة قانون الحكم الاقليمي الذي قسمت البلاد بموجبه إلى خمسة أقاليم بـالاضافة إلى كيان مستقل

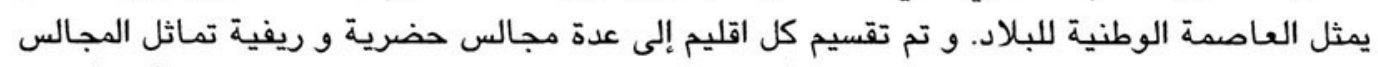

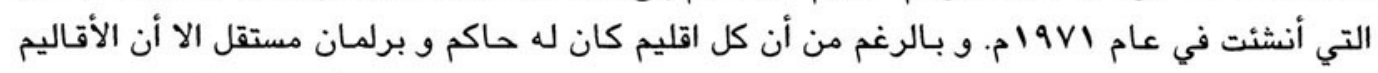

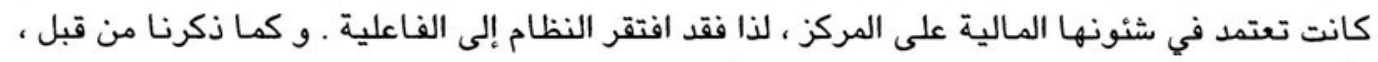

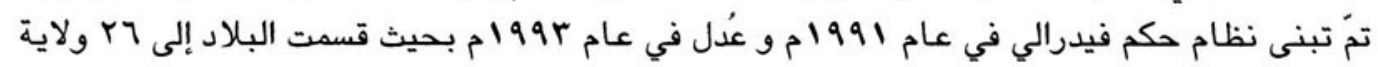

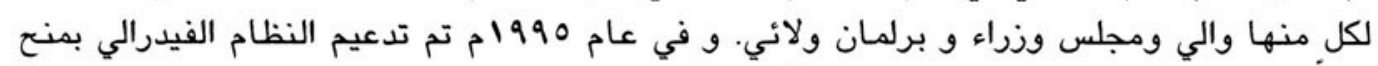

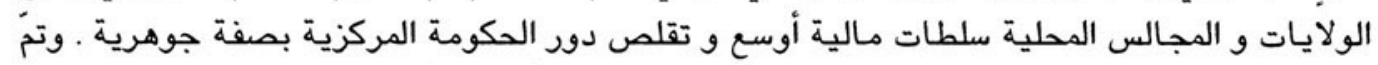

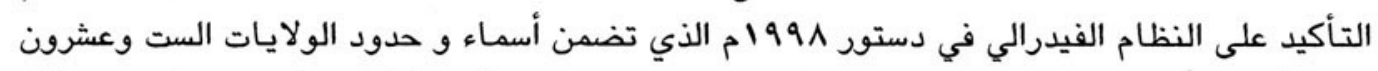

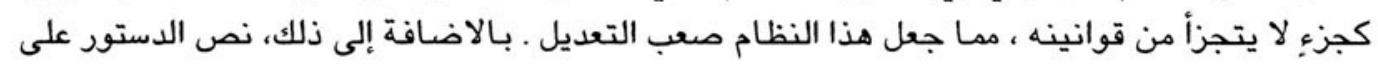
مصادر دخل السلطات المركزية و الولائية و المحلية و قواعد تقسيم الموارد بينها.

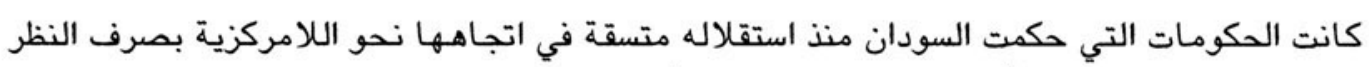

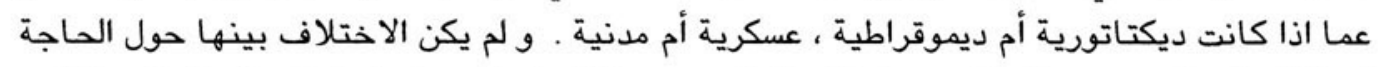

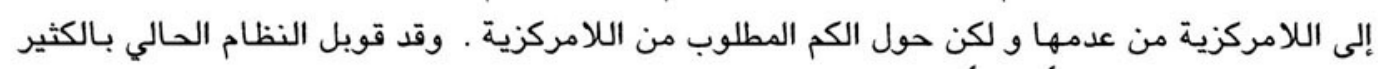

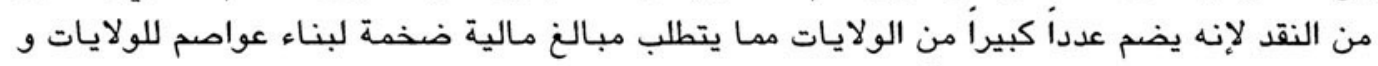

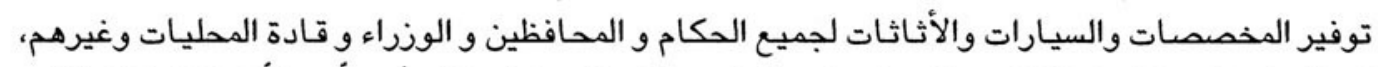

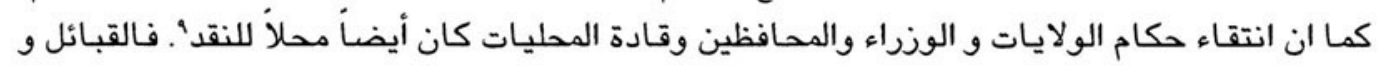

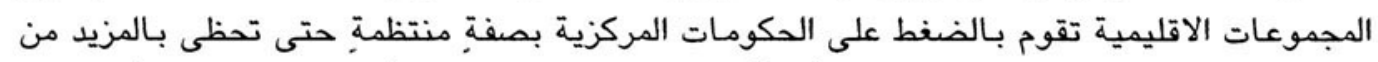

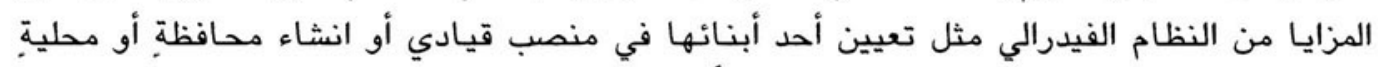

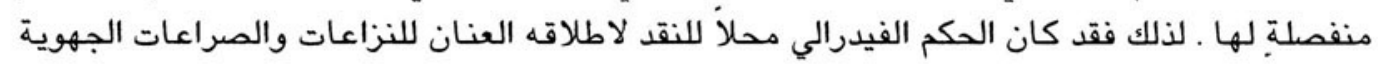

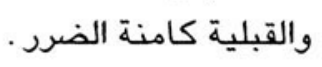

إن الأسس المنطقية التي قدمت لتبرير محاولات اللامركزية التي استعرضناهـا سابقاً هي أن مساحة

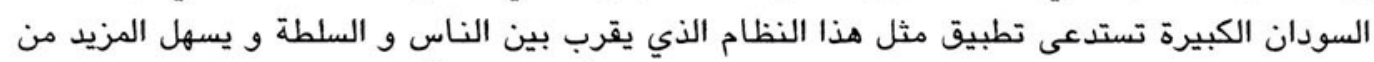

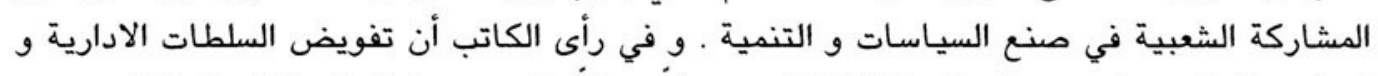

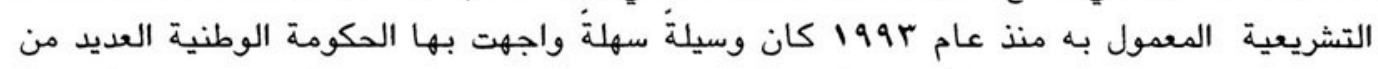

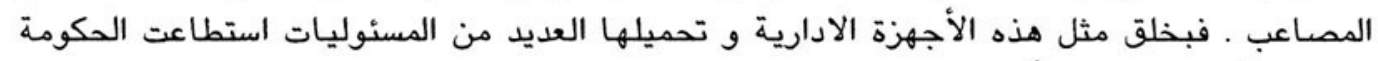

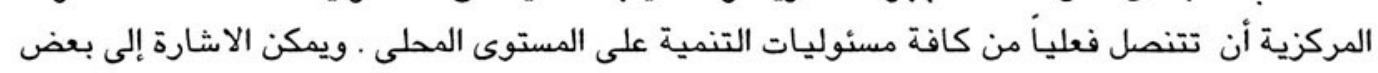

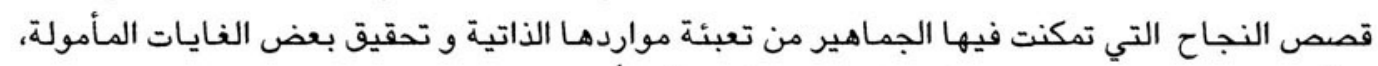
الا أن قصص الاحباط و المحاولات المخيبة للآمال أيضاً عديدة.

نظرياً يسهُّ نظام اللامركزية الذي طبق مؤخرأ سيطرة أعضاء المجتمع أنفسهم على كافة أوجه الحياة 


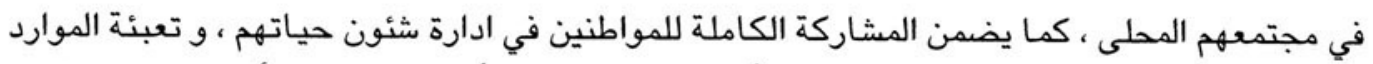

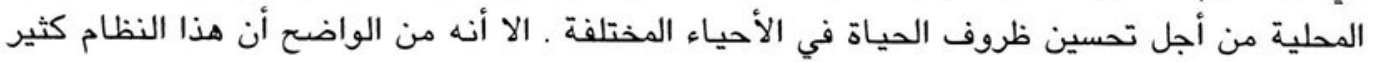

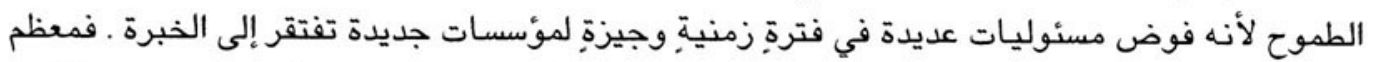

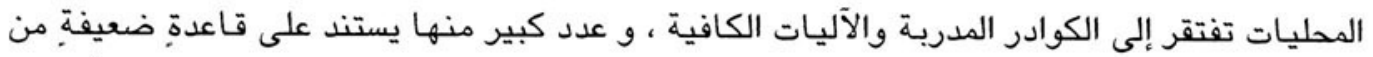

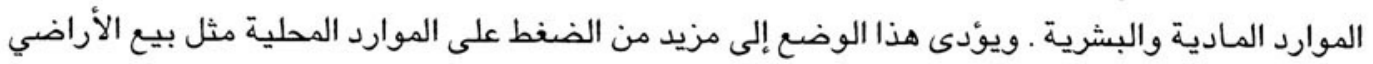

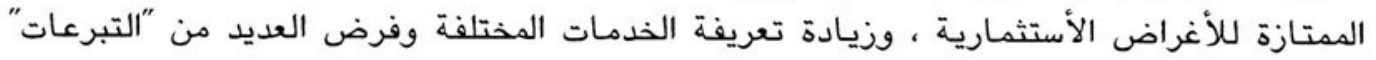

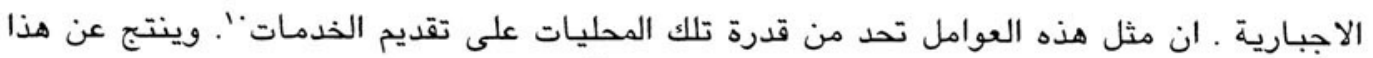

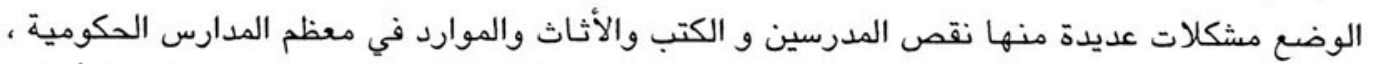

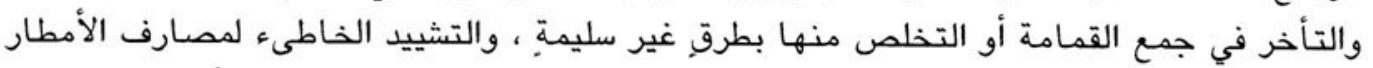
والآثار الصحية الخطيرة الناجمة عن ذلك ، و و برامج ترقية البيئة التي لا يتم تنفيذهـا أبدا.

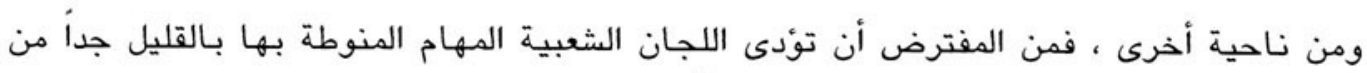

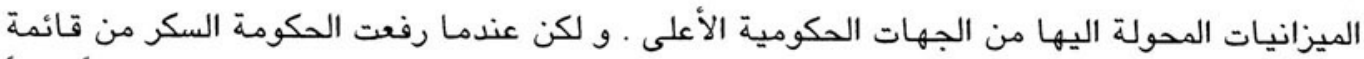

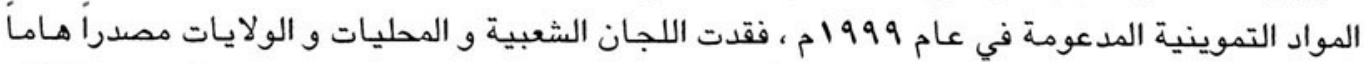

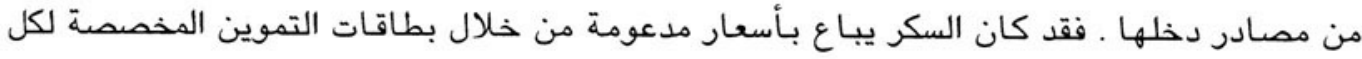

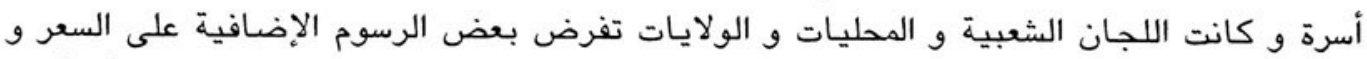

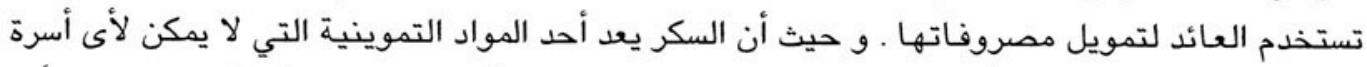

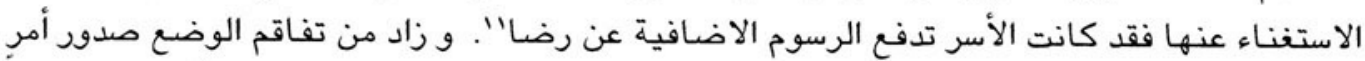

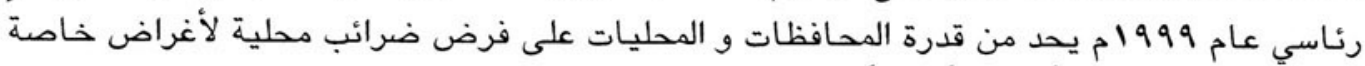

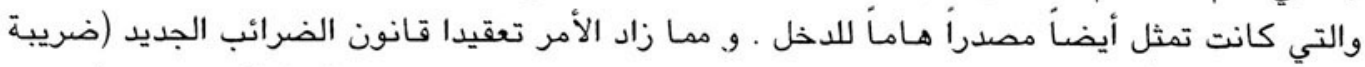

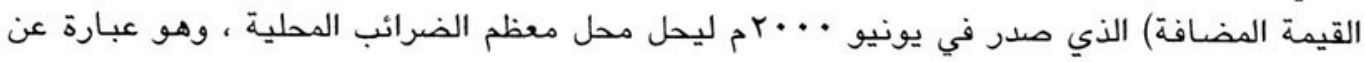

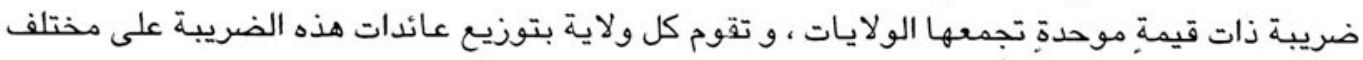

المحافظات والمحليات وفقاً لصيغة معينة

و نتيجة لذلك ألقيت مسئوليات جسيمة على عاتق تلك المؤسسات المحلية في الوقت الذي كانت فيه فعلياً

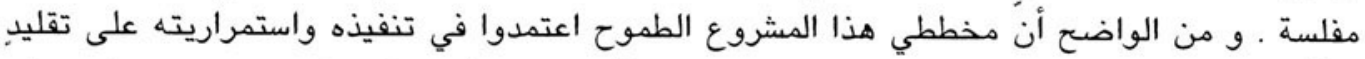

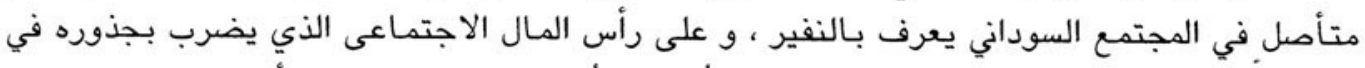

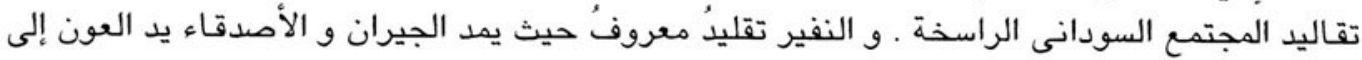

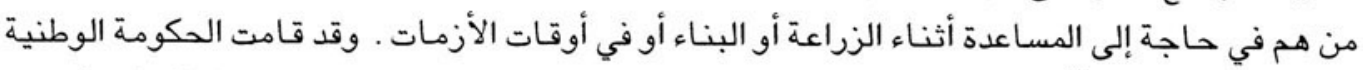

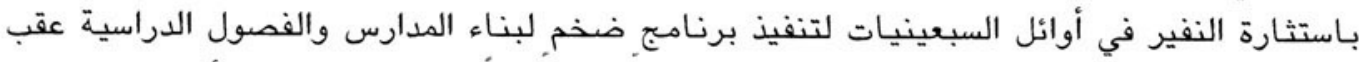

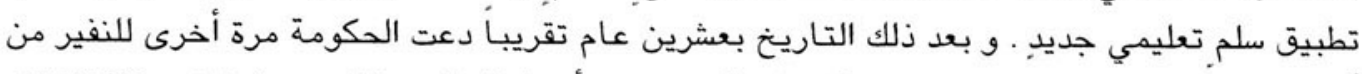

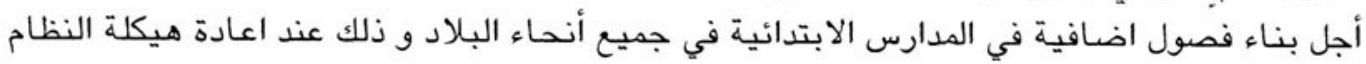




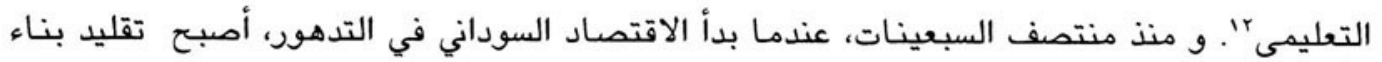

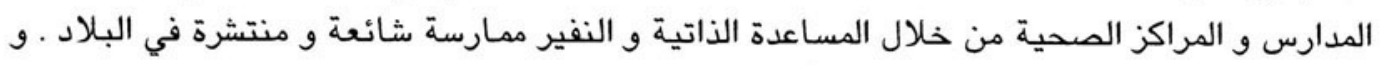

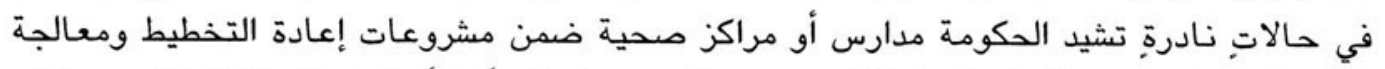

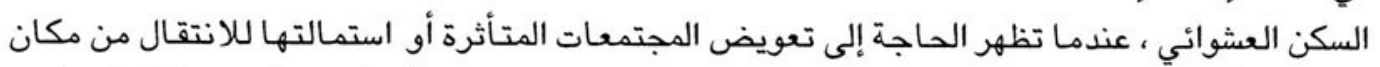

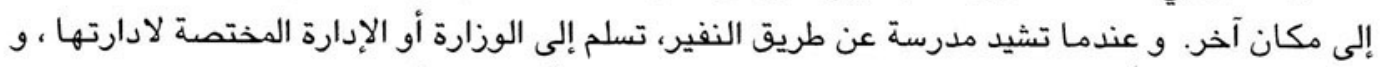

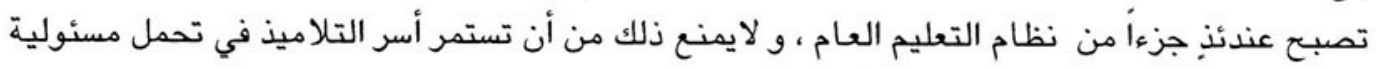
صيانة المدارس و مصروفات تشغئات من نيلها.

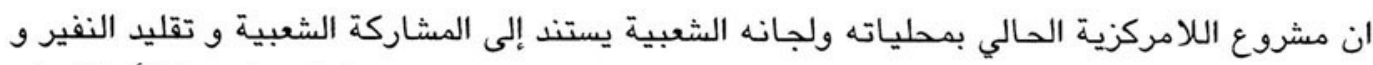

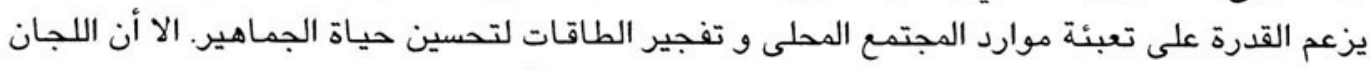

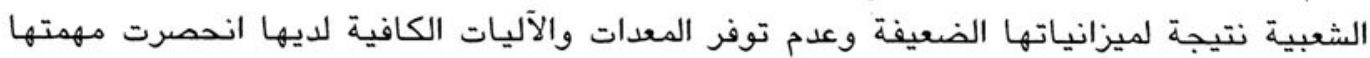

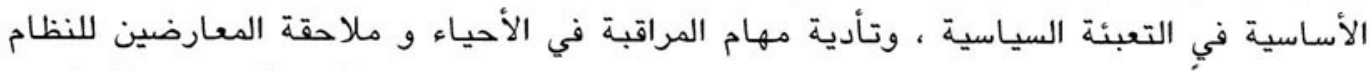

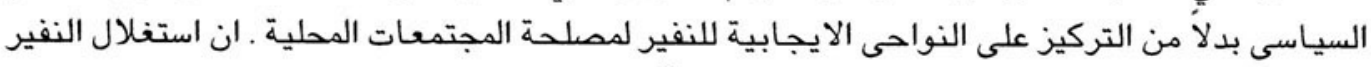

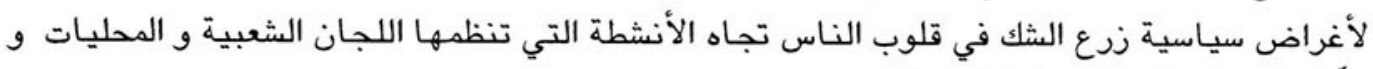

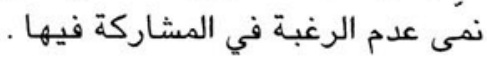

بالاضافة إلى ذلك، فان هذا النظام اللامركزى المحكم قد تم فرضه فوق مؤسسات اجتماعية قديمة مثل

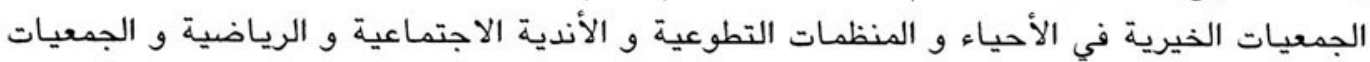

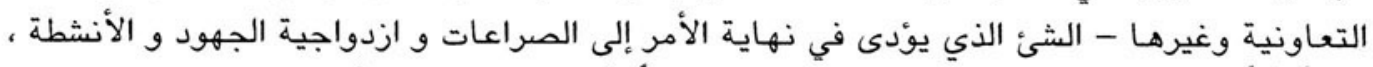

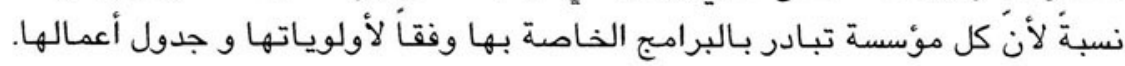

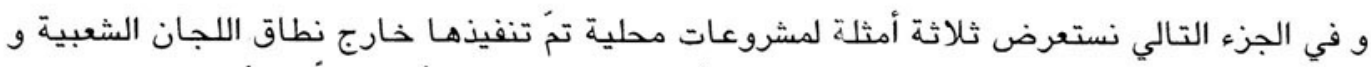

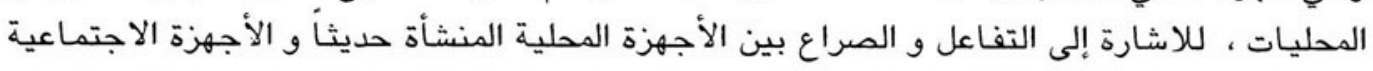

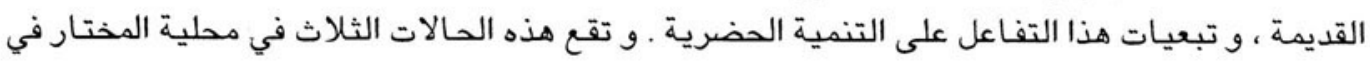
محافظة الخرطوم بحري.

\section{رابـعاً: نماذج مختارة لأسلوب الحكم الحضري في الخرطوم الكبرى}

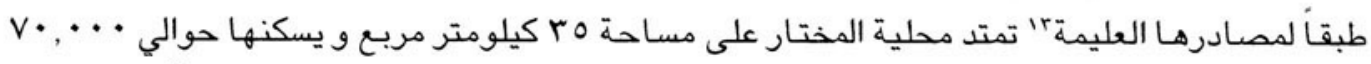

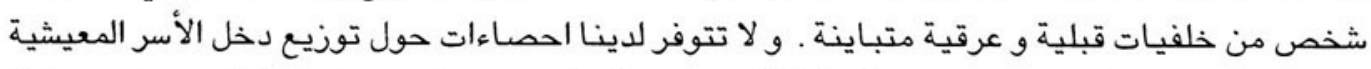

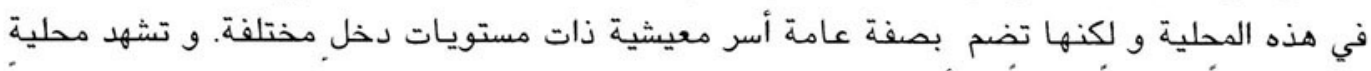
المختار نموأ حضرياً سريعاً في أجزائها الشمالية و الشرقية حيث يتم تشييد مناطق سكنية حديثة نسبياً 


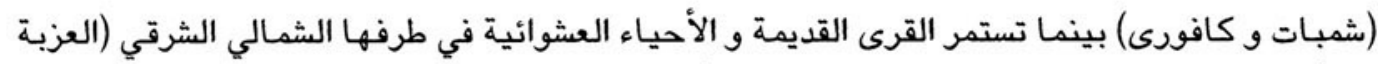

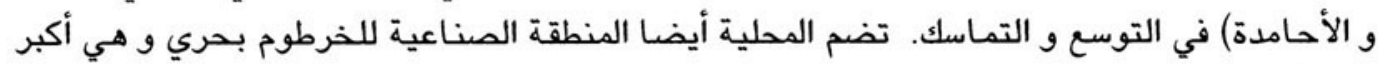

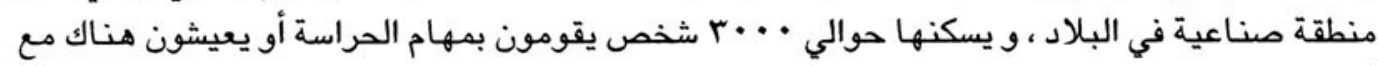

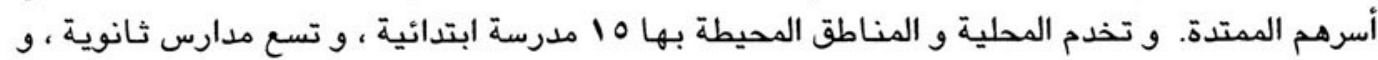

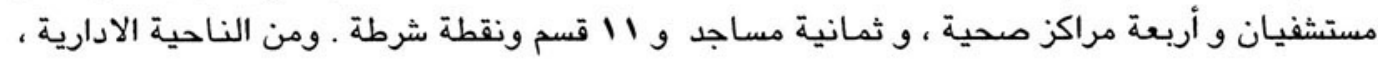

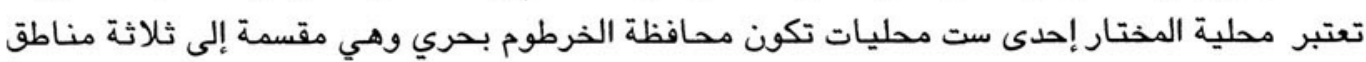

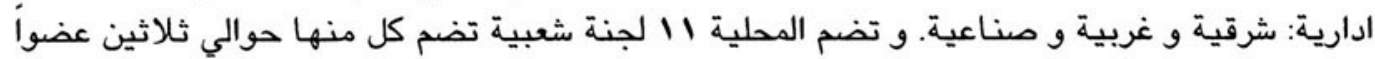

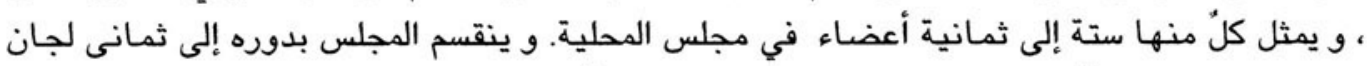

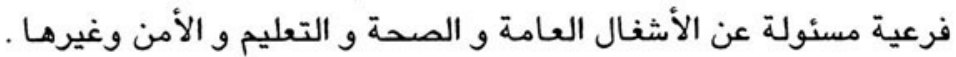

\section{الحالة الأولى: تقديم الخدمات في مرئع 9 مدينة كافـوري}

كانت كافوري مزرعة كبيرةً تبعد حوالي خمسة كيلومترات من مركز محافظة الخرطوم بحري ، تملكها

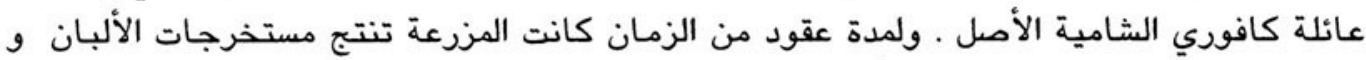

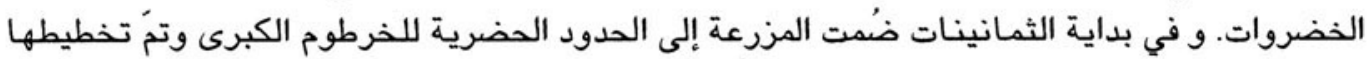

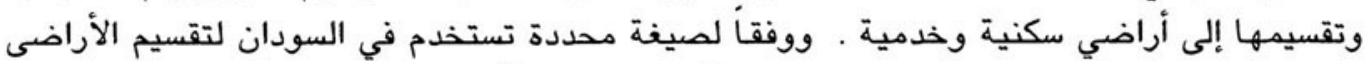

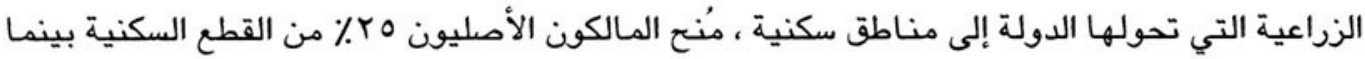

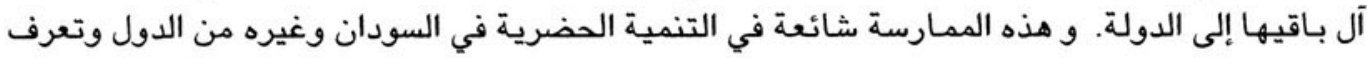

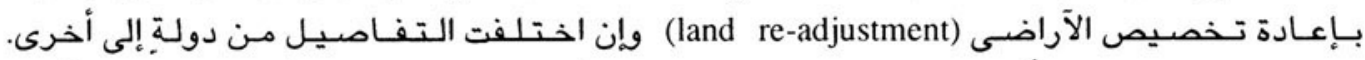
(Doebele, 1982)

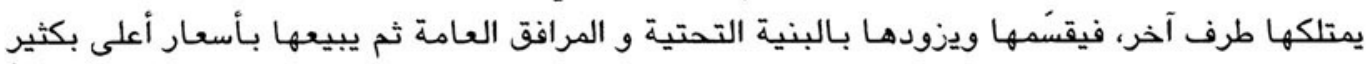

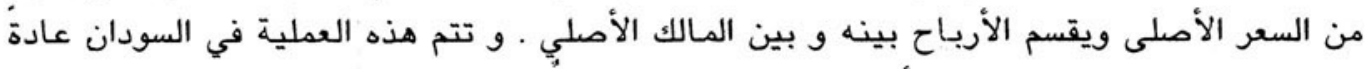

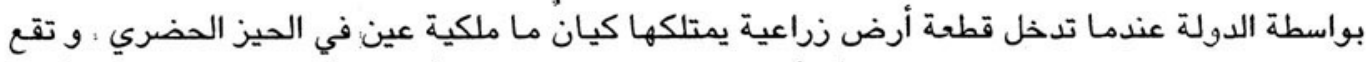

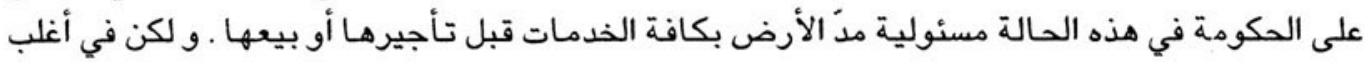

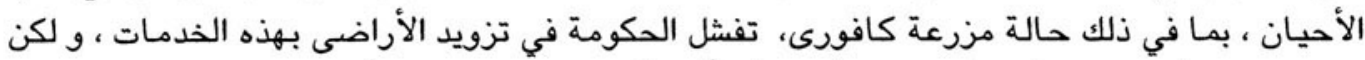

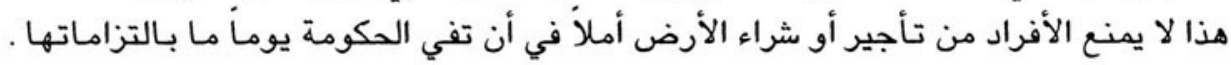

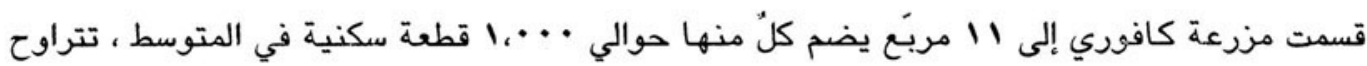

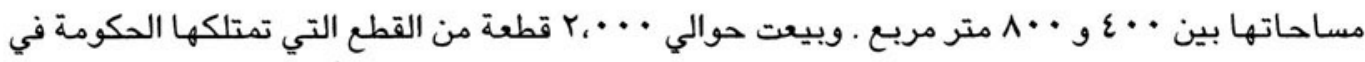

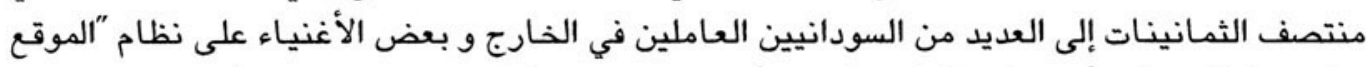

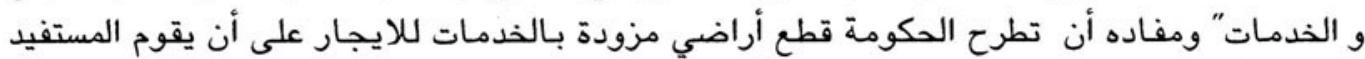

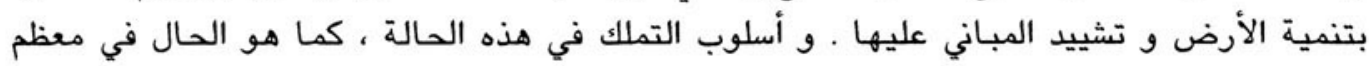




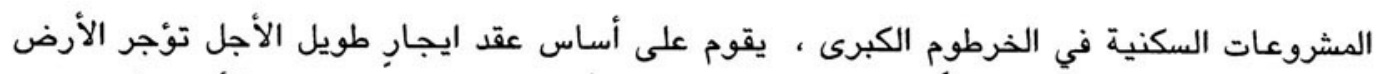

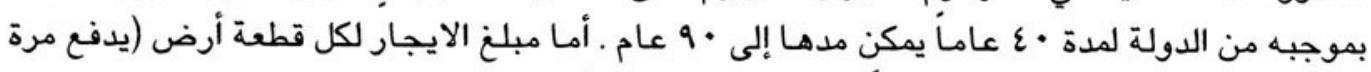

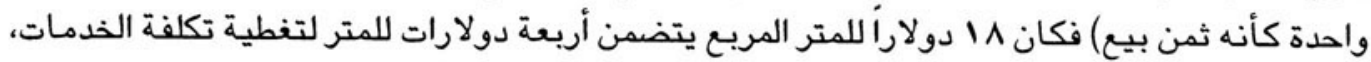

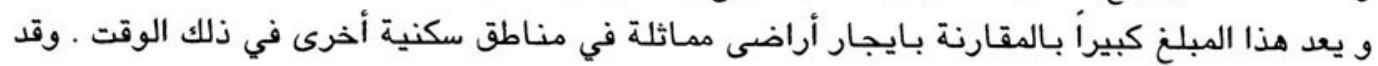

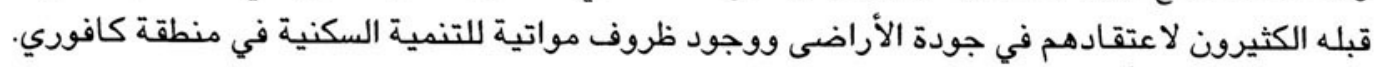

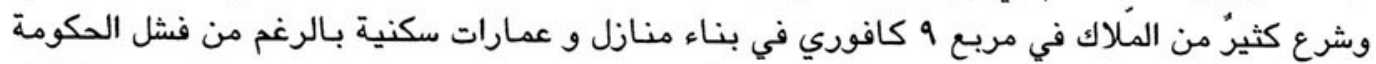

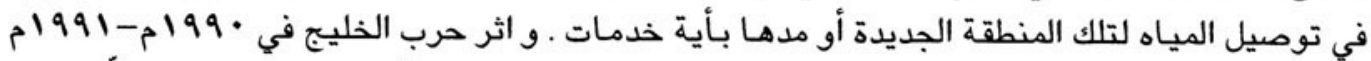

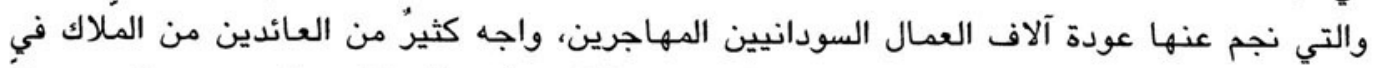

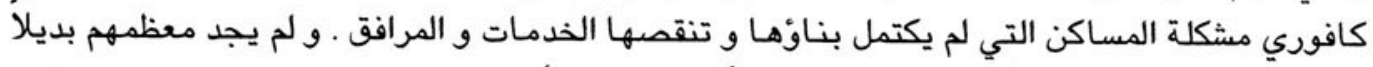

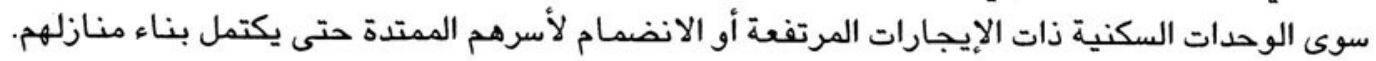

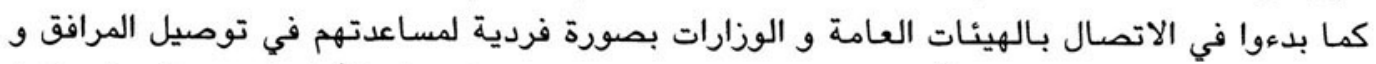

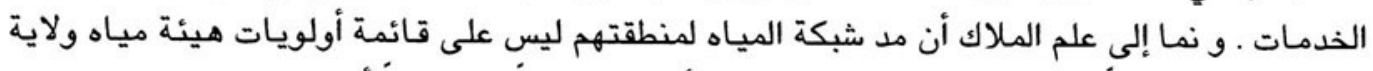

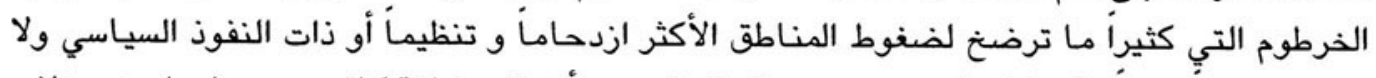

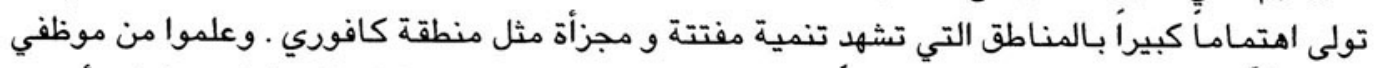

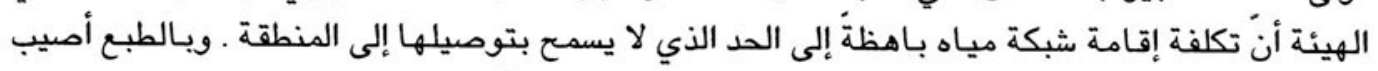

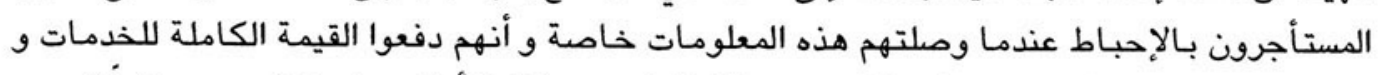

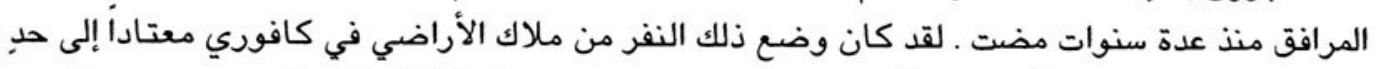

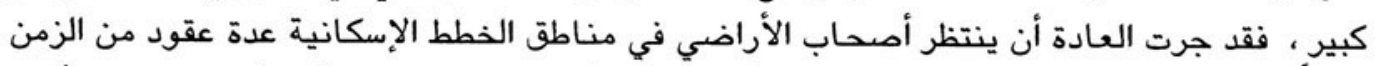

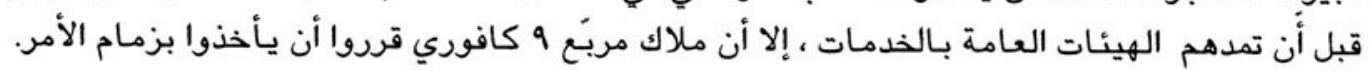

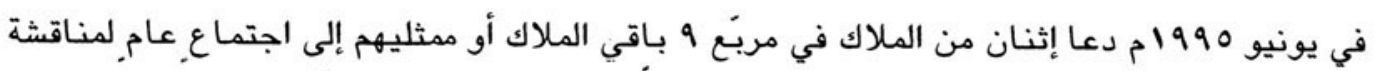

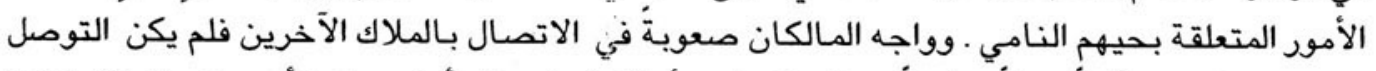

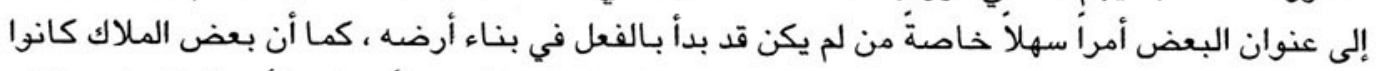

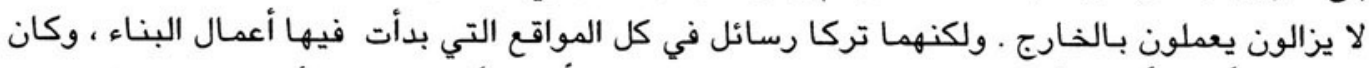

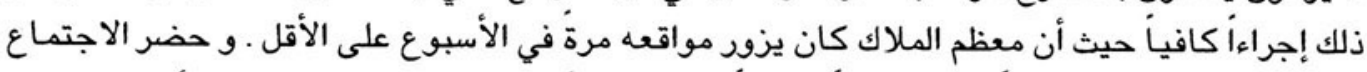

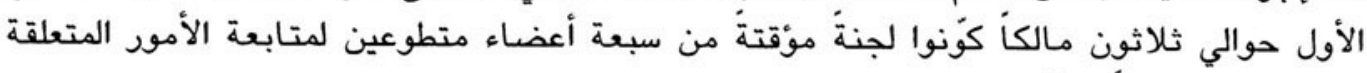
بالخدمات ، خاصةً مسألة توصيل المياه.

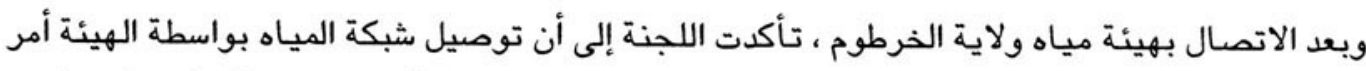

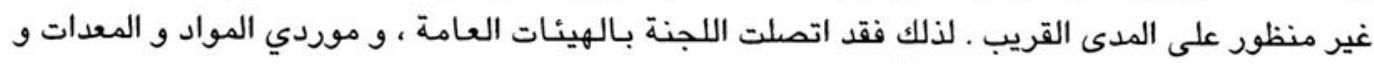

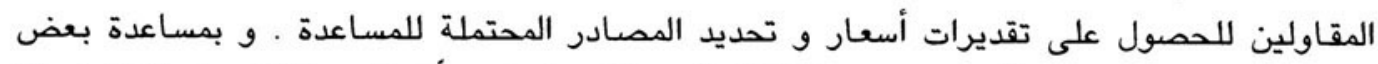

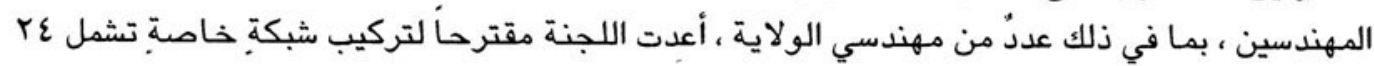




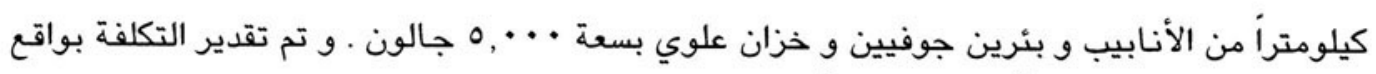

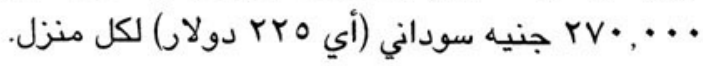

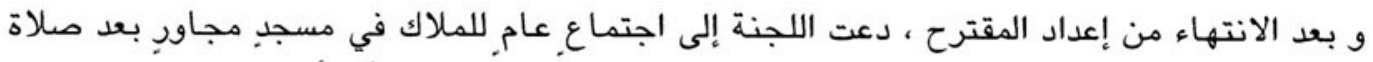

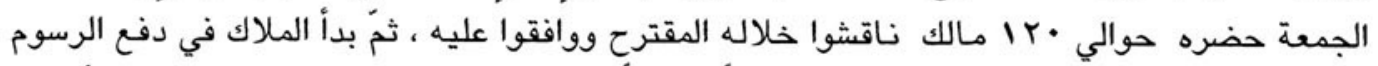

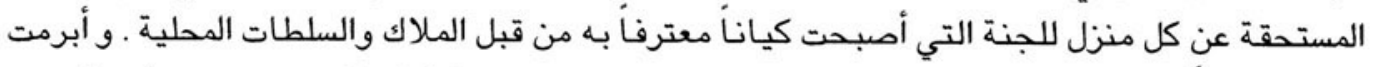

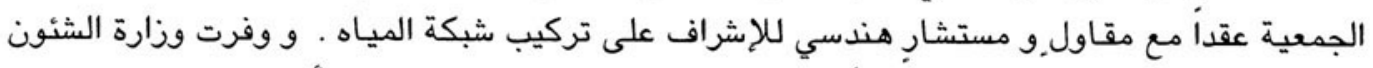

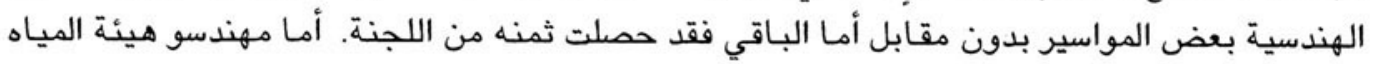

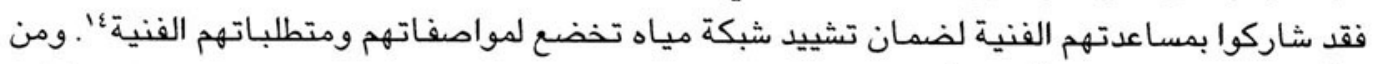

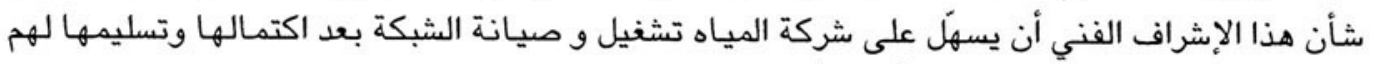

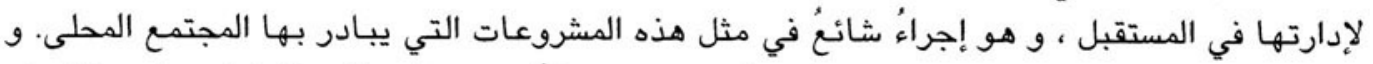

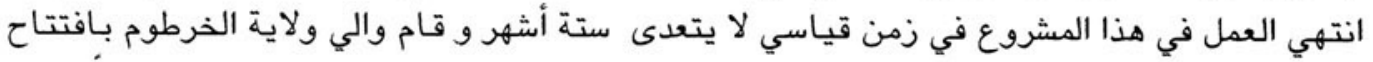

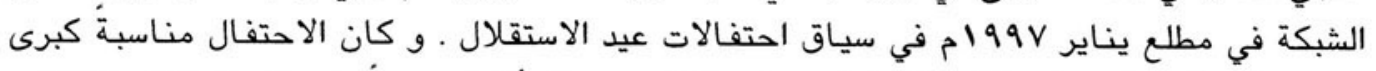

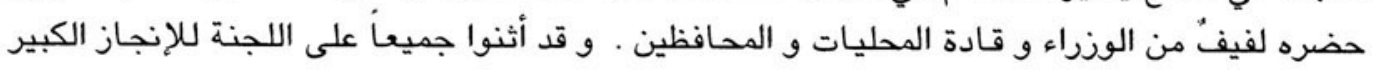

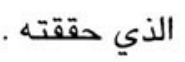

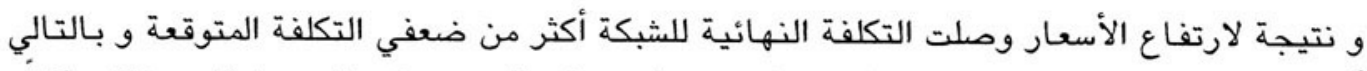

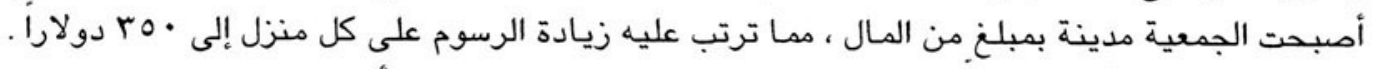

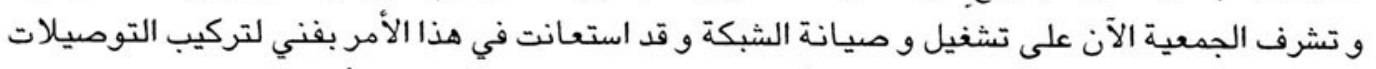

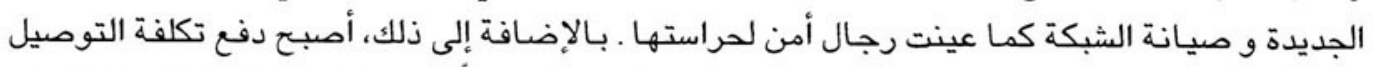

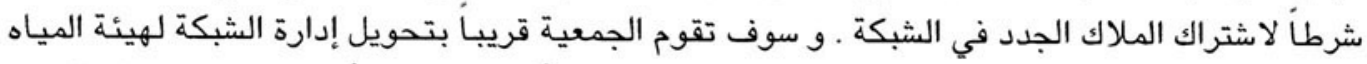

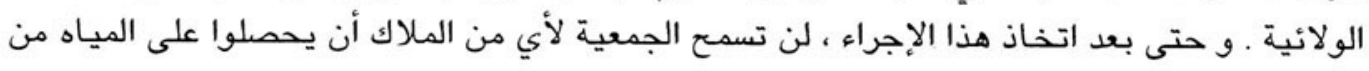

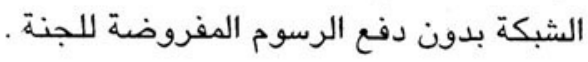

ومنذ أن أكملت اللجنة شبكة المياه ، ارتفع ثمن الأراضي في مربنع 9 كما شرع العديد من الملاك في بناء

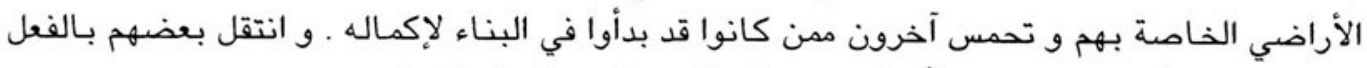

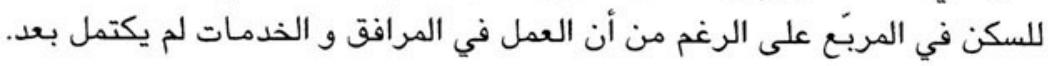

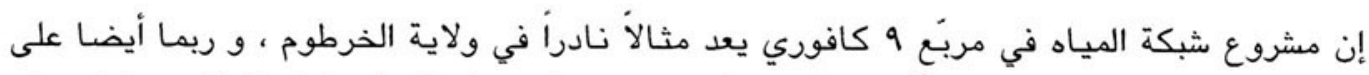

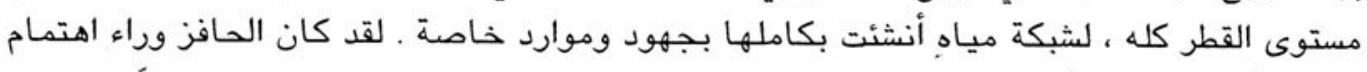

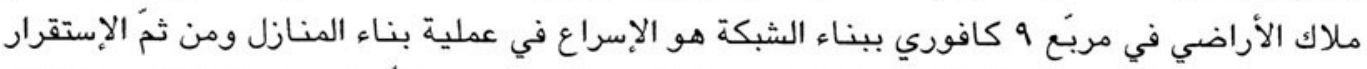

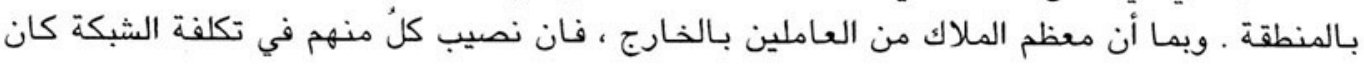




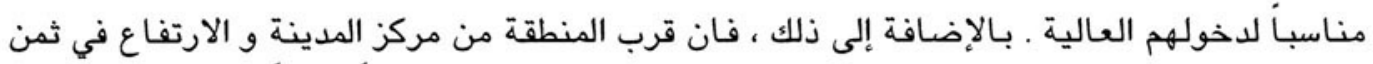

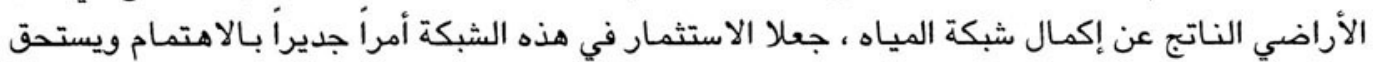

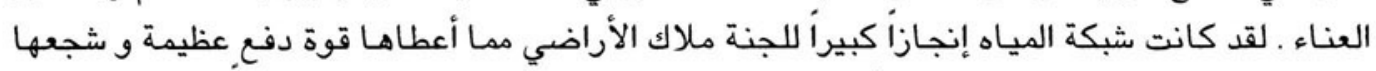

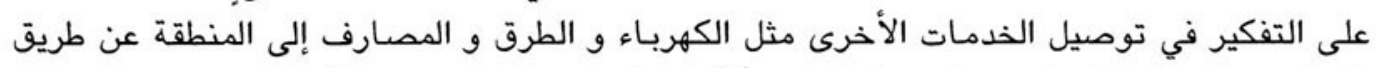

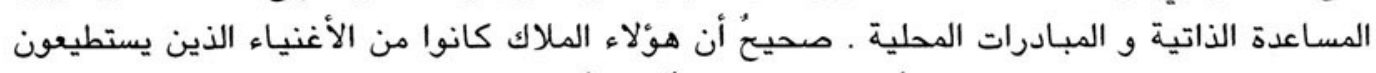

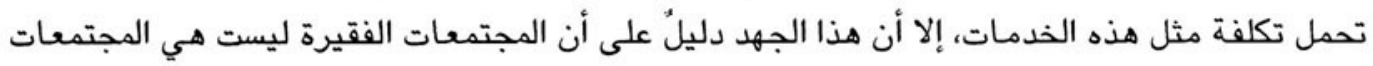

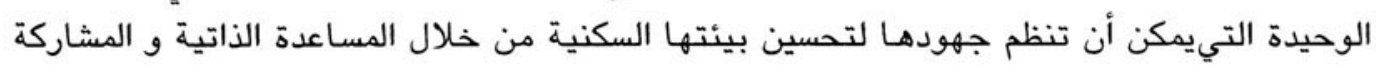
الشعبية .

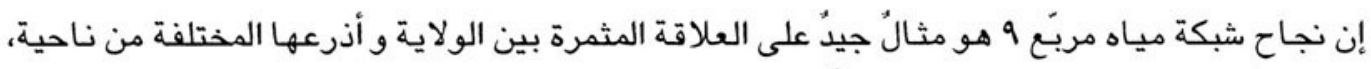

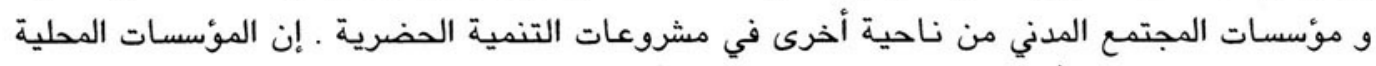

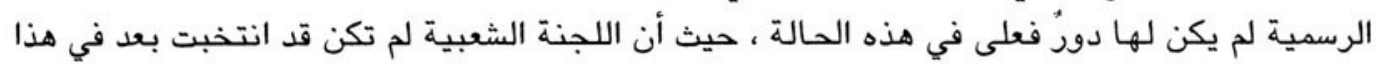

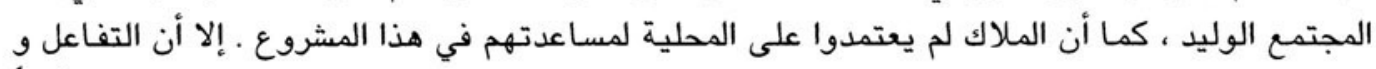

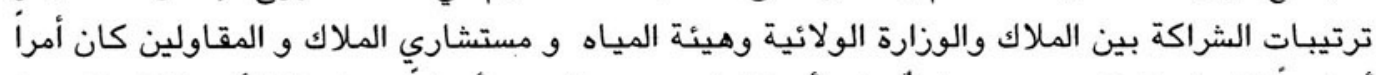

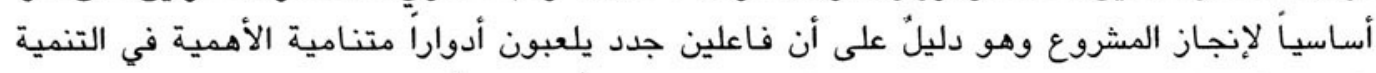
الحضرية تخالف النموذج التقليدي للتنمية الذي ينبثق من أعلى إلى أسفل (top-down).

الحالة الثانية: مشروع الشارع النموذجي في المزاد شمال ، الخرطوم بحري تقع هذه الحالة في منطقة المزاد شمال التي أنشئت في بداية الستينات عندما خصصت أراضى سكنية

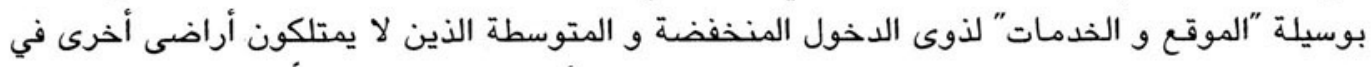

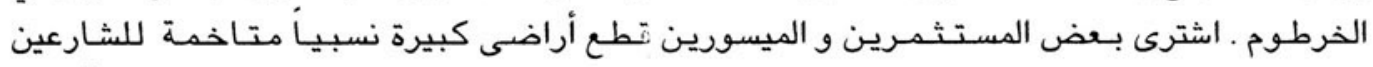

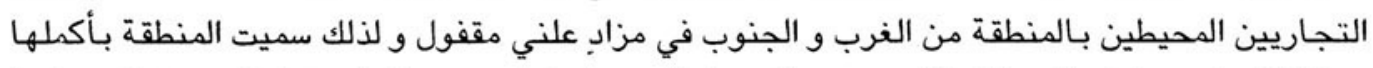

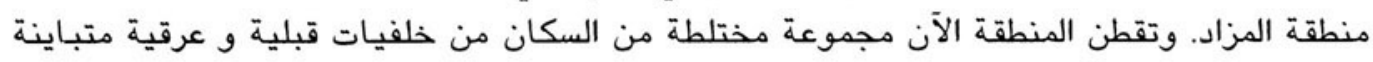
معظمهم من شمال وأواسط السودان.

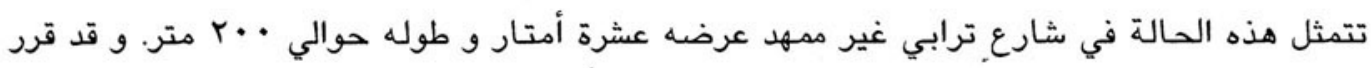

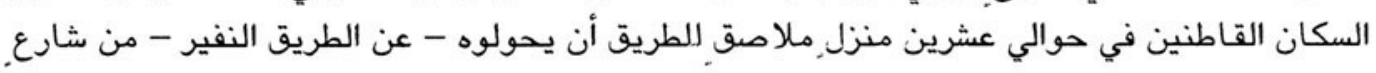

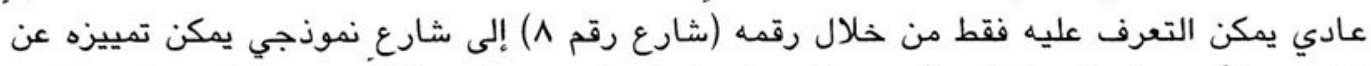

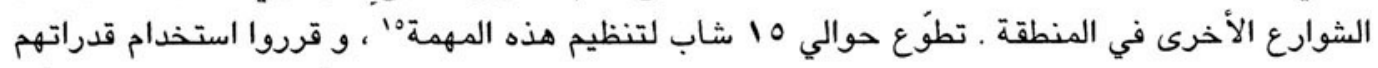

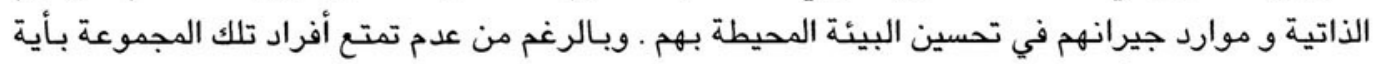

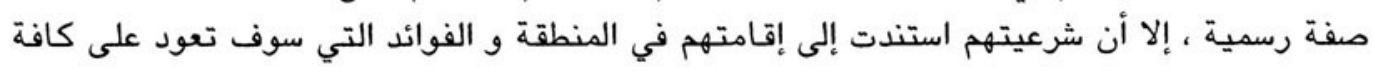


سكان الحي من هذا المشروع ـ لم يكن في استطاعة السكان بناء طريق أسفلت دائم و ممهد لذا فقد اكتفوا

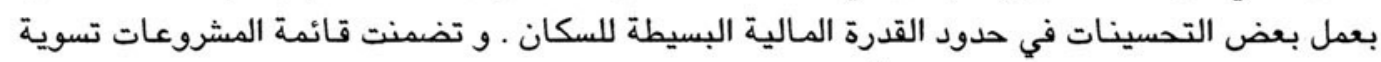
و تنظيف الشارع ، و إضـاءته وزرع الأشجار على جانبيه.

ومن أجل تمهيد الشارع و تسويته ، أقنعت المجموعة السلطات المحلية بـأن تعيرهـا آلة تمهيد الترية (الخاصة بها ، وفي مقابل ذلك تولى الأفراد دفع ثمن الوقود و قدموا حوافز مالية للعاملين

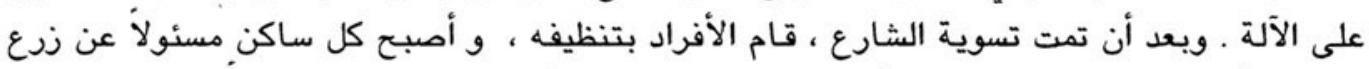

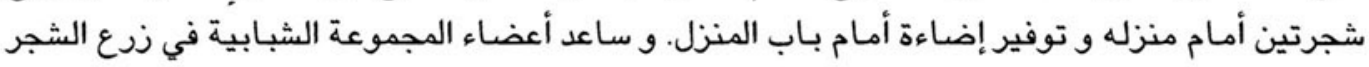

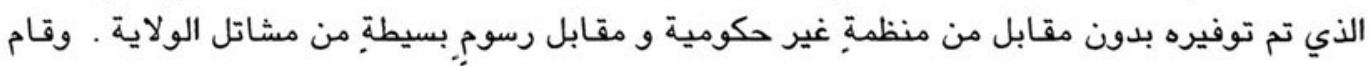

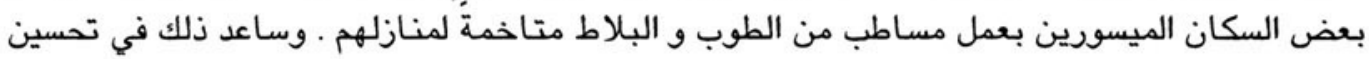
هيئة الشارع و صقله و إضفاء صفة المتانة عليه.

شعر قاطنو الشارع بـالفخر نتيجة انجـازهم فمنحوا شارعهم لقب "الشارع النموذجي" ووضعوا علامة

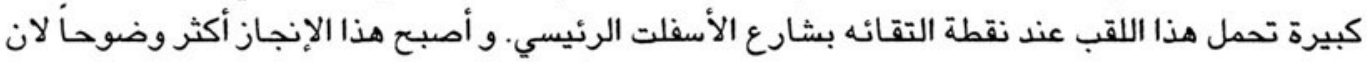

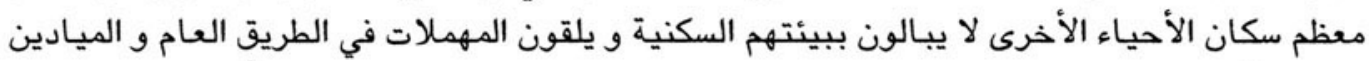

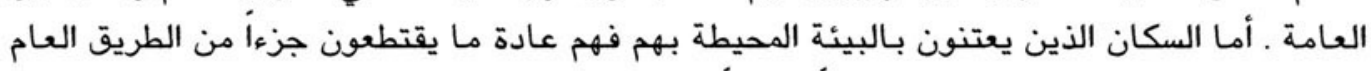
فيزرعونه و يستخدمونه كما لو كان ملكاً خاصناً بهم.

أعطى نجاح المرحلة الأولى من المشروع دفعة معنويةً لساكني الشارع و شجعهم على تعبئة جهودهم الذاتية للمشاركة في هذا الجهد و الشروع في المرحلة الثانية التي تضمنت إنشاء جسر صغير فوق المصرف الذي يقاطع الشارع عند نقطة التقائه بالطريق الرئيسي . و جاءت قوة الدفع الرئيسية لهذا

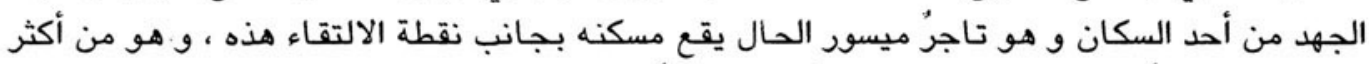

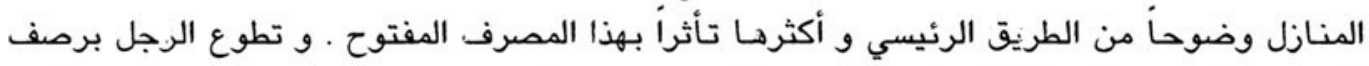

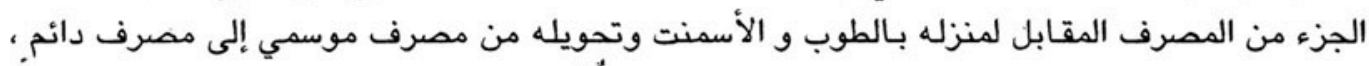

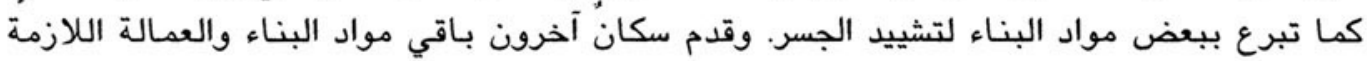

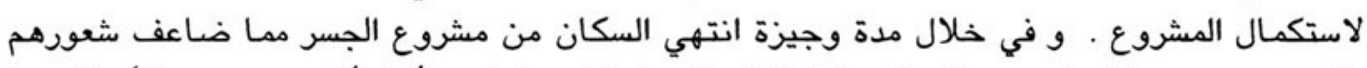

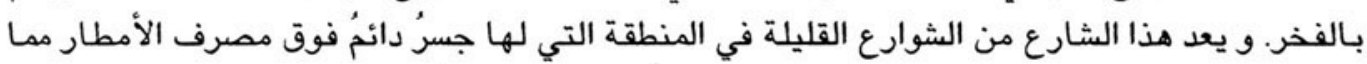

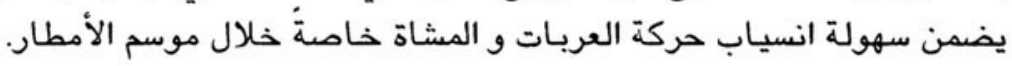

و يـأمل السكان أن يتمكنوا من تنفيذ مشروعات أخرى مثل بناء مصرف فرعي دائم لتصريف المياه

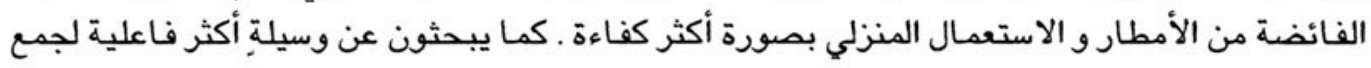
القمامة و التخلص منها ـ و المشكلات التي تواجه السكان في هذا الصدد مشتركة و شائعة يعانى منها 
أغلب قاطني المدينة ، وهي ناجمةُ عن المشكلات الاقتصادية التي تضطر الناس للعمل سُاعاتِ طويلة.

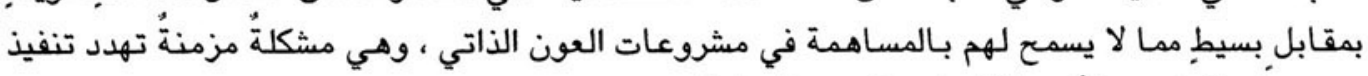

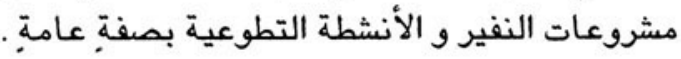

إن حالة الشارع النموذجي هي قصة نجاح أخرى تحدث خارج نطاق المؤسسات الرسمية و بمساعدةٍ

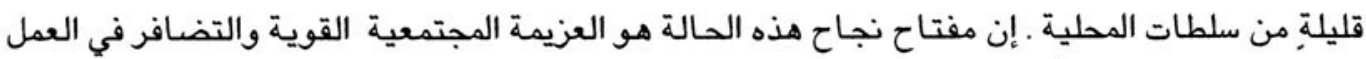

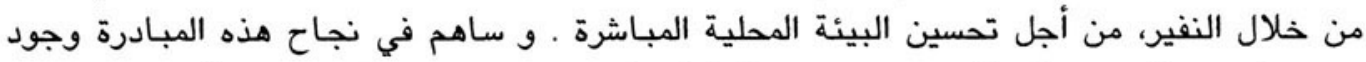

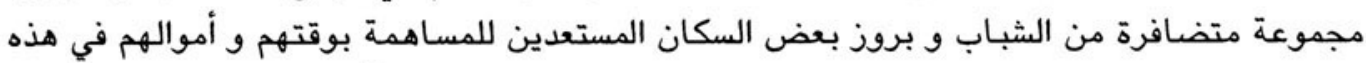

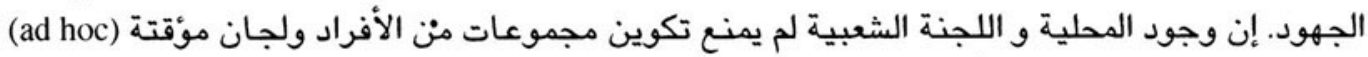

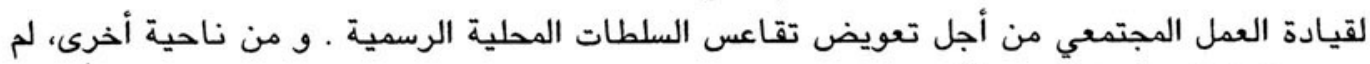

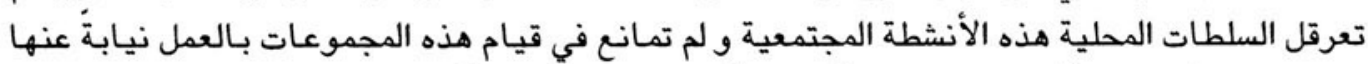

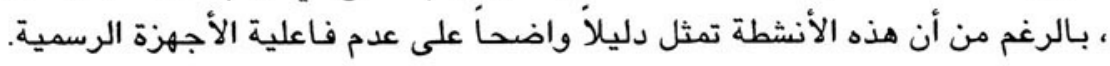

الحالة الثالثة: تشييد مركز اجتماعي في منطقة المزاد شمال ، الخرطوم بحرى

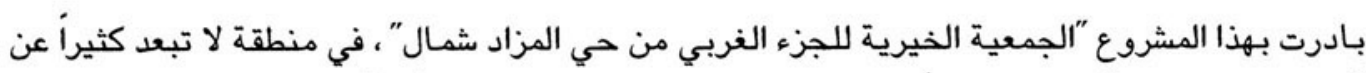

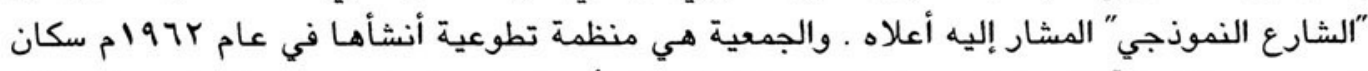

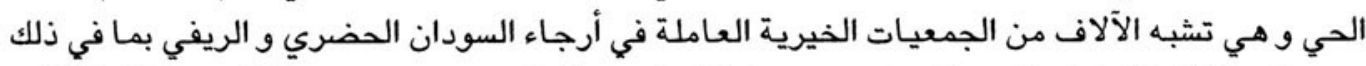

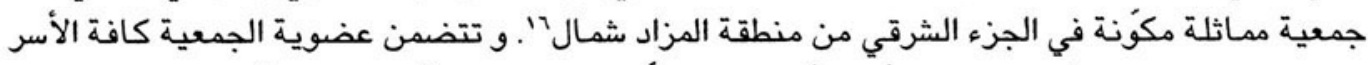

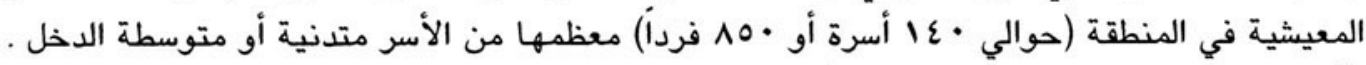

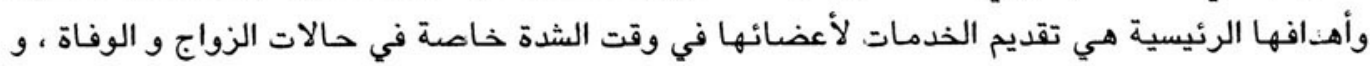

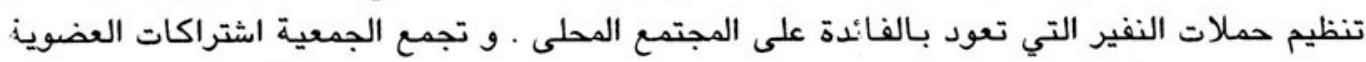

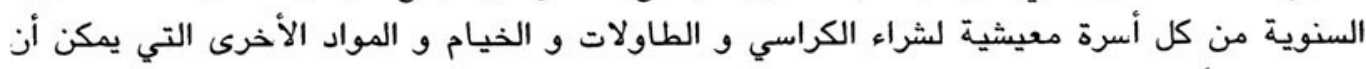
يقترضها الأعضاء عند الحاجة.

و في منتصف السبعينيات أقنعت الجمعية الحكومة المركزية أن تسجل ملكية الميدان الذي يتوسط الذبا

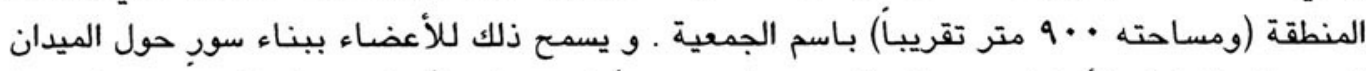

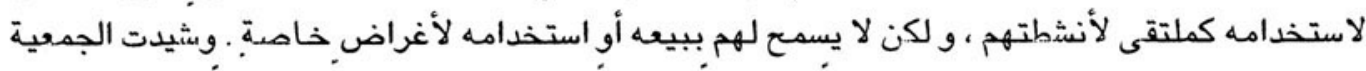

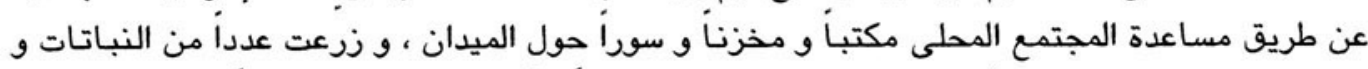

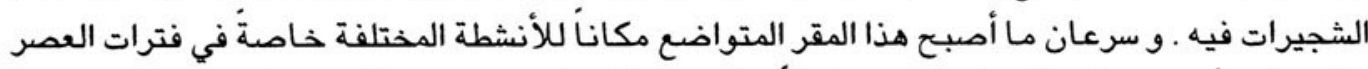

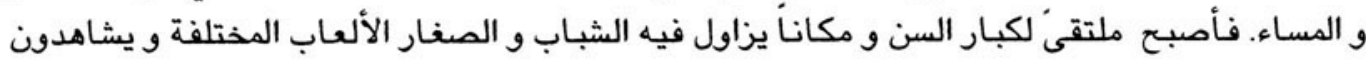

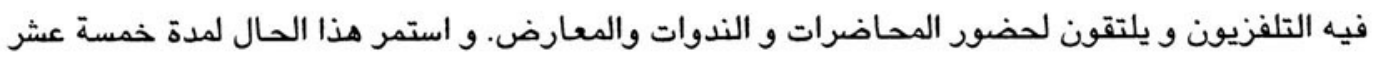


عاماً حتى اقترح أحد أقارب عضو من الأعضاء توسيع المركز و النهوض به بـاستخدام الأموال المقدمة

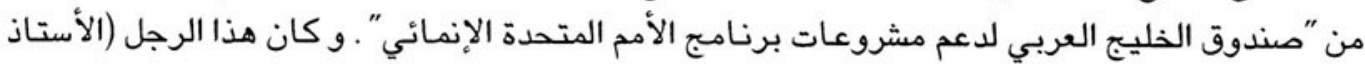

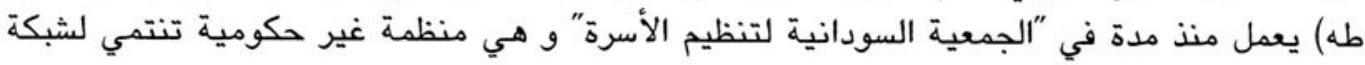

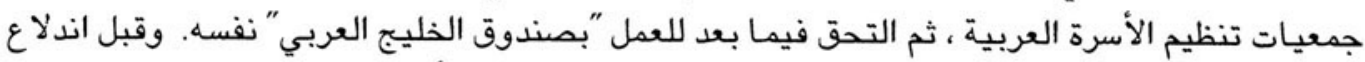

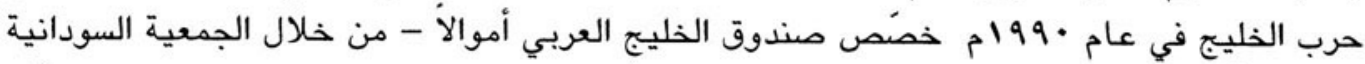

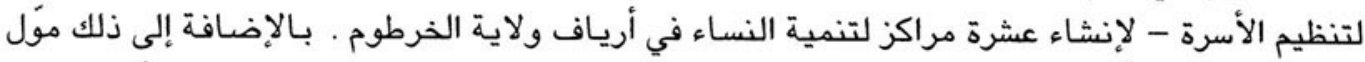

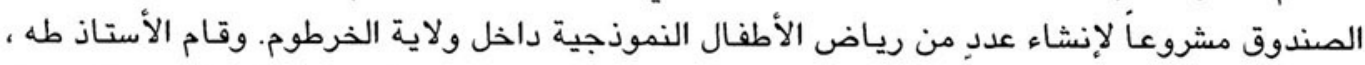

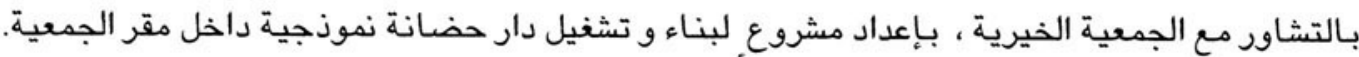
و قسمت أنشطة المشروع إلى ثلاثة مراحل:

(1) بناء مبنى للحضانة محاطاً بشرفة واسعة و و مساحات خضات خضراء للعب الأطفال و الأنشطة الاجتماعية الأخرى.

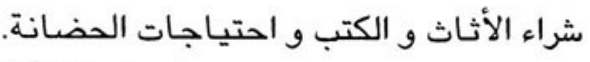
(r) توفير المواصلات و الوجبات المجانية للأطفال و توفير مصروفات التات التشغيل.

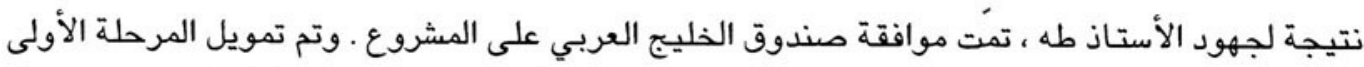

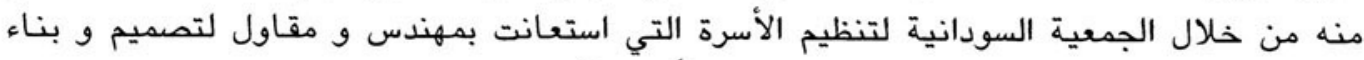

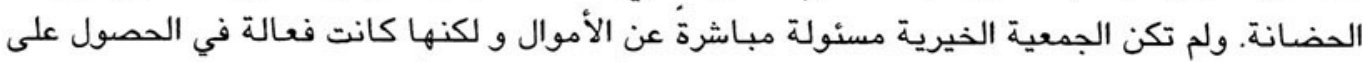

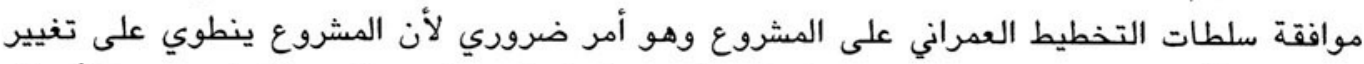

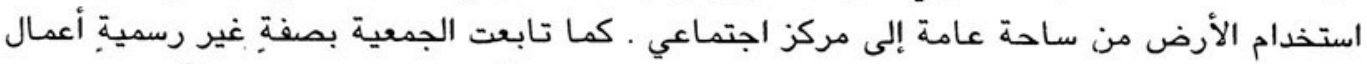

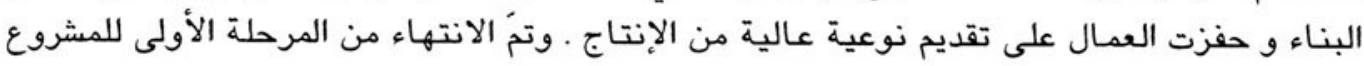
بمقاييس بناء جيدة تفوق أي بناء متوسط في منطقة المزاد شمال .

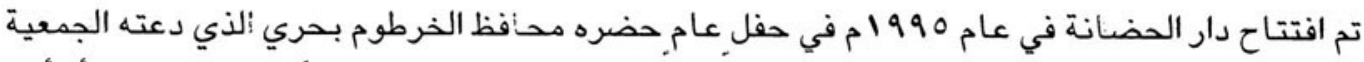

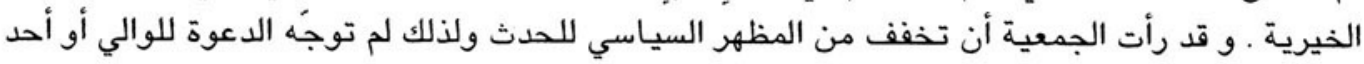

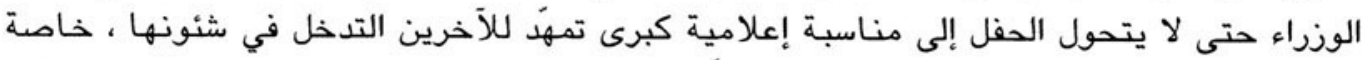

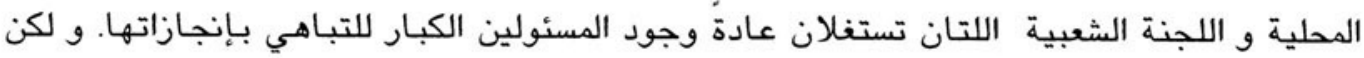
للأسف ، تحققت مخاوفهم أسرع مما توقعوا فسرعان ما ظهرت الصراعات حول السات السيطرة على المركز

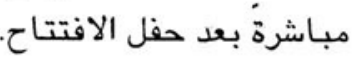

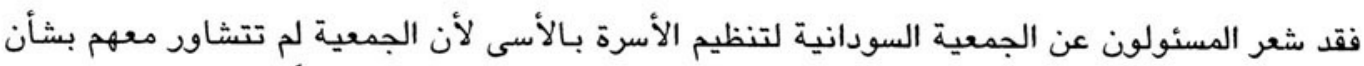

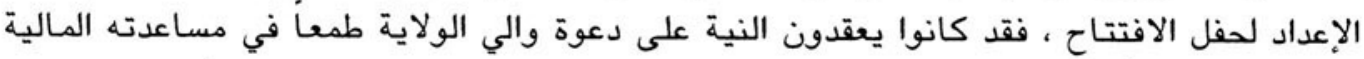

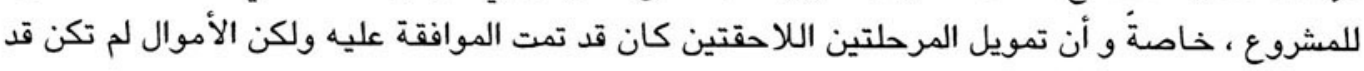


صرفت بعد وفقا للجدول المتفق عليه، نتيجة لبعض التعقيدات السياسية التي نجمت عن حرب الخليج.

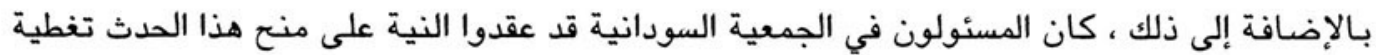

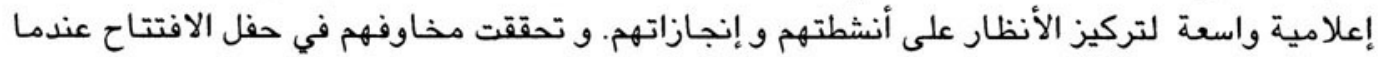

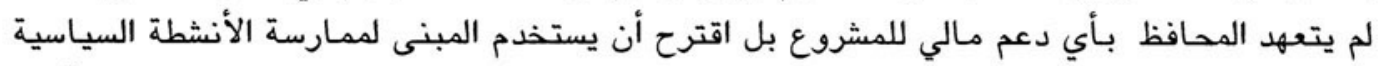

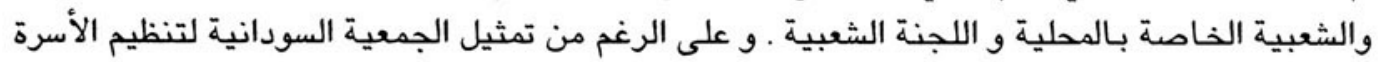

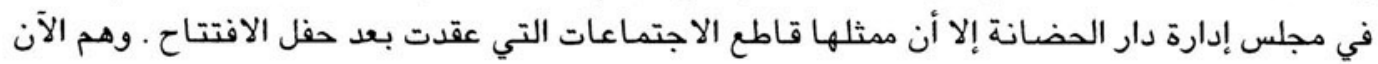
بانتظار حل للخلاف الناشئ بين الجمعية و اللجنة الشعبية حول التحكم التحم والسيطرة على المركز.

أمـا أعضاء اللجنة الشعبية الذين لم يكن لهم أي دور في المشروع ، فقد شعروا أنه ينبغي لهم السيطرة

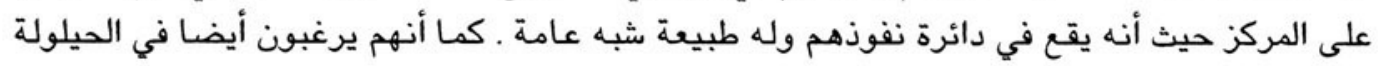

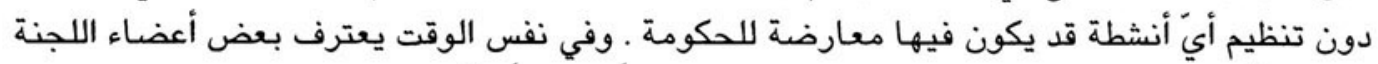

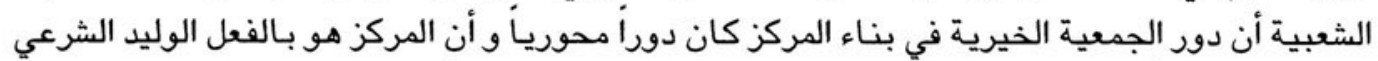

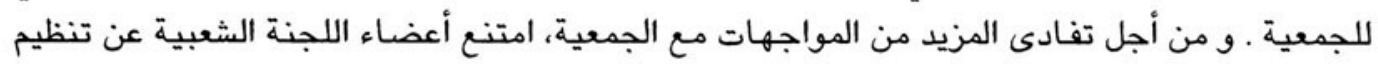

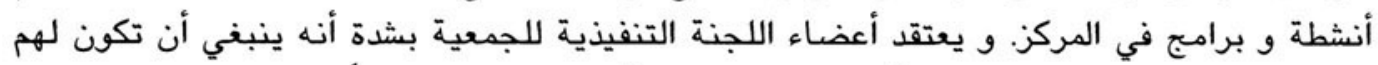

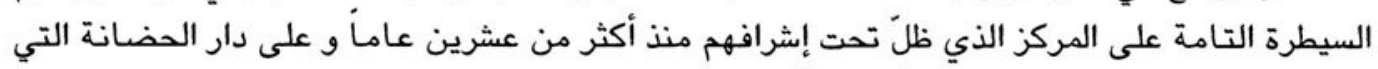

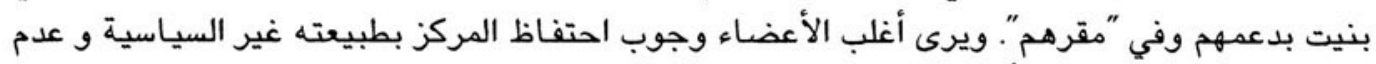
إعطاء الجنة الشعبية فرصة للتدخل في أنشطته.

حدثت بعض المواجهات بين أعضاء اللجنة الشعبية و أعضاء الجمعية واتهج كلٌ منهما الآخر بمحاولة

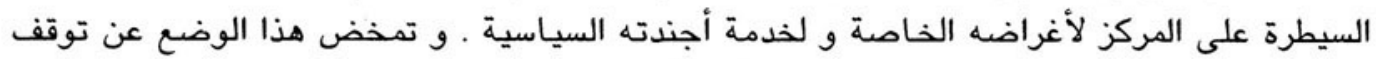

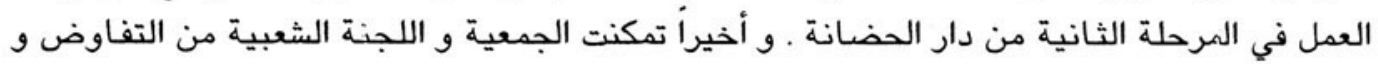

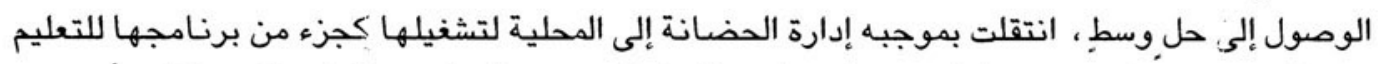

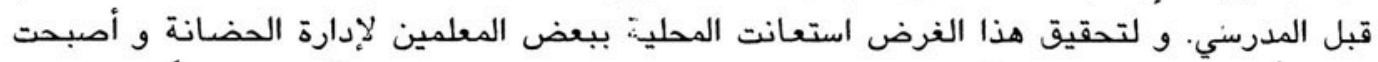

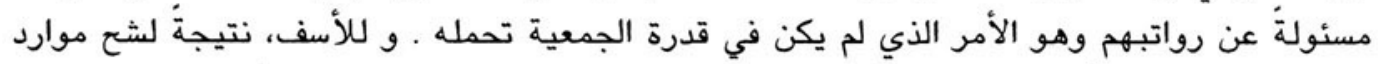

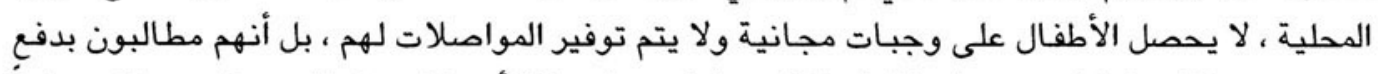

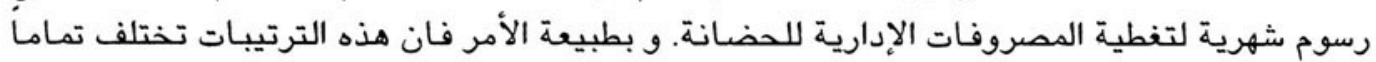

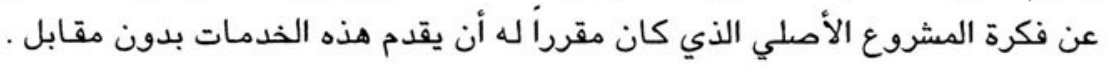

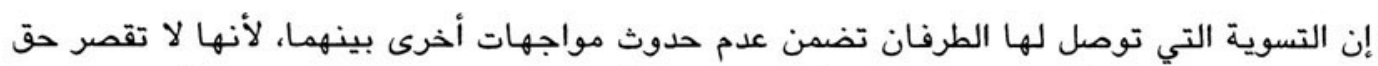

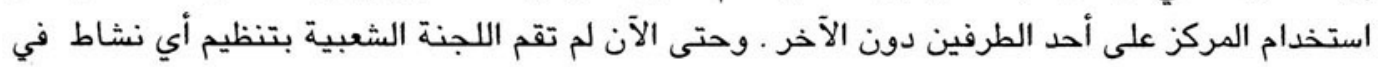

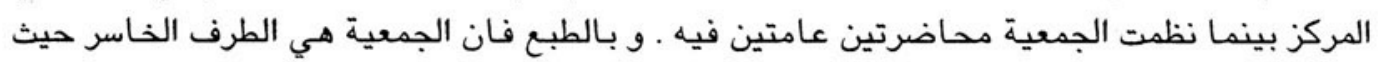

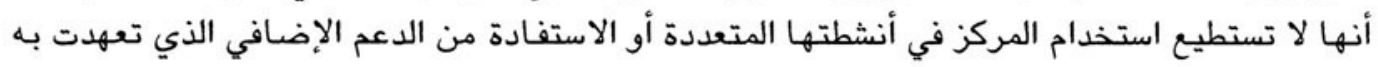




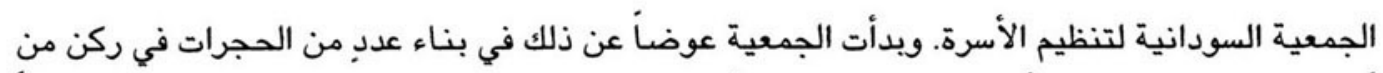

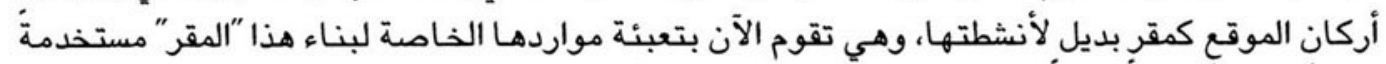

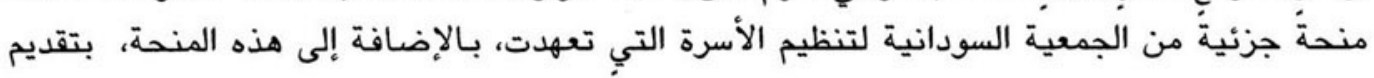

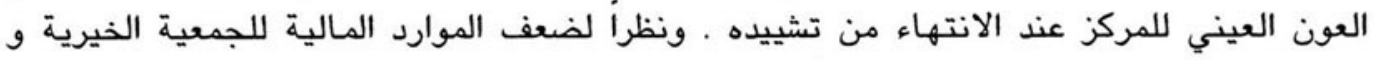

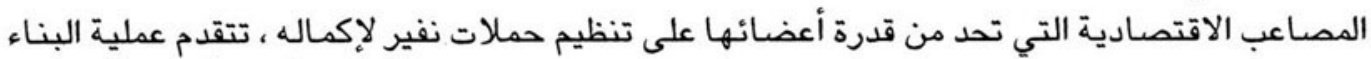
ببطء شديد مما زاد من إحباط الجمعية التي لا تملك حتى هذا الحئ الحين مكتبـاً أو مقراً بديلاً.

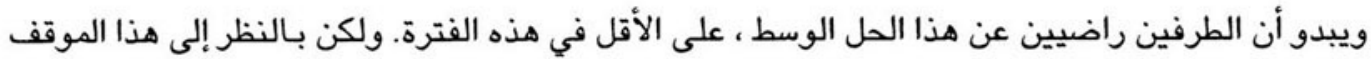

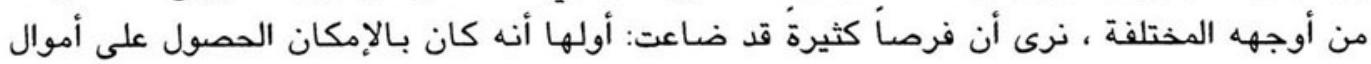

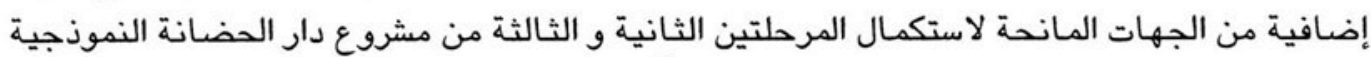

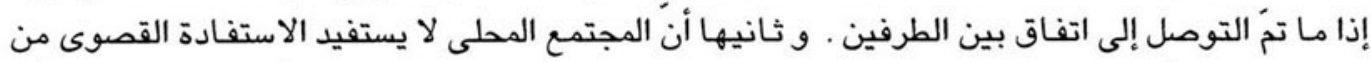

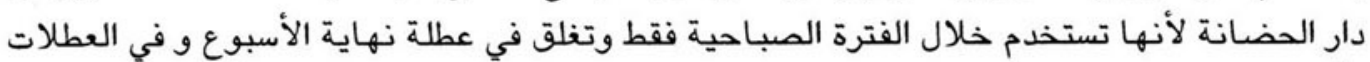

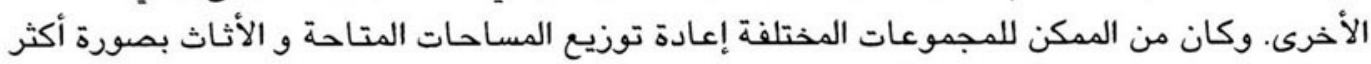

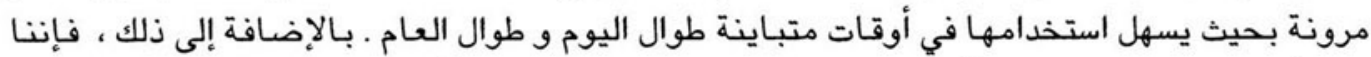

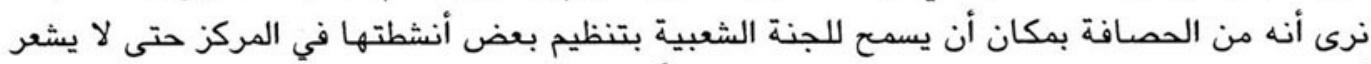

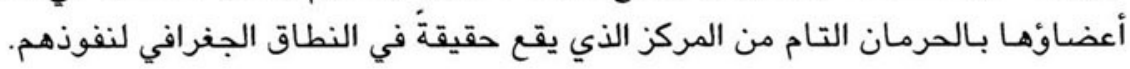

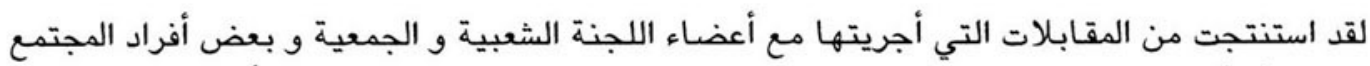

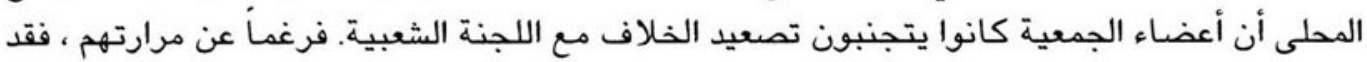

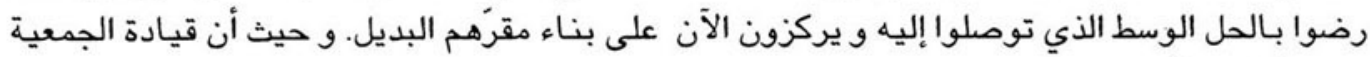

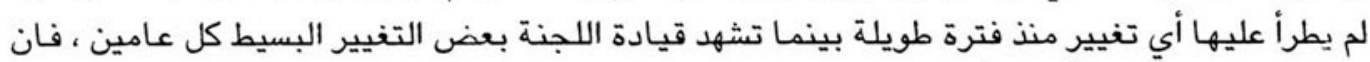

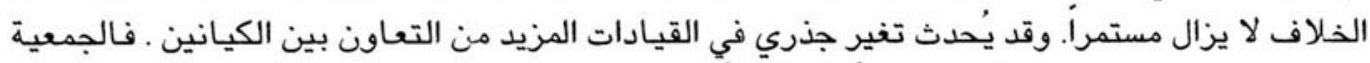

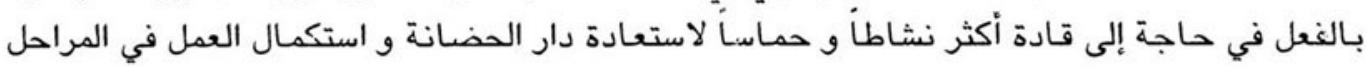

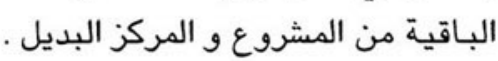

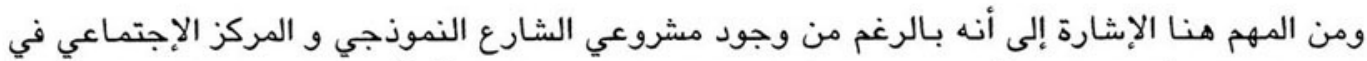

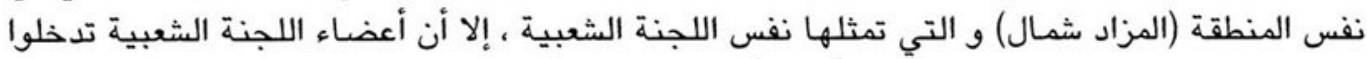

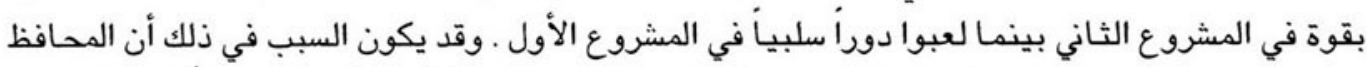

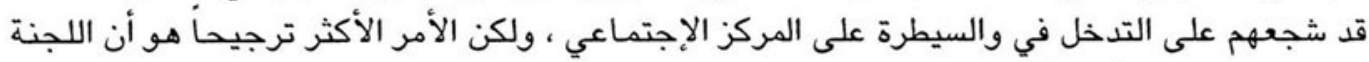

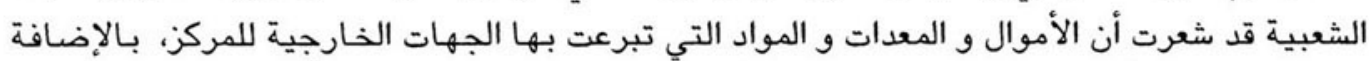

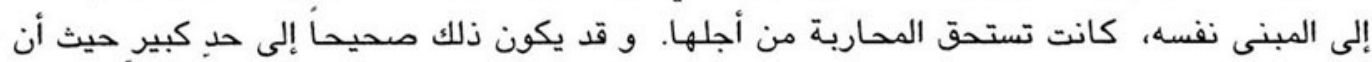
اللجنة الشعبية - ككيان منتخب - هي دائما تحت ضغط مستمر لإظهار منجزاتها. 


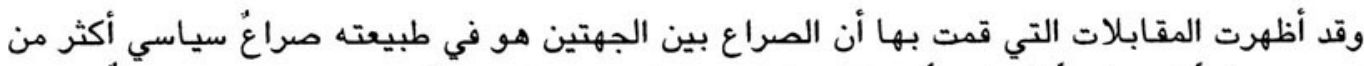

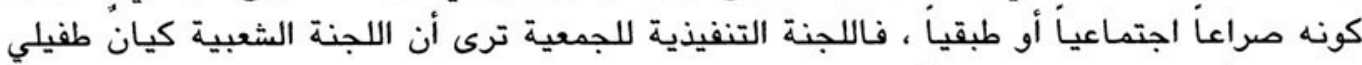

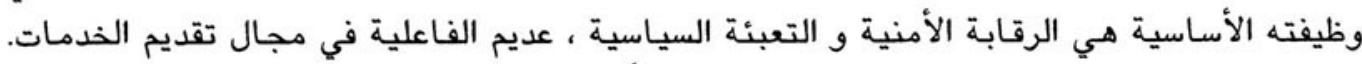

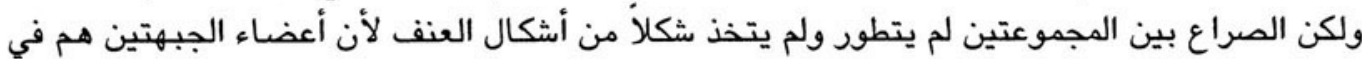

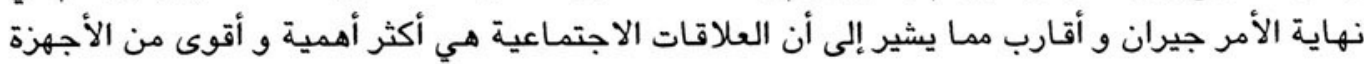

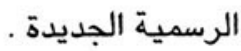

\section{خـامســـا: الخلاصــــة}

إن لامركزية السلطات الإدارية وتوزيعها على السلطات المحلية سمة مشتركة لكافة الحكومات السودانية

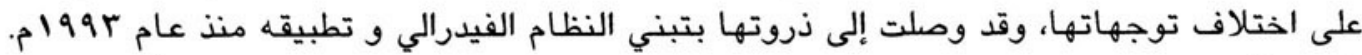

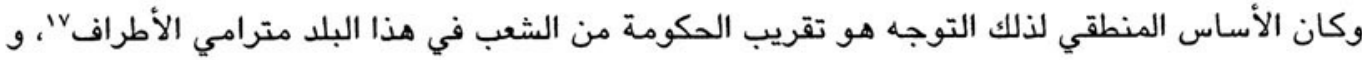

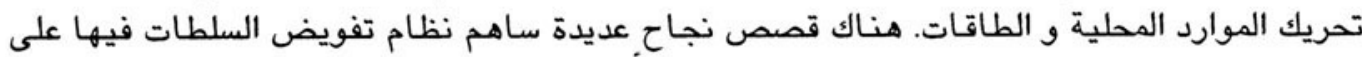

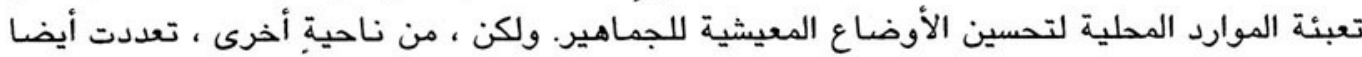

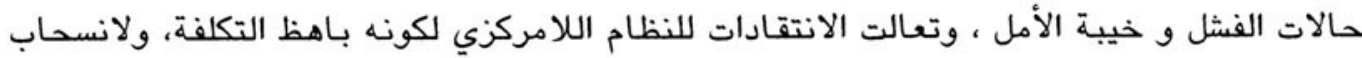

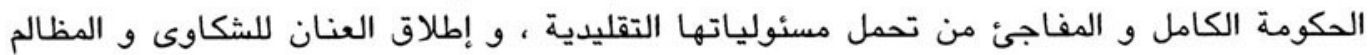

خلق النظام الفيدرالي أجهزةٌ محلية عديدة على مستوى الولايات والمحليات بدون توفير الموارد المالية

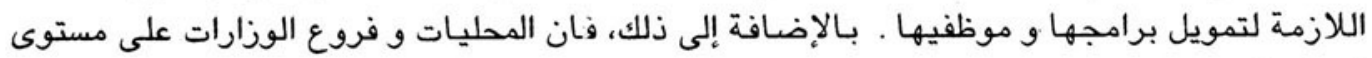

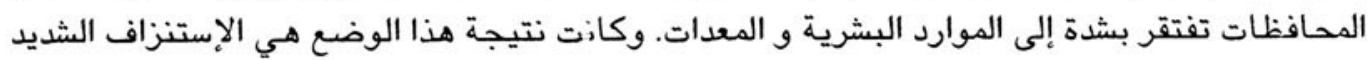

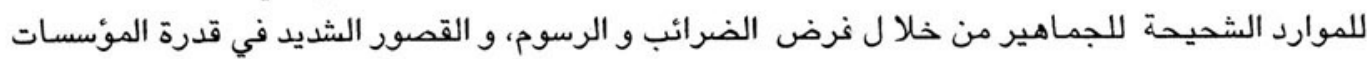

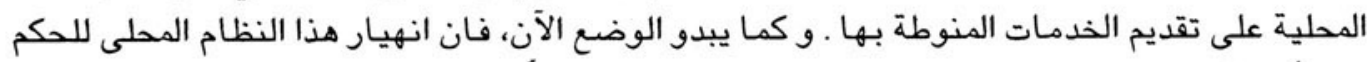

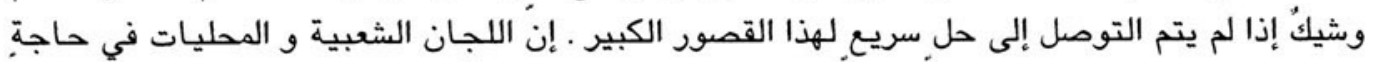

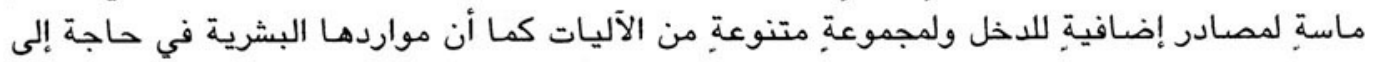
تنمية .

لقد تم فرض الأجهزة الرسمية المحلية ، خاصة اللجان الشعبية ، فوق الأجهزة والمؤسسات الاجتماعية

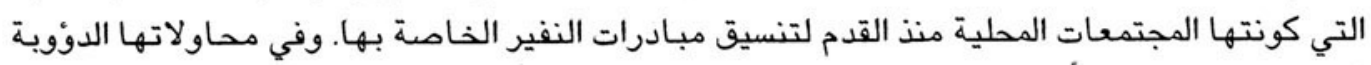

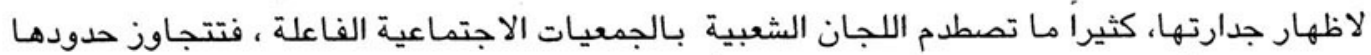

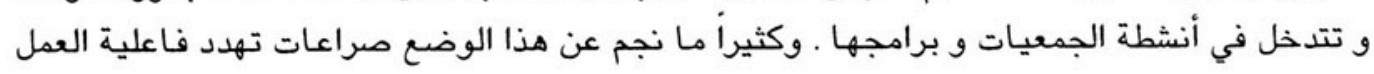




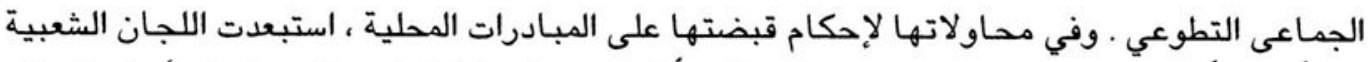

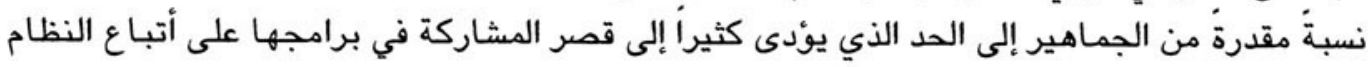
الحاكم فقط.

ويالاضافة إلى التنظيمات الاجتماعية القديمة التي استمرت في العمل حتى بعد تكوين الأجهزة الرسمية

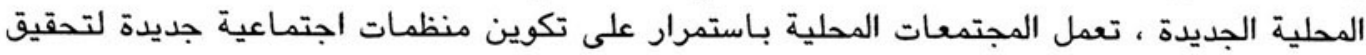

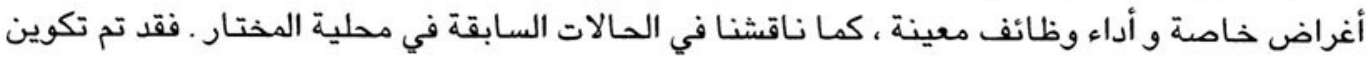

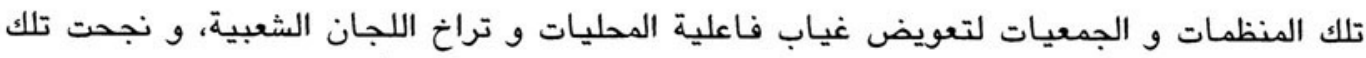

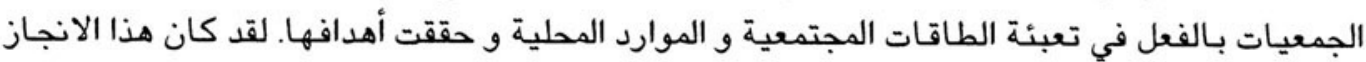

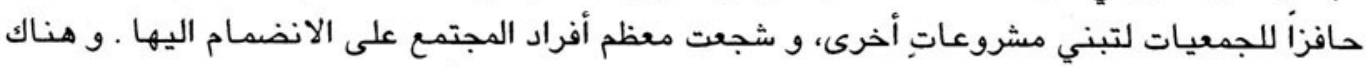

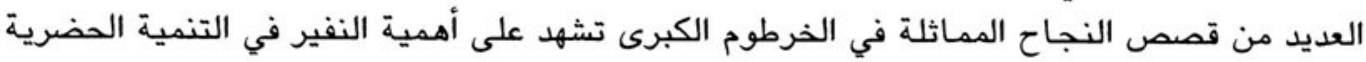

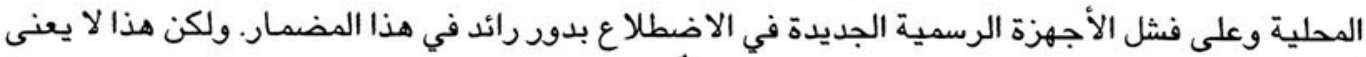

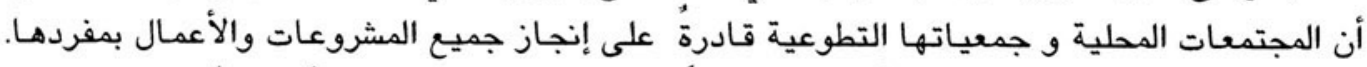

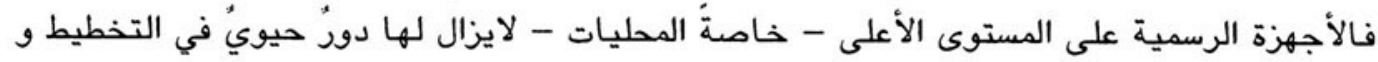
التنسيق و التدريب و توفير المعدات الثقيلة و تنفيذ المشروعات المعقدة و شبكات البنية التحتية

الرئيسية.

وقد تكون اللجان الشعبية ذات فائدة للنظام الحاكم نتيجة للمهام السياسية و الأمنية التي تؤديها، و

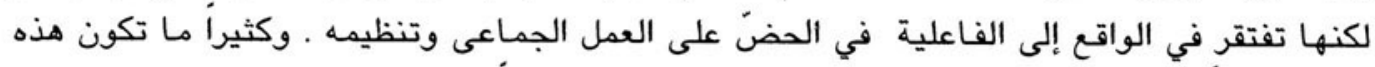

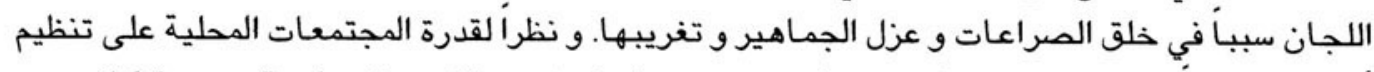

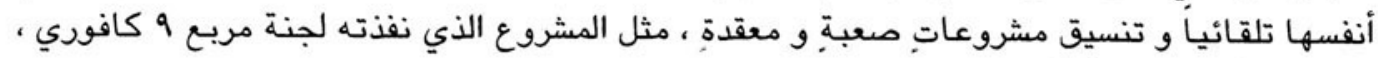
فهناك شكُ في وجود أيَّ دورِ للجان الشعبية في التنمية الحضرية المحلية.

ان النالات الثلاث المشار اليها أعلاه تثير قضايا هـامة تتعلق بـأسلوب الحكم الحضري (governance)

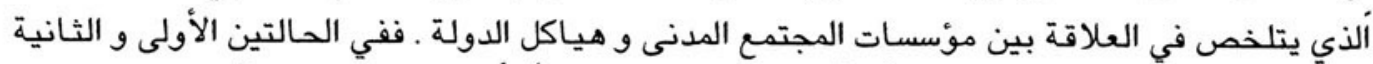

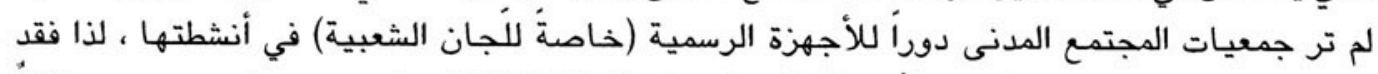

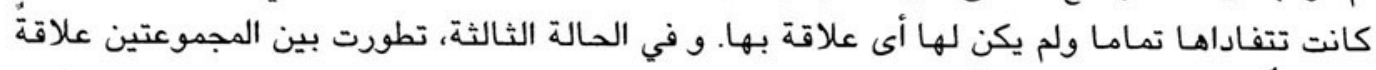

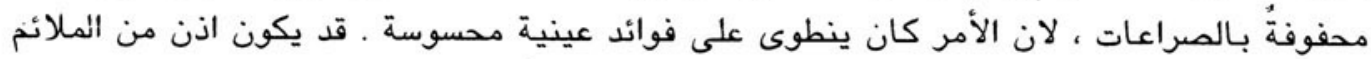

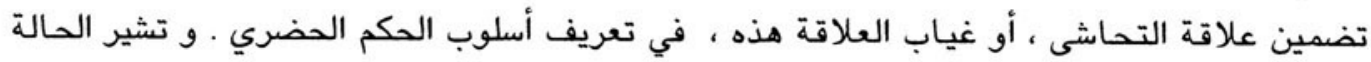

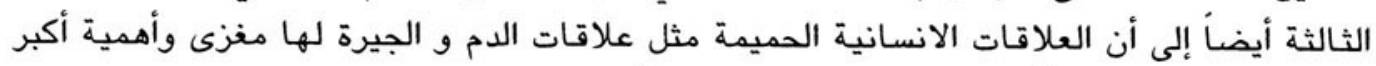
بالنسبة للجماهير من الأجهزة الرسمية المفروضة الإنة من أعلى. 
نأمل أن يتمكن أعضاء المجتمعات المحلية من التغلب على خلافاتهم و العمل معاً ، في نطاق مبادرات

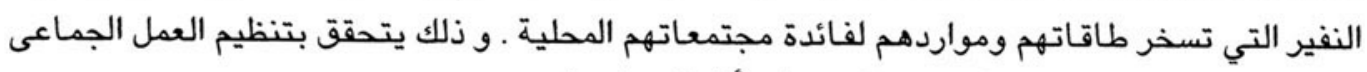
بصورة تعود بالفائدة على الجميع و ليس على أقلى أقلية سياسية محدودة . 


\section{المراجــ}

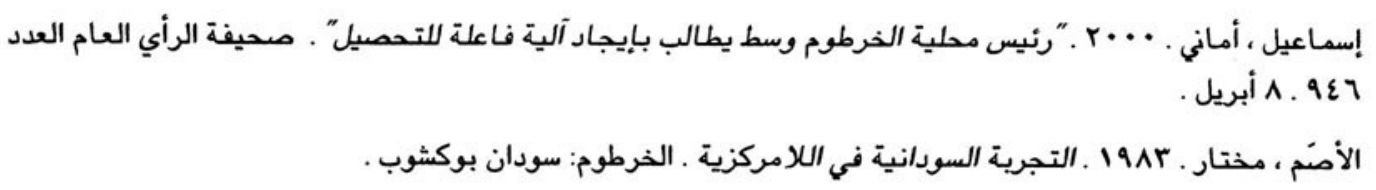
بيات ، آصف 1991 ـ "فقراء القامرة: إستراتيجيات البقاء و شبكات التضامن". في القاهرة في لحظة تحؤل . تحرير

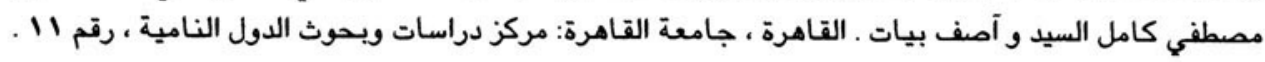

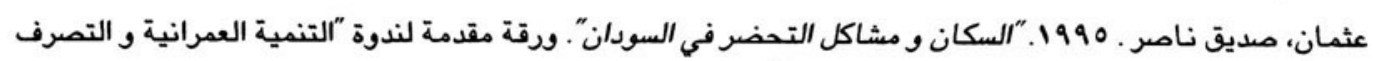

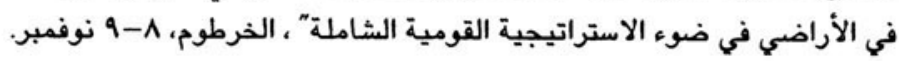

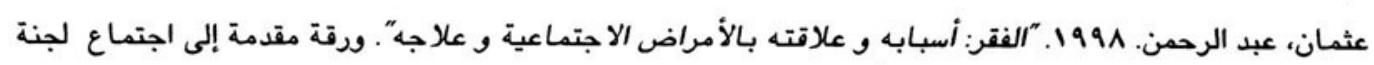

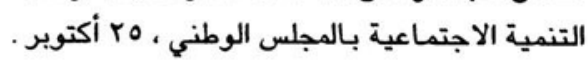

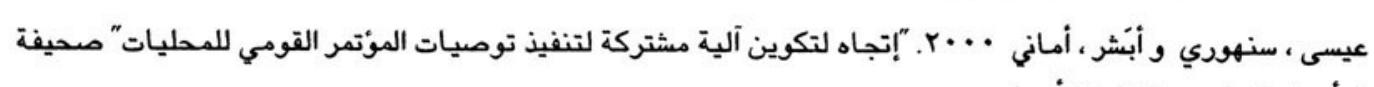

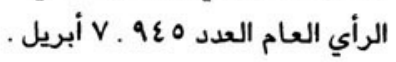

Al-Teraifi, Al-Agab. 1990. Regionalization in Sudan: An Evaluation of the Regional Government Act of 1980. Monograph Series No. 1. Khartoum, Sudan: Council for Studies of Regionalism, University of Khartoum.

Doebele, W.A. 1982. Land Readjustment: A Different Approach to Financing Urban Development. Lexington, Massachusetts: Lexington Books.

Hamid, Gamal M. 1996. Population Displacement in the Sudan: Patterns, Policies, Coping Strategies. Staten Island, New York: Centre for Migration Studies.

McCarney, P. et al. 1995. "Towards an understanding of Governance: The emergence of an idea and its implications for urban research in developing countries". In S ren, R. and Bell, J. (eds.) Urban Research in the Developing World, Volume 4: Perspectives on the City. Toronto: Center for Urban and Community Studies, University of Toronto.

National Population Council, Sudan, 1996. Sudan's Report to the Second United Nations Human Settlements (Habitat II) Conference.

Rondinelli, Dennis. 1981. Decentralization of Development Administration in East Africa: A Review of Experience in Tanzania, Kenya, and the Sudan. Nagoya, Japan: United Nations Center for Regional Development.

United Nations Development Programme. UNDP 1998 Poverty Report: Overcoming Human Poverty. New York, NY: United Nations Publications.

World Bank. 1990. World Development Report 1990. New York, NY: Oxford University Press. 


\section{الهـــوامش}

Hamid, المزيد, من المعلومات عن نشأة مشكلة النزوح السكانى و نتائجها أنظر . 1996

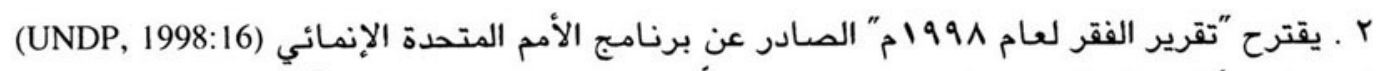

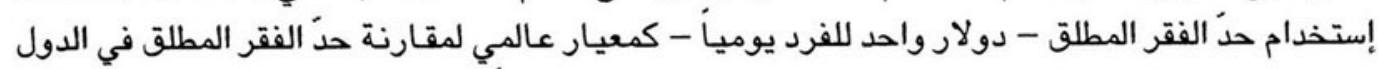

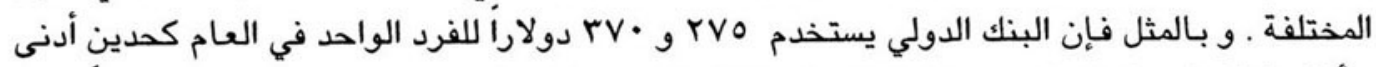

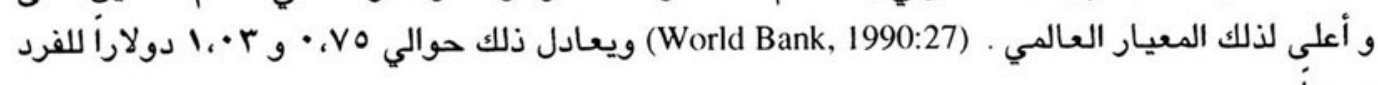
يومياً.

r ـ هذه تقديرات الكاتب على أساس المعلومات المجمَعة من المحليات في عام 1999 م.

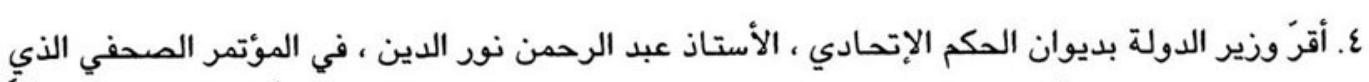

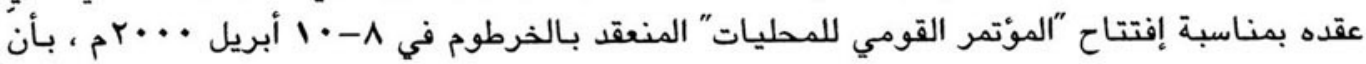

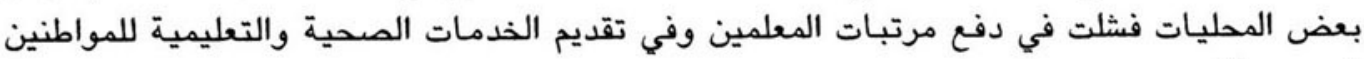

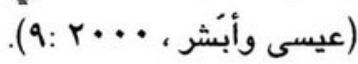

ه . تملك اللجان الشعبية قاعدة بيانات جيدة عن الأفراد الذين يقعون في دائرة نفوذها يمكن من خلالها

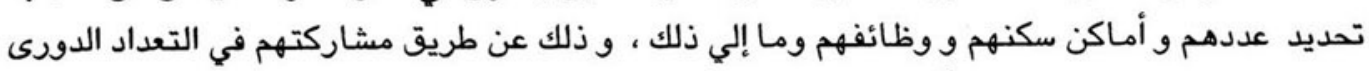

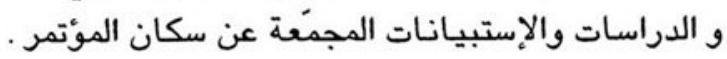
7 ـ ـ تُم رفع الدعم الحكومي عن سلعة السكر في عام 999 ام ـ

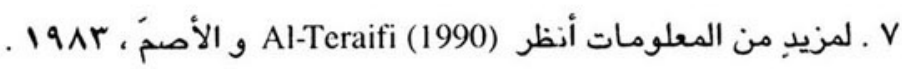
A . السودان هو أكبر دول أفريقيا إذ تفوق مساحته إثنين مليون كيلو متر مربع ، وهي تعادل أكثر من

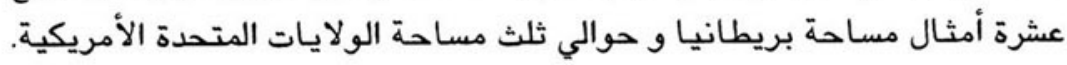

9 ـ ينص الدستور على أن يتشاور الرئيس مع مجلس الولاية لتحديد ثلاثة مرشحين ينتخب من بينهم

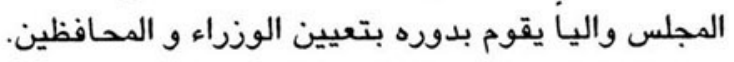

• 1 . في ورقة قدمها للمؤتمر القومي للمحليات أكَّ رئيس محلية الخرطوم أن العديد من المحليات ليست

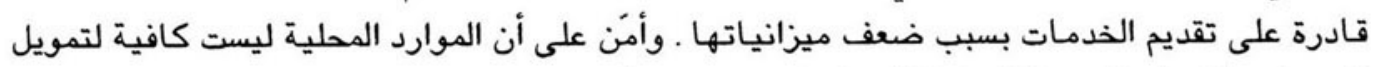

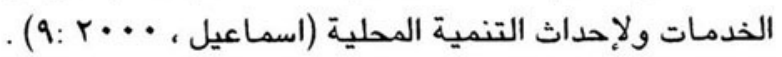

Iا ـ ان السكر من المواد الغذائية شديدة الأهمية في حياة الأسر السودانية . فنظرأ لارتفاع أسعار الفاكهة

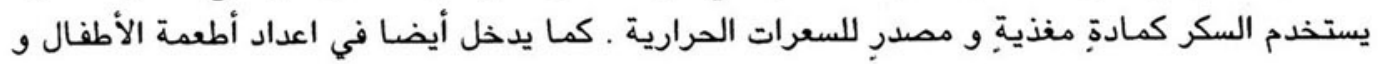


أطباق سودانية كثيرة ، و يضاف إلي الشاى و القهوة واللبن و المشروبات الأخرى التي يشربها معظم

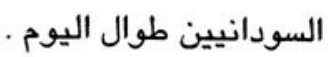

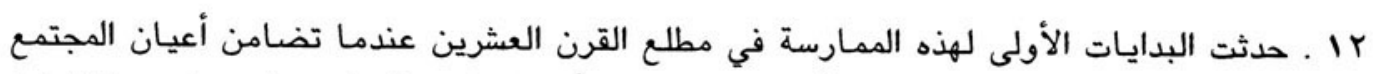

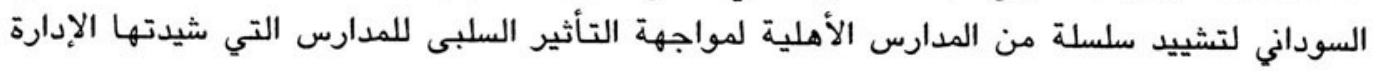
الإستعمارية آنذاك.

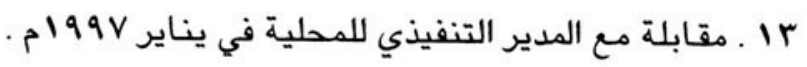
ع ا ـ نظمت وزارة الشئون الهندسية تدابير المشاركة مع المجتمعات المحلية في مجال التنمية الحضرية،

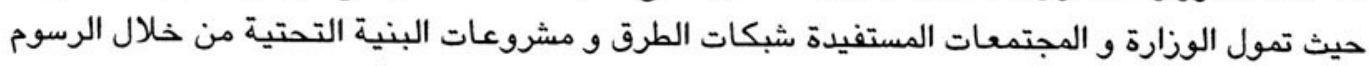

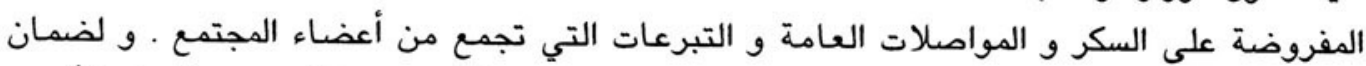

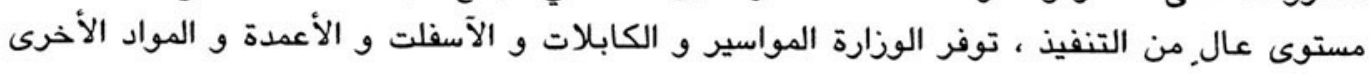
للمجتمعات المعنية نظير مقابل مادي رمزي و تعطى توجيهاتها لمهندسيها للاشراف على التى التنفيذ. 10 ـ ليس من المعتاد أن تشارك النساء في هذا النوع من العمل الجماعى بالرغم من أن كثير منهن يدرسن و يعملن خارج المنزل .

17

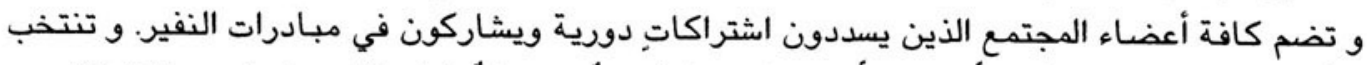

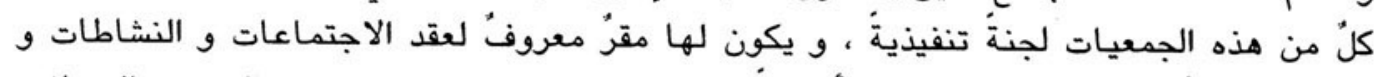

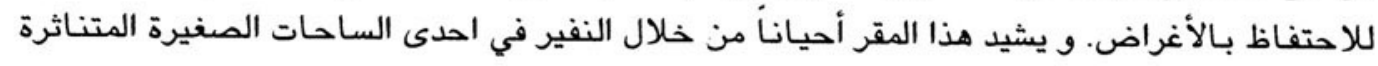
في المناطق الحضرية في الخرطوم الكبرى. V IV الشعار المتدايل هو "تقصير الظل الإداري"؛ 


\begin{abstract}
This study investigates the interactions that take place between formal governmental institutions and informal, popular associations in the arena of local urban development, taking Greater Khartoum as an example. Hence, the essay contributes to the study of urban governance, and assesses the rationale behind administrative decentralization and its concomitant repercussions on urban development.

At first, the various attempts at decentralizing administrative authority in Sudan are explored. Two conclusions are deduced from the most recent decentralization experience (i.e. federalism). First, the newly-created formal structures were not provided with sufficient financial resources and trained personnel, hence, they have not been successful in fulfilling their mandates. Second, these structures have been superimposed over extant popular associations that have similar mandates, often leading to duplication of efforts and conflict.
\end{abstract}

The essay presents three cases of local urban development, initiated by local communities in response to the ineffectiveness of formal institutions. They illustrate the various forms of interactions (cooperative, exclusionary or antagonistic) that resulted from the superimposition of new, ineffective formal structures over dynamic popular ones. In these cases, information institutions have managed to mobilize the resources of their members and implement urban development schemes. This may point the way to tackling local urban development, especially when the formal institutions play a supportive and coordinating role. 


\title{
Local Level Authorities and Local Action in Greater Khartoum, Sudan
}

\author{
Gamal M. Hamid*
}

* Gamal Mahmoud Hamid holds a bachelor of architecture from the University of Khartoum, a masters of architecture studies from the Massachusetts Institute of Technology and a Ph.D in urban planning from the University of California, Los Angeles. He teaches at the University of Khartoum. 


$$
\begin{aligned}
& \text { مجلس السكان الدولى } \\
& \text { صندوق بريد } 110 \\
& \text { الدقى ، القاهرة } \\
& \text { جمهورية مصر العربية القرة }
\end{aligned}
$$

